Supporting Information

\title{
Total Synthesis of (+)-CC-1065 Utilizing Ring Expansion Reaction of Benzocyclobutenone Oxime Sulfonate
}

Taku Imaizumi, Yumi Yamashita, Yuki Nakazawa, Kentaro Okano, Juri Sakata, Hidetoshi Tokuyama*

Graduate School of Pharmaceutical Sciences, Tohoku University, Aoba 6-3, Aramaki, Aoba-ku, Sendai 980-8578, Japan

* tokuyama@mail.pharm.tohoku.ac.jp 


\section{Table of Contents}

General Remarks

Experimental Procedures

${ }^{1} \mathrm{H}-\mathrm{NMR}$ and ${ }^{13} \mathrm{C}-\mathrm{NMR}$ spectra
$\mathrm{S}-2$

S-3

S-21

\section{General Remarks}

All moisture or air sensitive reactions were carried out under a positive atmosphere of argon in oven-dried glassware. Commercial reagents were obtained from commercial suppliers and used without further purification unless otherwise mentioned. Toluene, DMF, DMSO, pyridine, and $\mathrm{Et}_{3} \mathrm{~N}$ were distilled from $\mathrm{CaH}_{2}$. Anhydrous $\mathrm{THF}, \mathrm{Et}_{2} \mathrm{O}, \mathrm{MeCN}$, and $\mathrm{CH}_{2} \mathrm{Cl}_{2}$ were purchased from KANTO CHEMICAL CO., INC. Flash column chromatography was performed on Silica Gel 60N (neutral, 40-50 $\mu \mathrm{m}$ ) using the indicated eluent. Preparative TLC and analytical TLC were performed on Merck $60 \mathrm{~F}_{254}$ glass plates precoated with a $0.25 \mathrm{~mm}$ thickness of silica gel. NMR spectra were recorded on a JNM-AL400 spectrometer. Chemical shifts are expressed in parts per million (ppm) downfield from internal standard (tetramethylsilane, $0.00 \mathrm{ppm}$ ), and coupling constants $(J)$ are reported as hertz $(\mathrm{Hz})$. Splitting patterns are indicated as follows: $\mathrm{s}=$ singlet, $\mathrm{d}=$ doublet, $\mathrm{t}=$ triplet, $\mathrm{m}=$ multiplet, $\mathrm{br}=$ broad. IR spectra were measured on a SHIMADZU FTIR8300 spectrometer. High-resolution mass spectra (HRMS) were measured on a Bruker micrOTOF II (ESI). Optical rotations were measured on a JASCO P-2200. Melting point determinations were performed by using a Yanaco MP-500 instrument. 


\section{Oxime S2}

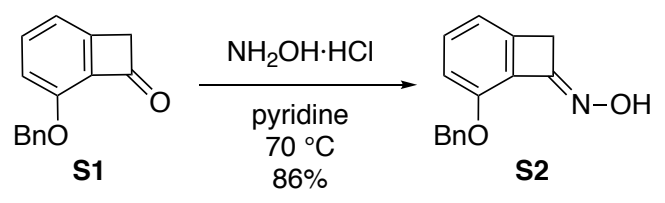

To a solution of ketone $\mathbf{S 1}^{1}(721 \mathrm{mg}, 3.22 \mathrm{mmol})$ in pyridine $(6.4 \mathrm{~mL})$ was added hydroxylamine hydrochloride $(557 \mathrm{mg}, 8.02 \mathrm{mmol})$ at room temperature. After stirring at $70{ }^{\circ} \mathrm{C}$ for $5 \mathrm{~h}$, the reaction was quenched with $2 \mathrm{M}$ aqueous $\mathrm{HCl}$, and the mixture was extracted with EtOAc three times. The combined organic extracts were washed with $2 \mathrm{M}$ aqueous $\mathrm{HCl}$ and brine, dried over anhydrous sodium sulfate, and filtered. The organic solvents were removed under reduced pressure to give a crude material, which was purified by trituration (hexanes) to afford oxime S2 (687 mg, $2.87 \mathrm{mmol}, 86 \%$ ). A yellow solid; mp 135-137 ${ }^{\circ} \mathrm{C}$ (hexanes-EtOAc, colorless prisms); IR (film): 3308, 1583, 1480, 1455, 1384, 1267, 1166, 1064, 977, 922, 784, 765, 723, $698 \mathrm{~cm}^{-1} ;{ }^{1} \mathrm{H}$ NMR (400 MHz, $\left.\mathrm{CDCl}_{3}\right): \delta 7.43(\mathrm{~d}, 2 \mathrm{H}, J=7.2 \mathrm{~Hz}), 7.40-7.18(\mathrm{~m}, 4 \mathrm{H}), 6.90-6.78(\mathrm{~m}, 2 \mathrm{H}), 5.42$ $(\mathrm{s}, 2 \mathrm{H}), 3.86(\mathrm{~s}, 2 \mathrm{H}) ;{ }^{13} \mathrm{C} \mathrm{NMR}\left(100 \mathrm{MHz}, \mathrm{CDCl}_{3}\right): \delta 153.2,151.7,145.1,136.9,133.4,128.4$, 127.9, 127.6, 125.3, 116.1, 115.5, 72.0, 38.0; HRMS (ESI) $m / z$ : calcd. for $\mathrm{C}_{15} \mathrm{H}_{14} \mathrm{NO}_{2} 240.1019$ $\left[\mathrm{M}+\mathrm{H}^{+}\right]$found 240.1029 .

\section{Sulfonate 22a}

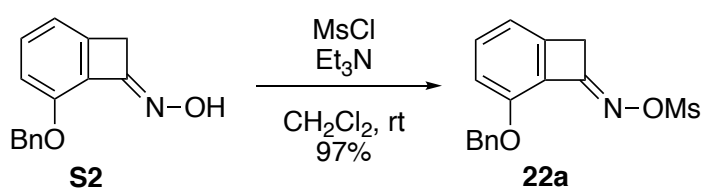

To a solution of oxime $\mathbf{S 2}(27.8 \mathrm{mg}, 116 \mu \mathrm{mol})$ and $\mathrm{MsCl}(22.5 \mu \mathrm{L}, 290 \mu \mathrm{mol})$ in $\mathrm{CH}_{2} \mathrm{Cl}_{2}$ $(0.58 \mathrm{~mL})$ was added $\mathrm{Et}_{3} \mathrm{~N}(97.0 \mu \mathrm{L}, 697 \mu \mathrm{mol})$ at room temperature. After stirring at room temperature for $1 \mathrm{~h}$, the reaction was quenched with $1 \mathrm{M}$ aqueous $\mathrm{HCl}$, and the mixture was extracted with EtOAc three times. The combined organic extracts were washed with $1 \mathrm{M}$ aqueous $\mathrm{HCl}$ and brine, dried over anhydrous sodium sulfate, and filtered. The organic solvents were removed under reduced pressure to give a crude material, which was purified by preparative TLC (hexanes-EtOAc = 3:1) to afford sulfonate 22a $(35.7 \mathrm{mg}, 112 \mu \mathrm{mol}, 97 \%)$. A yellow amorphous; IR (film): 2917, 2849, 1598, 1480, 1367, 1278, 1183, 837, $747 \mathrm{~cm}^{-1} ;{ }^{1} \mathrm{H}$ NMR (400 MHz, $\left.\mathrm{CDCl}_{3}\right)$ : $\delta 7.44-7.31(\mathrm{~m}, 6 \mathrm{H}), 6.19-6.88(\mathrm{~m}, 2 \mathrm{H}), 5.43(\mathrm{~s}, 2 \mathrm{H}), 3.98(\mathrm{~s}, 2 \mathrm{H}), 3.17(\mathrm{~s}, 3 \mathrm{H}) ;{ }^{13} \mathrm{C} \mathrm{NMR}(100$ $\left.\mathrm{MHz}, \mathrm{CDCl}_{3}\right): \delta 161.0,145.2,136.4,136.2,128.6,128.2,127.5,122.3,116.9,115.7,114.2,72.1$, 39.6, 36.4; HRMS (ESI) $m / z$ : calcd. for $\mathrm{C}_{16} \mathrm{H}_{15} \mathrm{NNaO}_{4} \mathrm{~S} 340.0614\left[\mathrm{M}+\mathrm{Na}^{+}\right]$found 340.0599 .

\section{Sulfonate 22b}

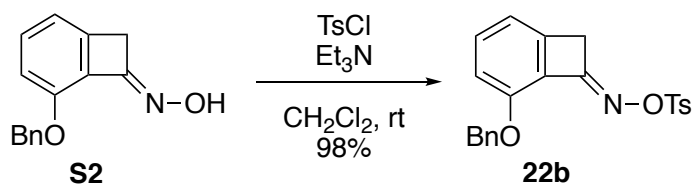

To a solution of oxime $\mathbf{S 2}(15.0 \mathrm{mg}, 62.7 \mu \mathrm{mol})$ and $\mathrm{TsCl}(30.0 \mathrm{mg}, 157 \mu \mathrm{mol})$ in $\mathrm{CH}_{2} \mathrm{Cl}_{2}$ $(2.0 \mathrm{~mL})$ was added $\mathrm{Et}_{3} \mathrm{~N}(100 \mu \mathrm{L}, 700 \mu \mathrm{mol})$ at room temperature. After stirring at room 
temperature for $1 \mathrm{~h}$, the reaction was quenched with $1 \mathrm{M}$ aqueous $\mathrm{HCl}$, and the mixture was extracted with EtOAc three times. The combined organic extracts were washed with $1 \mathrm{M}$ aqueous $\mathrm{HCl}$ and brine, dried over anhydrous sodium sulfate, and filtered. The organic solvents were removed under reduced pressure to give a crude material, which was purified by preparative TLC (hexanes-EtOAc $=3: 1)$ to afford sulfonate $\mathbf{2 2 b}(23.9 \mathrm{mg}, 61.2 \mu \mathrm{mol}, 98 \%)$. A colorless amorphous; IR (film): 1595, 1478, 1373, 1277, 1456, 1376, 1157, 1094, 833, 750, $664 \mathrm{~cm}^{-1} ;{ }^{1} \mathrm{H}$ NMR (400 $\left.\mathrm{MHz}, \mathrm{CDCl}_{3}\right): \delta 7.86(\mathrm{~d}, 2 \mathrm{H}, J=8.4 \mathrm{~Hz}), 7.37-7.22(\mathrm{~m}, 8 \mathrm{H}), 6.85-6.82(\mathrm{~m}, 2 \mathrm{H}), 5.30(\mathrm{~s}, 2 \mathrm{H}), 3.91$ (s, 2H), $2.34(\mathrm{~s}, 3 \mathrm{H}) ;{ }^{13} \mathrm{C}$ NMR $\left(100 \mathrm{MHz}, \mathrm{CDCl}_{3}\right): \delta 159.9,152.8,145.0,136.5,135.8,132.5$, 129.5, 129.0, 128.5, 128.1, 127.6, 127.0, 122.4, 117.3, 115.5, 72.3, 39.4, 21.6; HRMS (ESI) $\mathrm{m} / \mathrm{z}$ : calcd. for $\mathrm{C}_{22} \mathrm{H}_{20} \mathrm{NO}_{4} \mathrm{~S} 394.1108\left[\mathrm{M}+\mathrm{H}^{+}\right]$found 394.1124.

\section{Sulfonate 22c}

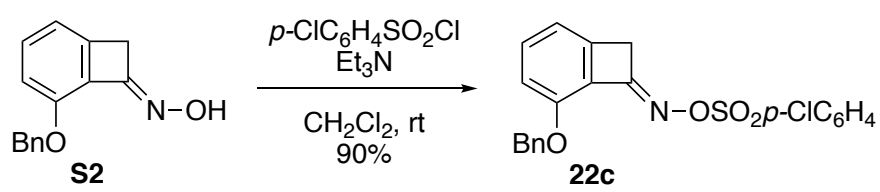

To a solution of oxime $\mathbf{S 2}(102 \mathrm{mg}, 424 \mu \mathrm{mol})$ and $p-\mathrm{ClC}_{6} \mathrm{H}_{4} \mathrm{SO}_{2} \mathrm{Cl}(229 \mathrm{mg}, 1.08 \mathrm{mmol})$ in $\mathrm{CH}_{2} \mathrm{Cl}_{2}(4.2 \mathrm{~mL})$ was added $\mathrm{Et}_{3} \mathrm{~N}(360 \mu \mathrm{L}, 2.55 \mathrm{mmol})$ at room temperature. After stirring at room temperature for $22 \mathrm{~h}$, the reaction was quenched with $1 \mathrm{M}$ aqueous $\mathrm{HCl}$, and the mixture was extracted with EtOAc three times. The combined organic extracts were washed with $1 \mathrm{M}$ aqueous $\mathrm{HCl}$ and brine, dried over anhydrous sodium sulfate, and filtered. The organic solvents were removed under reduced pressure to give a crude material, which was purified by silica gel column chromatography (hexanes- $\mathrm{CH}_{2} \mathrm{Cl}_{2}=2: 3$ ) to afford sulfonate $22 \mathrm{c}(158 \mathrm{mg}, 382 \mu \mathrm{mol}, 90 \%)$. A colorless solid; mp $97-99^{\circ} \mathrm{C}$ (hexanes-EtOAc, colorless prisms); IR (film): 1586, 1558, 1475, 1456, 1376, 1279, 1191, 830, 757, 615, $\left.549 \mathrm{~cm}^{-1} ;{ }^{1} \mathrm{H} \mathrm{NMR} \mathrm{(400} \mathrm{MHz,} \mathrm{CDCl}_{3}\right): \delta 7.89$ (d, 2H, $\left.J=8.8 \mathrm{~Hz}\right)$, 7.42-7.27 (m, 8H), 6.87-6.78 (m, 2H), $5.28(\mathrm{~s}, 2 \mathrm{H}), 3.90(\mathrm{~s}, 2 \mathrm{H}) ;{ }^{13} \mathrm{C} \mathrm{NMR}\left(100 \mathrm{MHz}, \mathrm{CDCl}_{3}\right): \delta$ $160.3,152.8,145.0,140.7,136.2$, 136.0, 133.8, 130.4, 129.2, 128.5, 128.2, 127.5, 122.1, 117.1, 115.5, 72.2, 39.4; HRMS (ESI) $\mathrm{m} / z$ : calcd. for $\mathrm{C}_{21} \mathrm{H}_{17} \mathrm{ClNO}_{4} \mathrm{~S} 414.0561\left[\mathrm{M}+\mathrm{H}^{+}\right]$found 414.0551 .

\section{Sulfonate 22d}
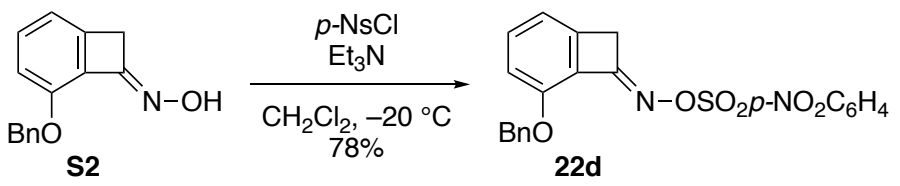

To a solution of oxime $\mathbf{S 2}(99.4 \mathrm{mg}, 415 \mu \mathrm{mol})$ and $p$ - $\mathrm{NsCl}(110 \mathrm{mg}, 496 \mu \mathrm{mol})$ in $\mathrm{CH}_{2} \mathrm{Cl}_{2}$ $(4.2 \mathrm{~mL})$ was added $\mathrm{Et}_{3} \mathrm{~N}(160 \mu \mathrm{L}, 1.18 \mathrm{mmol})$ at $-20{ }^{\circ} \mathrm{C}$. After stirring at $-20{ }^{\circ} \mathrm{C}$ for $15 \mathrm{~min}$, the reaction was quenched with $1 \mathrm{M}$ aqueous $\mathrm{HCl}$, and the mixture was extracted with EtOAc three times. The combined organic extracts were washed with $1 \mathrm{M}$ aqueous $\mathrm{HCl}$ and brine, dried over anhydrous sodium sulfate, and filtered. The organic solvents were removed under reduced pressure to give a crude material, which was purified by flash silica gel column chromatography (hexanes- $\mathrm{CH}_{2} \mathrm{Cl}_{2}=1: 1$ ) to afford sulfonate $22 \mathrm{~d}$ (138 mg, $324 \mu \mathrm{mol}, 78 \%$ ). A colorless solid; mp 156- $157^{\circ} \mathrm{C}$ (hexanes-EtOAc, colorless prisms); IR (film): 1535, 1382, 1348, 1192, 1173, 854, 737, 
678, 594, $563 \mathrm{~cm}^{-1} ;{ }^{1} \mathrm{H}$ NMR (400 MHz, $\left.\mathrm{CDCl}_{3}\right): \delta 8.25(\mathrm{~d}, 2 \mathrm{H}, J=6.8 \mathrm{~Hz}), 8.14(\mathrm{~d}, 2 \mathrm{H}, J=6.8$ $\mathrm{Hz}), 7.40-7.30(\mathrm{~m}, 6 \mathrm{H}), 6.88(\mathrm{~d}, 1 \mathrm{H}, J=7.6 \mathrm{~Hz}), 6.85(\mathrm{~d}, 1 \mathrm{H}, J=8.8 \mathrm{~Hz}), 5.26(\mathrm{~s}, 2 \mathrm{H}), 3.95(\mathrm{~s}$, $2 \mathrm{H}) ;{ }^{13} \mathrm{C}$ NMR $\left(100 \mathrm{MHz}, \mathrm{CDCl}_{3}\right): \delta 161.0,153.0,150.8,145.0,141.1,136.4,136.1,130.4,128.7$, $128.5,127.5,124.0,121.9,117.0,115.7,72.2$, 39.6; HRMS (ESI) $m / z$ : calcd. for $\mathrm{C}_{21} \mathrm{H}_{16} \mathrm{~N}_{2} \mathrm{NaO}_{6} \mathrm{~S}$ $447.0621\left[\mathrm{M}+\mathrm{Na}^{+}\right]$found 447.0623 .

Indole 23

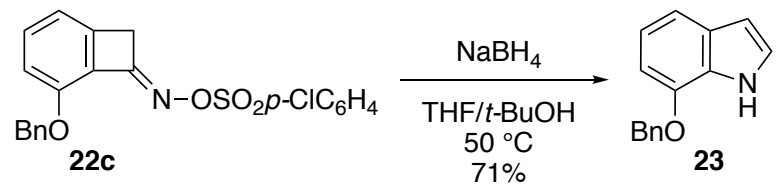

To a solution of sulfonate $22 \mathrm{c}(20.7 \mathrm{mg}, 50.0 \mu \mathrm{mol})$ in THF $(0.4 \mathrm{~mL})$ and $t$-BuOH $(0.1 \mathrm{~mL})$ was added $\mathrm{NaBH}_{4}(18.7 \mathrm{mg}, 494 \mu \mathrm{mol})$ at room temperature. After stirring at $50{ }^{\circ} \mathrm{C}$ for $11 \mathrm{~h}$, the reaction was quenched with $\mathrm{H}_{2} \mathrm{O}$, and the mixture was extracted with EtOAc three times. The combined organic extracts were washed with brine, dried over anhydrous sodium sulfate, and filtered. The organic solvents were removed under reduced pressure to give a crude material, which was purified by preparative TLC (hexanes- $\mathrm{CHCl}_{3}=1: 1$ ) to afford indole 23 (7.90 $\mathrm{mg}, 35.3 \mu \mathrm{mol}$, 71\%). A colorless solid; mp 58-60 ${ }^{\circ} \mathrm{C}$ (hexanes-EtOAc, colorless prisms); IR (film): 3432, 1578, 1490, 1415, 1339, 1288, 1253, 1067, 783, $724 \mathrm{~cm}^{-1} ;{ }^{1} \mathrm{H}$ NMR (400 MHz, $\left.\mathrm{CDCl}_{3}\right): \delta 8.35$ (br s, $\left.1 \mathrm{H}\right)$, $7.46(\mathrm{~d}, 1 \mathrm{H}, J=6.8 \mathrm{~Hz}), 7.43-7.30(\mathrm{~m}, 4 \mathrm{H}), 7.27(\mathrm{~d}, 1 \mathrm{H}, J=7.6 \mathrm{~Hz}), 7.12(\mathrm{dd}, 1 \mathrm{H}, J=2.4,2.4 \mathrm{~Hz})$, $7.01(\mathrm{dd}, 1 \mathrm{H}, J=7.6,7.6 \mathrm{~Hz}), 6.70(\mathrm{~d}, 1 \mathrm{H}, J=7.6 \mathrm{~Hz}), 6.52(\mathrm{dd}, 1 \mathrm{H}, J=2.4,2.4 \mathrm{~Hz}), 5.18(\mathrm{~s}, 2 \mathrm{H})$; ${ }^{13} \mathrm{C}$ NMR (100 MHz, $\left.\mathrm{CDCl}_{3}\right): \delta 145.4,137.1,129.3,128.6,128.1,127.8,126.5,123.7,120.1,113.6$, 102.9, 102.8, 70.1; HRMS (ESI) $m / z$ : calcd. for $\mathrm{C}_{15} \mathrm{H}_{14} \mathrm{NO} 224.1070\left[\mathrm{M}+\mathrm{H}^{+}\right]$found 224.1073. Spectroscopic data were identical with those previously reporetd. ${ }^{2}$

\section{Benzonitrile 24}

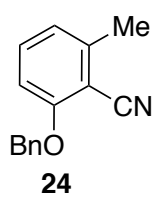

Mp 118-120 ${ }^{\circ} \mathrm{C}$ (hexanes-EtOAc, colorless prisms); IR (film): 2222, 1597, 1580, 1473, 1453, 1289, 1092, 1065, 776, $736 \mathrm{~cm}^{-1}$; ${ }^{1} \mathrm{H} \mathrm{NMR}\left(400 \mathrm{MHz}, \mathrm{CDCl}_{3}\right): \delta 7.47$ (d, 2H, $\left.J=7.6 \mathrm{~Hz}\right), 7.41-$ $-7.37(\mathrm{~m}, 2 \mathrm{H}), 7.34(\mathrm{~d}, 2 \mathrm{H}, J=7.6 \mathrm{~Hz}), 6.87(\mathrm{~d}, 1 \mathrm{H}, J=7.6 \mathrm{~Hz}), 6.81(\mathrm{~d}, 1 \mathrm{H}, J=8.4 \mathrm{~Hz}), 5.20(\mathrm{~s}$, 2H), 2.52 (s, 3H); ${ }^{13} \mathrm{C}$ NMR (100 MHz, $\left.\mathrm{CDCl}_{3}\right): \delta 160.6,144.0,135.8,133.4,128.7,128.1,126.9$, 122.3, 115.6, 109.8, 103.0, 70.5, 20.5; HRMS (EI) $m / z$ : calcd. for $\mathrm{C}_{15} \mathrm{H}_{13} \mathrm{NO} 223.0997\left[\mathrm{M}^{+}\right]$found 223.0981 . 
Indole 25

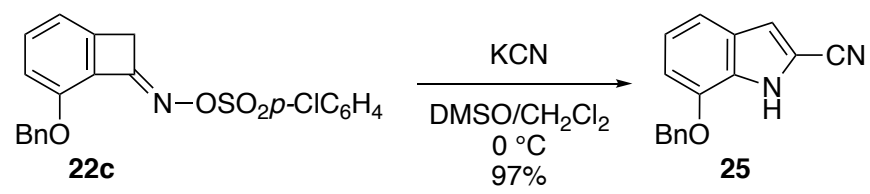

To a solution of sulfonate $22 \mathrm{c}(22.2 \mathrm{mg}, 53.6 \mu \mathrm{mol})$ in DMSO $(0.40 \mathrm{~mL})$ and $\mathrm{CH}_{2} \mathrm{Cl}_{2}(0.13$ $\mathrm{mL})$ was added potassium cyanide $(34.9 \mathrm{mg}, 536 \mu \mathrm{mol})$ at $0{ }^{\circ} \mathrm{C}$. After stirring at $0{ }^{\circ} \mathrm{C}$ for $1 \mathrm{~h}$, the reaction was quenched with $\mathrm{H}_{2} \mathrm{O}$, and the mixture was extracted with EtOAc three times. The combined organic extracts were washed with brine, dried over anhydrous sodium sulfate, and filtered. The organic solvents were removed under reduced pressure to give a crude material, which was purified by preparative TLC (hexanes-EtOAc = 3:1) to afford indole 25 (12.7 $\mathrm{mg}, 51.1 \mu \mathrm{mol}$, 95\%). A colorless solid; mp 110-112 ${ }^{\circ} \mathrm{C}$ (hexanes-EtOAc, colorless prisms); IR (film): 3308,2227 , 1582, 1530, 1497, 1406, 1326, 1259, 1238, 1089, 812, 735, 696, 645, $583 \mathrm{~cm}^{-1} ;{ }^{1} \mathrm{H}$ NMR (400 $\mathrm{MHz}, \mathrm{CDCl}_{3}$ ): $\delta 8.90$ (br s, 1H), 7.46-7.33 (m, 5H), 7.24 (d, 1H, $\left.J=8.4 \mathrm{~Hz}\right), 7.11(\mathrm{~d}, 1 \mathrm{H}, J=2.4$ $\mathrm{Hz}), 7.09(\mathrm{dd}, 1 \mathrm{H}, J=8.4,8.4 \mathrm{~Hz}), 6.82(\mathrm{~d}, 1 \mathrm{H}, J=7.6 \mathrm{~Hz}), 5.18(\mathrm{~s}, 2 \mathrm{H}) ;{ }^{13} \mathrm{C} \mathrm{NMR}(100 \mathrm{MHz}$, $\left.\mathrm{CDCl}_{3}\right): \delta 145.3,136.3,128.8,128.5,128.3,127.9,127.5,122.3,114.46,114.45,113.9,106.2$, 106.0, 70.5; HRMS (ESI) $m / z$ : calcd. for $\mathrm{C}_{16} \mathrm{H}_{12} \mathrm{~N}_{2} \mathrm{NaO} 271.0842\left[\mathrm{M}+\mathrm{Na}^{+}\right]$found 271.0845.

\section{Bis-acetal 27}
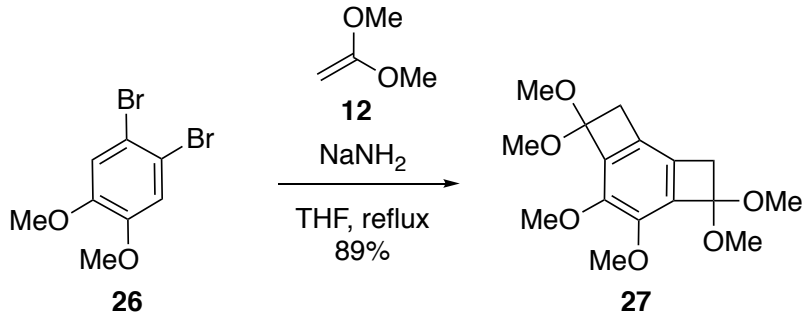

To a solution of $\mathbf{2 6}^{3}(1.30 \mathrm{~g}, 4.40 \mathrm{mmol})$ and ketene dimethyl acetal $\mathbf{1 2}^{4}$ (2.09 $\mathrm{mL}, 22.0$ $\mathrm{mmol})$ in THF $(13 \mathrm{~mL})$ was added sodium amide $(684 \mathrm{mg}, 17.5 \mathrm{mmol})$ at room temperature. After stirring at reflux for $45 \mathrm{~h}$, the reaction was quenched with $\mathrm{H}_{2} \mathrm{O}$, and the mixture was extracted with EtOAc three times. The combined organic extracts were washed with $\mathrm{H}_{2} \mathrm{O}$ and brine, dried over anhydrous sodium sulfate, and filtered. The organic solvents were removed under reduced pressure to give a crude material, which was purified by silica gel column chromatography (EtOAc) to afford bis-acetal 27 (1.21 g, 3.90 mmol, 89\%). A colorless oil; IR (film): 2937, 2832, 1474, 1414, 1278, 1177, 1167, 1138, 1071, 1053, 1036, $852 \mathrm{~cm}^{-1} ;{ }^{1} \mathrm{H}$ NMR (400 MHz, $\left.\mathrm{CDCl}_{3}\right): \delta 3.96$ (s, 6H), 3.42 (s, $12 \mathrm{H}), 3.22(\mathrm{~s}, 4 \mathrm{H}) ;{ }^{13} \mathrm{C} \mathrm{NMR}\left(100 \mathrm{MHz}, \mathrm{CDCl}_{3}\right): \delta 144.7,135.7,129.4,105.6,60.2,52.0,39.0$; HRMS (ESI) $m / z$ : calcd. for $\mathrm{C}_{16} \mathrm{H}_{22} \mathrm{NaO}_{6} 333.1309\left[\mathrm{M}+\mathrm{Na}^{+}\right]$found 333.1293. 


\section{Sulfonate 29}
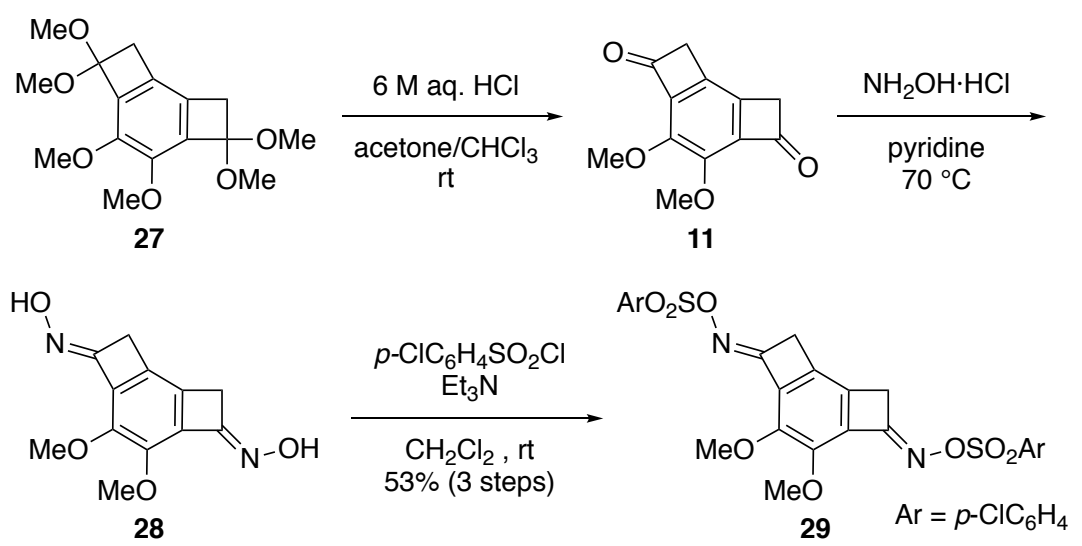

To a solution of bis-acetal $27(115 \mathrm{mg}, 370 \mu \mathrm{mol})$ in acetone $(1.1 \mathrm{~mL})$ and $\mathrm{CHCl}_{3}(1.1 \mathrm{~mL})$ was added $6 \mathrm{M}$ aqueous $\mathrm{HCl}(0.37 \mathrm{~mL})$ at room temperature. After stirring at room temperature for $2 \mathrm{~h}$, acetone $(1.1 \mathrm{~mL})$ and $6 \mathrm{M}$ aqueous $\mathrm{HCl}(0.37 \mathrm{~mL})$ were added, and the mixture was stirred at room temperature for $10.5 \mathrm{~h}$. All organic solvents were removed under reduced pressure, and the mixture was extracted with EtOAc three times. The combined organic extracts were washed with $\mathrm{H}_{2} \mathrm{O}$ and brine, dried over anhydrous sodium sulfate, and filtered. The organic solvents were removed under reduced pressure to give a crude 11, which was used to the next reaction without further purification. To a solution of the crude $\mathbf{1 1}$ in pyridine $(3.7 \mathrm{~mL})$ was added hydroxylamine hydrochloride $\left(257 \mathrm{mg}, 3.70 \mathrm{mmol}\right.$ ) at room temperature. After stirring at $70{ }^{\circ} \mathrm{C}$ for $22 \mathrm{~h}$, pyridine was removed under reduced pressure. To the residue was added $\mathrm{H}_{2} \mathrm{O}$, and the mixture was extracted with EtOAc six times. The combined organic extracts were dried over anhydrous sodium sulfate, and filtered. The organic solvents were removed under reduced pressure to give a crude $\mathbf{2 8}$, which was used to the next reaction without further purification. To a solution of the crude 28 and $\mathrm{Et}_{3} \mathrm{~N}$ (155 $\mu \mathrm{L}, 1.11 \mathrm{mmol})$ in $\mathrm{CH}_{2} \mathrm{Cl}_{2}(3.7 \mathrm{~mL})$ was added $p-\mathrm{ClC}_{6} \mathrm{H}_{4} \mathrm{SO}_{2} \mathrm{Cl}(196 \mathrm{mg}, 929 \mathrm{mmol})$ at room temperature. After stirring at room temperature for $3.5 \mathrm{~h}$, precipitates were collected by filtration and purified by trituration $\left(\mathrm{CH}_{2} \mathrm{Cl}_{2}\right)$ to afford sulfonate 29 (118 mg, $197 \mu \mathrm{mol}, 53 \%, 3$ steps). A colorless solid; mp 197-198 ${ }^{\circ} \mathrm{C}$, decomposition, (hexanes-THF, colorless prisms); IR (film): 1494 , 1385, 1292, 1240, 1190, 1095, 1084, 1015, 840, 812, 791, 754, 666, 616, 556, $544 \mathrm{~cm}^{-1} ;{ }^{1} \mathrm{H} \mathrm{NMR}$ (400 MHz, DMSO- $\left.d_{6}\right): \delta 7.90(\mathrm{~d}, 4 \mathrm{H}, J=8.8 \mathrm{~Hz}), 7.53(\mathrm{~d}, 4 \mathrm{H}, J=8.8 \mathrm{~Hz}), 4.06(\mathrm{~s}, 6 \mathrm{H}), 3.83(\mathrm{~s}$, $4 \mathrm{H}) ;{ }^{13} \mathrm{C}$ NMR (100 MHz, DMSO- $\left.d_{6}\right): \delta 160.3,144.2,140.0,133.1,130.5,129.8,128.6,127.2$, 59.3, 38.0; HRMS (ESI) $m / z$ : calcd. for $\mathrm{C}_{24} \mathrm{H}_{19} \mathrm{Cl}_{2} \mathrm{~N}_{2} \mathrm{O}_{8} \mathrm{~S}_{2} 596.9954\left[\mathrm{M}+\mathrm{H}^{+}\right]$found 596.9937 .

\section{Indole 30}
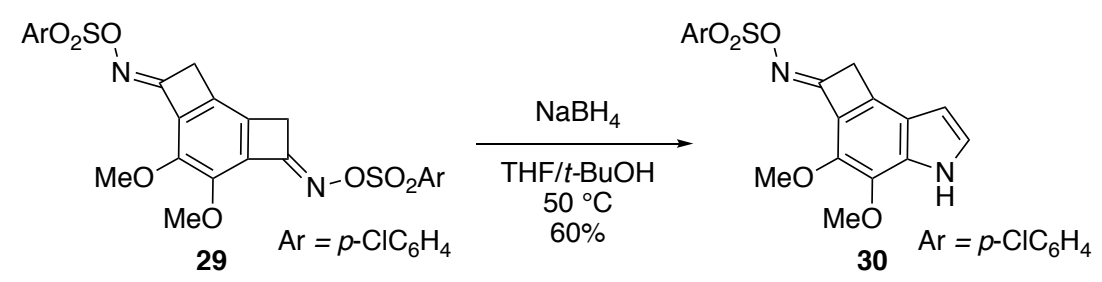

To a solution of sulfonate $29(500 \mathrm{mg}, 837 \mu \mathrm{mol})$ in THF $(15 \mathrm{~mL})$ and $t$-BuOH $(1.5 \mathrm{~mL})$ was added $\mathrm{NaBH}_{4}(95.0 \mathrm{mg}, 2.51 \mathrm{mmol})$ at room temperature. After stirring at $50{ }^{\circ} \mathrm{C}$ for $7 \mathrm{~h}$, the 
reaction was quenched with $\mathrm{H}_{2} \mathrm{O}$, and the mixture was extracted with EtOAc three times. The combined organic extracts were washed with $\mathrm{H}_{2} \mathrm{O}$ and brine, dried over anhydrous sodium sulfate, and filtered. The organic solvents were removed under reduced pressure to give a crude material, which was purified by flash silica gel column chromatography (toluene-EtOAc $=5: 1$ ) to afford indole 30 (206 mg, $506 \mu \mathrm{mol}, 60 \%$ ). A colorless amorphous; IR (film): 3398, 2360, 1606, 1498, 1397, 1370, 1332, 1260, 1189, 1164, 839, 819, 754, 670, 616, 551, $545 \mathrm{~cm}^{-1}$; ${ }^{1} \mathrm{H}$ NMR (400 MHz, $\left.\mathrm{CDCl}_{3}\right): \delta 8.51(\mathrm{br} \mathrm{s}, 1 \mathrm{H}), 7.95(\mathrm{~d}, 2 \mathrm{H}, J=8.8 \mathrm{~Hz}), 7.52(\mathrm{~d}, 2 \mathrm{H}, J=8.8 \mathrm{~Hz}), 7.18(\mathrm{~s}, 1 \mathrm{H}), 6.41(\mathrm{~s}$, $1 \mathrm{H}), 4.05(\mathrm{~s}, 3 \mathrm{H}), 3.97(\mathrm{~s}, 2 \mathrm{H}), 3.94(\mathrm{~s}, 3 \mathrm{H}) ;{ }^{13} \mathrm{C}$ NMR (100 MHz, DMSO- $\left.d_{6}\right): \delta 160.7,140.3$, 139.6, 135.7, 135.3, 133.7, 131.9, 130.4, 129.7, 127.7, 119.6, 116.1, 100.3, 60.8, 59.1, 37.8; HRMS (ESI) $m / z$ : calcd. for $\mathrm{C}_{18} \mathrm{H}_{16} \mathrm{ClN}_{2} \mathrm{O}_{5} \mathrm{~S} 407.0463\left[\mathrm{M}+\mathrm{H}^{+}\right]$found 407.0452 .

\section{Pyrroloindole 9}

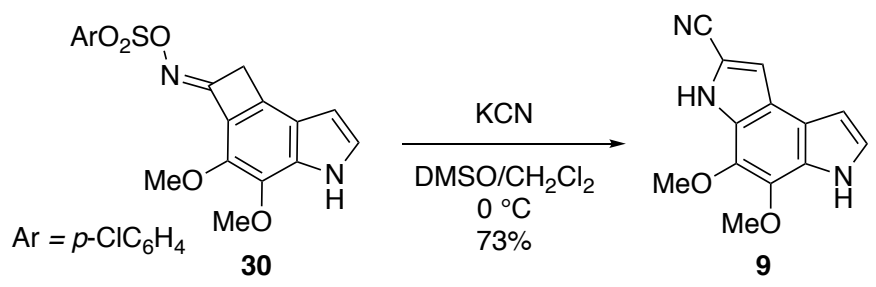

To a solution of sulfonate $30(517 \mathrm{mg}, 1.27 \mathrm{mmol})$ in DMSO $(9.5 \mathrm{~mL})$ and $\mathrm{CH}_{2} \mathrm{Cl}_{2}(3.2 \mathrm{~mL})$ was added potassium cyanide $(827 \mathrm{mg}, 12.7 \mathrm{mmol})$ at $0{ }^{\circ} \mathrm{C}$. After stirring at $0{ }^{\circ} \mathrm{C}$ for $29 \mathrm{~h}$, the reaction was quenched with $\mathrm{H}_{2} \mathrm{O}$, and the mixture was extracted with $\mathrm{Et}_{2} \mathrm{O}$ three times. The combined organic extracts were washed with $\mathrm{H}_{2} \mathrm{O}$ and brine, dried over anhydrous sodium sulfate, and filtered. The organic solvents were removed under reduced pressure to give a crude material, which was purified by flash silica gel column chromatography (hexanes-EtOAc $=1: 1$ ) to afford pyrroloindole 9 (225 mg, $932 \mu \mathrm{mol}, 73 \%)$. A colorless solid; mp 186-187 ${ }^{\circ} \mathrm{C}$ (hexanes-EtOAc, colorless prisms); IR (film): 3325, 2220, 1521, 1370, 1353, 1288, 1252, 1150, 1130, 1074, 1053, 956, 772, $733 \mathrm{~cm}^{-1} ;{ }^{1} \mathrm{H}$ NMR $\left(400 \mathrm{MHz}, \mathrm{CDCl}_{3}\right): \delta 8.87$ (br s, $\left.1 \mathrm{H}\right), 8.53$ (br s, $\left.1 \mathrm{H}\right), 7.34(\mathrm{~d}, 1 \mathrm{H}, J=$ $2.4 \mathrm{~Hz}), 7.22(\mathrm{dd}, 1 \mathrm{H}, J=2.4,2.4 \mathrm{~Hz}), 6.73(\mathrm{dd}, 1 \mathrm{H}, J=2.4,2.4 \mathrm{~Hz}), 4.11(\mathrm{~s}, 3 \mathrm{H}), 4.04(\mathrm{~s}, 3 \mathrm{H}) ;{ }^{13} \mathrm{C}$ NMR $\left(100 \mathrm{MHz}, \mathrm{CDCl}_{3}\right): \delta 137.8,133.1,128.3,125.7,122.7,116.5,115.6,115.0,113.2,103.4$, 102.0, 61.4, 61.2; HRMS (ESI) $m / z$ : calcd. for $\mathrm{C}_{13} \mathrm{H}_{12} \mathrm{~N}_{3} \mathrm{O}_{2} 242.0924\left[\mathrm{M}+\mathrm{H}^{+}\right]$found 242.0917 .

\section{Aldehyde 31}
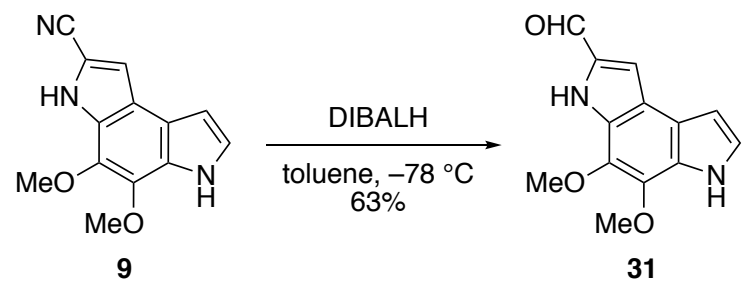

To a solution of nitrile $9(100 \mathrm{mg}, 415 \mu \mathrm{mol})$ in toluene $(1.3 \mathrm{~mL})$ was added DIBALH $(1.00$ $\mathrm{M}$ in toluene, $1.25 \mathrm{~mL}, 1.25 \mathrm{mmol}$ ) at $-78{ }^{\circ} \mathrm{C}$. After stirring at $-78{ }^{\circ} \mathrm{C}$ for $2.5 \mathrm{~h}$, the reaction was quenched with saturated aqueous Rochelle salt, and the mixture was stirred for $20 \mathrm{~h}$. The mixture was extracted with EtOAc three times. The combined organic extracts were washed with saturated aqueous Rochelle salt, $\mathrm{H}_{2} \mathrm{O}$ and brine, dried over anhydrous sodium sulfate, and filtered. The 
organic solvents were removed under reduced pressure to give a crude material, which was purified by flash silica gel column chromatography (toluene-EtOAc $=5: 1)$ to afford aldehyde $31(63.4 \mathrm{mg}$, $260 \mu \mathrm{mol}, 63 \%$ ). A yellow oil; IR (film): 3308, 2360, 2340, 1652, 1615, 1519, 1288, 1130, 1098, 1074, $1055 \mathrm{~cm}^{-1} ;{ }_{1}^{1} \mathrm{H}$ NMR (400 MHz, $\mathrm{CDCl}_{3}$ ): $\delta 9.74$ (s, 1H), 9.22 (br s, $1 \mathrm{H}$ ), 8.57 (br s, $\left.1 \mathrm{H}\right), 7.43$ $(\mathrm{d}, 1 \mathrm{H}, J=2.0 \mathrm{~Hz}), 7.22(\mathrm{dd}, 1 \mathrm{H}, J=2.8,2.8 \mathrm{~Hz}), 6.77(\mathrm{dd}, 1 \mathrm{H}, J=2.8,2.8 \mathrm{~Hz}), 4.14(\mathrm{~s}, 3 \mathrm{H}), 4.01$ $(\mathrm{s}, 3 \mathrm{H}) ;{ }^{13} \mathrm{C} \mathrm{NMR}\left(100 \mathrm{MHz}, \mathrm{CDCl}_{3}\right): \delta 180.4,139.1,134.5,133.1,130.4,125.4,122.6,117.5$, 117.1, 113.9, 102.2, 61.4, 61.1; HRMS (ESI) $m / z$ : calcd. for $\mathrm{C}_{13} \mathrm{H}_{13} \mathrm{~N}_{2} \mathrm{O}_{3} 245.0921\left[\mathrm{M}+\mathrm{H}^{+}\right]$found 245.0924 .

\section{Methyl ester 33}
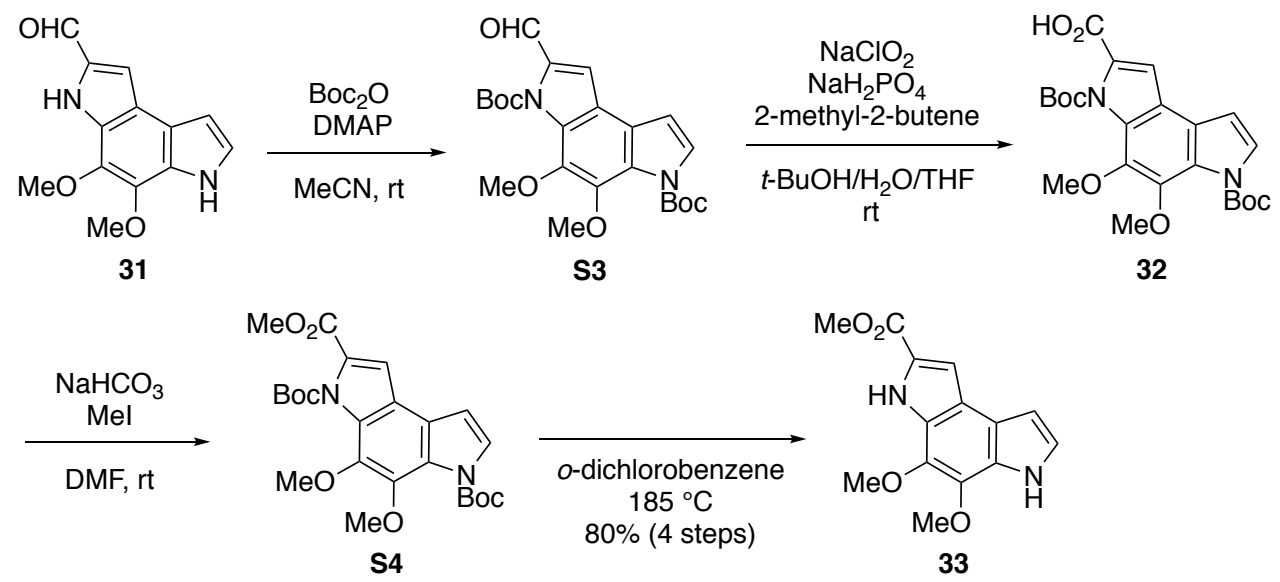

To a solution of aldehyde $31(250 \mathrm{mg}, 1.02 \mathrm{mmol})$ and DMAP $(12.5 \mathrm{mg}, 0.102 \mathrm{mmol})$ in $\mathrm{MeCN}(10 \mathrm{~mL})$ was added $\mathrm{Boc}_{2} \mathrm{O}(1.12 \mathrm{~g}, 5.11 \mathrm{mmol})$ at room temperature. After stirring at room temperature for $1 \mathrm{~h}, \mathrm{MeCN}$ was removed under reduced pressure. The residue was purified by passing through a silica gel short column chromatography (toluene-EtOAc $=3: 1$ ) to afford Boc carbamate $\mathbf{S 3}$ as a mixture containing an unidentified byproduct, which was used to the next reaction without further purification. To a solution of the crude $\mathbf{S 3}$ in $t$ - $\mathrm{BuOH}(2.0 \mathrm{~mL}), \mathrm{H}_{2} \mathrm{O}(8.0$ $\mathrm{mL})$, and THF $(8.0 \mathrm{~mL})$ were added $\mathrm{NaH}_{2} \mathrm{PO}_{4}(957 \mathrm{mg}, 6.13 \mathrm{mmol})$, 2-methyl-2-butene $(2.17 \mathrm{ml}$, $20.4 \mathrm{mmol})$, and $\mathrm{NaClO}_{2}(277 \mathrm{mg}, 3.07 \mu \mathrm{mol})$ at room temperature. After stirring at room temperature for $12 \mathrm{~h}$, the mixture was diluted by $\mathrm{H}_{2} \mathrm{O}$, and the mixture was extracted with EtOAc three times. The combined organic extracts were dried over anhydrous sodium sulfate, and filtered. The organic solvents were removed under reduced pressure to give a crude $\mathbf{3 2}$, which was used to the next reaction without further purification. To a solution of the crude $\mathbf{3 2}$ and $\mathrm{NaHCO}_{3}(171 \mathrm{mg}$, $2.04 \mathrm{mmol})$ in DMF $(10.0 \mathrm{ml})$ was added MeI $(127 \mu \mathrm{L}, 2.04 \mathrm{mmol})$ at room temperature. After stirring at room temperature for $2.5 \mathrm{~h}$, the reaction was quenched with $\mathrm{H}_{2} \mathrm{O}$, and the mixture was extracted with $\mathrm{Et}_{2} \mathrm{O}$ five times. The combined organic extracts were dried over anhydrous sodium sulfate, and filtered. The organic solvents were removed under reduced pressure to give a crude $\mathbf{S 4}$, which was used to the next reaction without further purification. A solution of the crude $\mathbf{S 4}$ in $o$-dichlorobenzene $(10 \mathrm{ml})$ was stirred at $185{ }^{\circ} \mathrm{C}$ for $7.5 \mathrm{~h}$, and the mixture was directly applied to silica gel short column chromatography (100\% hexanes to $100 \%$ EtOAc) to give a crude material. The crude material was purified by flash silica gel column chromatography (toluene-EtOAc $=7: 1$ ) 
to afford methyl ester 33 (224 mg, $818 \mu \mathrm{mol}, 80 \%$, 4 steps). A yellow solid; mp $189-190{ }^{\circ} \mathrm{C}$ (hexanes-EtOAc, colorless prisms); IR (film): 3335, 2939, 1693, 1518, 1443, 1379, 1288, 1265, 1202, 1169, 1148, $1053 \mathrm{~cm}^{-1} ;{ }^{1} \mathrm{H}$ NMR (400 MHz, $\mathrm{CDCl}_{3}$ ): $\delta 9.15$ (br s, 1H), 8.56 (br s, 1H), 7.41 (br s, 1H), 7.17 (br s, 1H), 6.73 (br s, 1H), 4.08 (s, 3H), 4.01 (s, 3H), 3.93 (s, 3H); ${ }^{13} \mathrm{C}$ NMR (100 $\mathrm{MHz}_{\mathrm{CDCl}}$ ): $\delta 162.4,137.4,133.5,128.3,125.4,124.9,122.3,117.2,116.9,108.0,101.9,61.3$, 61.1, 51.7; HRMS (ESI) $m / z$ : calcd. for $\mathrm{C}_{14} \mathrm{H}_{15} \mathrm{~N}_{2} \mathrm{O}_{4} 275.1026\left[\mathrm{M}+\mathrm{H}^{+}\right]$found 275.1014. Spectroscopic data were identical with those previously reporetd. ${ }^{5}$

\section{Benzyl ester 34}
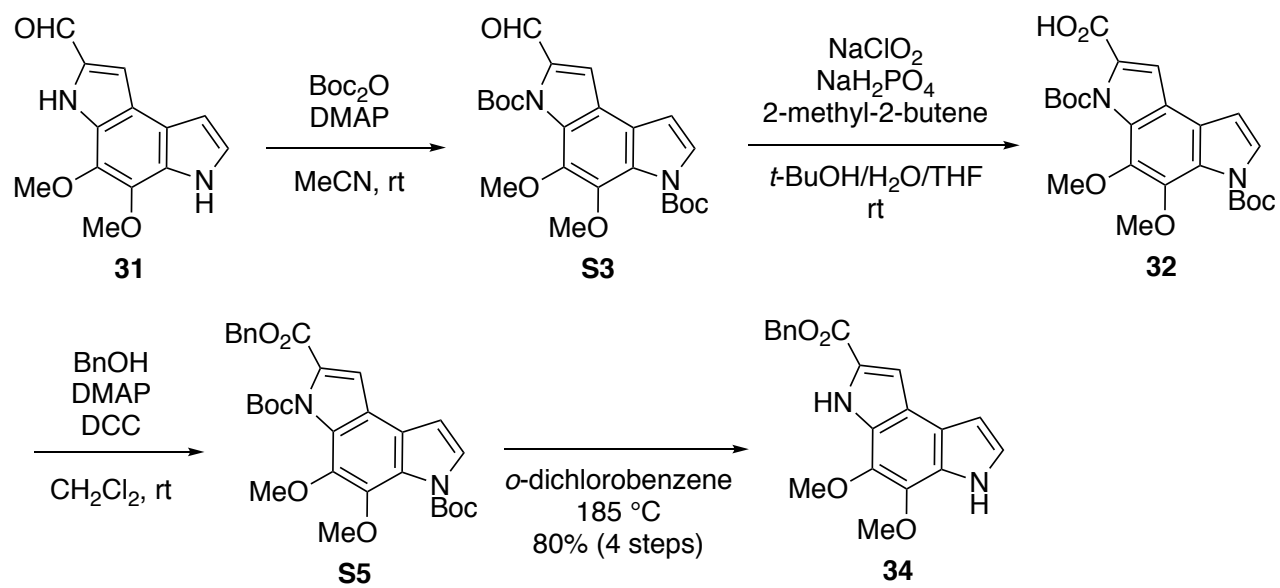

To a solution of aldehyde $31(159 \mathrm{mg}, 0.651 \mathrm{mmol})$ and DMAP $(8.0 \mathrm{mg}, 65.2 \mu \mathrm{mol})$ in $\mathrm{MeCN}(6.5 \mathrm{~mL})$ was added $\mathrm{Boc}_{2} \mathrm{O}(711 \mathrm{mg}, 3.26 \mathrm{mmol})$ at room temperature. After stirring at room temperature for $50 \mathrm{~min}, \mathrm{MeCN}$ was removed under reduced pressure. The residue was purified by passing through a silica gel short column chromatography (toluene-EtOAc $=3: 1$ ) to afford Boc carbamate $\mathbf{S 3}$ as a mixture containing an unidentified byproduct, which was used to the next reaction without further purification. To a solution of the crude $\mathbf{S 3}$ in $t$ - $\mathrm{BuOH}(1.3 \mathrm{~mL}), \mathrm{H}_{2} \mathrm{O}(5.2$ $\mathrm{mL})$, and THF $(5.2 \mathrm{~mL})$ were added $\mathrm{NaH}_{2} \mathrm{PO}_{4}(610 \mathrm{mg}, 3.91 \mathrm{mmol})$, 2-methyl-2-butene $(1.39 \mathrm{ml}$, $13.0 \mathrm{mmol})$, and $\mathrm{NaClO}_{2}(177 \mathrm{mg}, 1.96 \mathrm{mmol})$ at room temperature. After stirring at room temperature for $20 \mathrm{~h}$, the reaction was diluted by $\mathrm{H}_{2} \mathrm{O}$, and the mixture was extracted with EtOAc three times. The combined organic extracts were dried over anhydrous sodium sulfate, and filtered. The organic solvents were removed under reduced pressure to give a crude 32, which was used to the next reaction without further purification. To a solution of the crude 32 in $\mathrm{CH}_{2} \mathrm{Cl}_{2}$ (4.2 ml) were added $\mathrm{BnOH}(80.0 \mu \mathrm{L}, 0.781 \mathrm{mmol})$, DCC (136 mg, $0.658 \mathrm{mmol})$, and DMAP (15.9 mg, 0.130 $\mathrm{mmol}$ ) at room temperature. After stirring at room temperature for $8 \mathrm{~h}$, the mixture was filtered through a pad of Celite ${ }^{\circledR}\left(\mathrm{CH}_{2} \mathrm{Cl}_{2}\right)$, and the filtrate was concentrated under reduced pressure. The residue was diluted by EtOAc and washed with brine. The combined organic solvents were dried over anhydrous sodium sulfate, and filtered. The organic solvents were removed under reduced pressure to give a crude S5, which was purified by flash silica gel column chromatography (hexanes-EtOAc $=6: 1$ ) to afford $\mathbf{S 5}$ as a mixture containing unidentified byproduct. A solution of the crude $\mathbf{S 5}$ in $o$-dichlorobenzene $(6.5 \mathrm{ml})$ was stirred at $185{ }^{\circ} \mathrm{C}$ for $8.5 \mathrm{~h}$, and the mixture was directly applied to silica gel short column chromatography (100\% hexane to $100 \%$ EtOAc) to give a 
crude material. The crude material was purified by flash silica gel column chromatography (hexanes-EtOAc = 2:1) to afford benzyl ester $34(183 \mathrm{mg}, 0.522 \mathrm{mmol}, 80 \%$, 4 steps). A colorless amorphous; IR (film): 3431, 3338, 3032, 3006, 2937, 1690, 1518, 1454, 1389, 1351, 1287, 1262, 1195, 1168, 1074, 1053, 758, 697, $569 \mathrm{~cm}^{-1} ;{ }^{1} \mathrm{H}$ NMR (400 MHz, $\left.\mathrm{CDCl}_{3}\right): \delta 9.06$ (br s, $\left.1 \mathrm{H}\right), 8.47$ (br s, 1H), 7.49-7.35 (m, 6H), $7.18(\mathrm{dd}, 1 \mathrm{H}, J=2.4,2.4 \mathrm{~Hz}), 6.72(\mathrm{dd}, 1 \mathrm{H}, J=2.4,2.4 \mathrm{~Hz}), 5.40$ (s, 2H), 4.09 (s, 3H), $4.02(\mathrm{~s}, 3 \mathrm{H}) ;{ }^{13} \mathrm{C} \mathrm{NMR}\left(100 \mathrm{MHz}, \mathrm{CDCl}_{3}\right): \delta 161.8,137.5,136.1,133.5,128.6$, $128.4,128.3,128.2$, 125.5, 124.8, 122.2, 117.2, 116.9, 108.4, 102.0, 66.3, 61.4, 61.1; HRMS (ESI) $\mathrm{m} / \mathrm{z}$ : calcd. for $\mathrm{C}_{20} \mathrm{H}_{19} \mathrm{~N}_{2} \mathrm{O}_{4} 351.1339\left[\mathrm{M}+\mathrm{H}^{+}\right]$found 351.1351 .

\section{Carbamate 36}
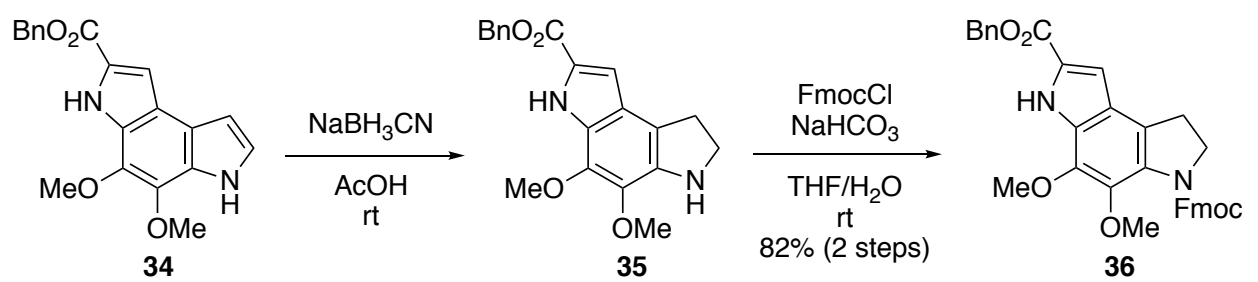

To a solution of $34(105 \mathrm{mg}, 300 \mu \mathrm{mol})$ in $\mathrm{AcOH}(0.8 \mathrm{~mL})$ was added $\mathrm{NaBH}_{3} \mathrm{CN}(94.3 \mathrm{mg}$, $1.50 \mathrm{mmol}$ ) at room temperature. After stirring at room temperature for $10 \mathrm{~h}$, the reaction was quenched with saturated aqueous $\mathrm{NaHCO}_{3}$, and the mixture was extracted with $\mathrm{CH}_{2} \mathrm{Cl}_{2}$ three times. The combined organic extracts were washed with saturated aqueous $\mathrm{NaHCO}_{3}$ and brine, dried over anhydrous sodium sulfate, and filtered. The organic solvents were removed under reduced pressure to give a crude 35, which was used to the next reaction without further purification. To a solution of the crude 35 and $\mathrm{NaHCO}_{3}(75.6 \mathrm{mg}, 900 \mu \mathrm{mol})$ in THF $(1.5 \mathrm{~mL})$ and $\mathrm{H}_{2} \mathrm{O}(0.5 \mathrm{~mL})$ was added FmocCl $(85.4 \mathrm{mg}, 330 \mu \mathrm{mol})$ at room temperature. After stirring at room temperature for $20 \mathrm{~min}$, the mixture was extracted with EtOAc three times. The combined organic extracts were washed with brine, dried over anhydrous sodium sulfate, and filtered. The organic solvents were removed under reduced pressure to give a crude material, which was purified by flash silica gel column chromatography (hexanes-EtOAc $=3: 1)$ to afford $36(142 \mathrm{mg}, 406 \mu \mathrm{mol}, 82 \%, 2$ steps). A yellow amorphous; IR (film): 3447, 3314, 2944, 2897, 2848, 1707, 1532, 1506, 1450, 1415, 1326, 1286, 1253, 1209, 1191, 1156, 757, 739, $698 \mathrm{~cm}^{-1} ;{ }^{1} \mathrm{H}$ NMR (400 MHz, $\mathrm{CDCl}_{3}$ ): $\delta 8.97$ (br s, 1H), 7.74 $(\mathrm{d}, 2 \mathrm{H}, J=8.0 \mathrm{~Hz}), 7.57(\mathrm{~d}, 2 \mathrm{H}, J=7.6 \mathrm{~Hz}), 7.47-7.36(\mathrm{~m}, 7 \mathrm{H}), 7.27(\mathrm{dd}, 2 \mathrm{H}, J=7.2,7.2 \mathrm{~Hz})$, $7.10(\mathrm{~d}, 1 \mathrm{H}, J=2.0 \mathrm{~Hz}), 5.39(\mathrm{~s}, 2 \mathrm{H}), 4.56(\mathrm{~d}, 2 \mathrm{H}, J=6.8 \mathrm{~Hz}), 4.31(\mathrm{t}, 1 \mathrm{H}, J=6.8 \mathrm{~Hz}), 4.17(\mathrm{t}, 2 \mathrm{H}$, $J=8.0 \mathrm{~Hz}), 3.99(\mathrm{~s}, 3 \mathrm{H}), 3.88(\mathrm{~s}, 3 \mathrm{H}), 3.08(\mathrm{t}, 2 \mathrm{H}, J=8.0 \mathrm{~Hz}) ;{ }^{13} \mathrm{C} \mathrm{NMR}\left(100 \mathrm{MHz}, \mathrm{CDCl}_{3}\right): \delta$ 161.4, 155.1, 144.0, 142.2, 141.3, 137.6, 135.7, 130.9, 130.1, 128.7, 128.43, 128.36, 127.66, 127.63, 127.0, 125.1, 121.8, 120.5, 119.9, 107.4, 67.6, 66.7, 61.1, 60.3, 51.8, 47.4, 28.6; HRMS (ESI) $m / z$ : calcd. for $\mathrm{C}_{35} \mathrm{H}_{31} \mathrm{~N}_{2} \mathrm{O}_{6} 575.2177\left[\mathrm{M}+\mathrm{H}^{+}\right]$found 575.2160 . 


\section{Phenol 37}
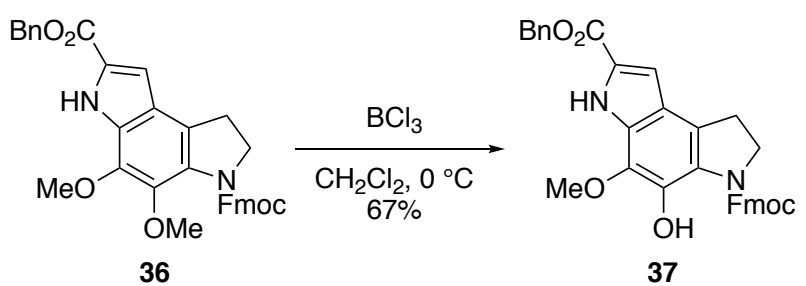

To a solution of $36(142 \mathrm{mg}, 247 \mu \mathrm{mol})$ in $\mathrm{CH}_{2} \mathrm{Cl}_{2}(4.7 \mathrm{~mL})$ was added $\mathrm{BCl}_{3}(1.0 \mathrm{M}$ in $\left.\mathrm{CH}_{2} \mathrm{Cl}_{2}, 247 \mu \mathrm{L}, 247 \mu \mathrm{mol}\right)$ at $0{ }^{\circ} \mathrm{C}$. After stirring at $0{ }^{\circ} \mathrm{C}$ for $20 \mathrm{~min}$, additional amount of $\mathrm{BCl}_{3}$ (1.0 $\mathrm{M}$ in $\mathrm{CH}_{2} \mathrm{Cl}_{2}, 130 \mu \mathrm{L}, 130 \mu \mathrm{mol}$ ) was added to the reaction mixture at $0{ }^{\circ} \mathrm{C}$, and the mixture was stirred for $20 \mathrm{~min}$. The reaction was quenched with saturated aqueous $\mathrm{NH}_{4} \mathrm{Cl}$, and the mixture was extracted with $\mathrm{CH}_{2} \mathrm{Cl}_{2}$ four times. The combined organic extracts were washed with brine, dried over anhydrous sodium sulfate, and filtered. The organic solvents were removed under reduced pressure to give a crude material, which was purified by flash silica gel column chromatography (hexanes-EtOAc-acetone $=4: 1: 1)$ to afford phenol $37(92.5 \mathrm{mg}, 165 \mu \mathrm{mol}, 67 \%)$. A colorless amorphous; IR (film): 3453, 3319, 3065, 3016, 2937, 2835, 1696, 1663, 1469, 1452, 1337, 1289, 1255, 1152, 750, 697, $541 \mathrm{~cm}^{-1} ;{ }^{1} \mathrm{H}$ NMR (400 MHz, $\left.\mathrm{CDCl}_{3}\right): \delta 11.21(\mathrm{~s}, 1 \mathrm{H}), 8.82(\mathrm{br}$ s, 1H), $7.79(\mathrm{~d}, 2 \mathrm{H}, J=7.2 \mathrm{~Hz}), 7.62(\mathrm{~d}, 2 \mathrm{H}, J=8.0 \mathrm{~Hz}), 7.45-7.34(\mathrm{~m}, 9 \mathrm{H}), 7.06(\mathrm{~d}, 1 \mathrm{H}, J=2.0$ $\mathrm{Hz}), 5.37(\mathrm{~s}, 2 \mathrm{H}), 4.60(\mathrm{~d}, 2 \mathrm{H}, J=7.2 \mathrm{~Hz}), 4.33(\mathrm{t}, 1 \mathrm{H}, J=7.2 \mathrm{~Hz}), 4.09(\mathrm{t}, 2 \mathrm{H}, J=8.8 \mathrm{~Hz}), 4.01(\mathrm{~s}$, $3 \mathrm{H}), 3.19(\mathrm{t}, 2 \mathrm{H}, J=8.6 \mathrm{~Hz}) ;{ }^{13} \mathrm{C} \mathrm{NMR}\left(100 \mathrm{MHz}, \mathrm{CDCl}_{3}\right): \delta 161.3,155.1,143.4,141.3,138.1$, $135.8,132.77,132.76,130.6,128.6,128.3,127.8,127.1,126.7,125.7,124.8,120.0,119.4,117.6$, 107.4, 68.7, 66.5, 60.6, 49.2, 47.0, 26.6; HRMS (ESI) $\mathrm{m} / z$ : calcd. for $\mathrm{C}_{34} \mathrm{H}_{29} \mathrm{~N}_{2} \mathrm{O}_{6} 561.2020$ $\left[\mathrm{M}+\mathrm{H}^{+}\right]$found 561.2001 .

\section{Middle segment 38}

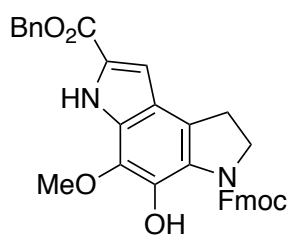

37

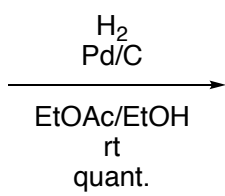

quant.

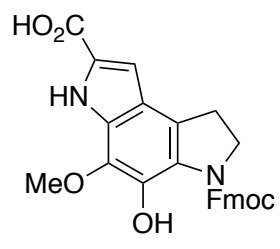

38

A solution of $37(92.5 \mathrm{mg}, 165 \mu \mathrm{mol})$ and $10 \%$ palladium on activated carbon (17.6 $\mathrm{mg}, 16.5$ $\mu \mathrm{mol})$ in a mixture of EtOAc $(0.8 \mathrm{~mL})$ and $\mathrm{EtOH}(0.8 \mathrm{~mL})$ was stirred under a hydrogen atmosphere $(1 \mathrm{~atm})$ at room temperature for $17 \mathrm{~h}$. The reaction mixture was filtered through a pad of Celite ${ }^{\circledR}$ and the filtrate was concentrated under reduced pressure to give the middle segment 38 (77.6 mg, quant). A colorless amorphous; IR (film): 2938, 2907, 2834, 1660, 1468, 1446, 1337, 1291, 1266, 1159, 1138, $739 \mathrm{~cm}^{-1} ;{ }^{1} \mathrm{H}$ NMR (400 MHz, $\left.\mathrm{CDCl}_{3}\right): \delta 11,3(\mathrm{~s}, 1 \mathrm{H}), 8.86(\mathrm{~s}, 1 \mathrm{H}), 7.80$ $(\mathrm{d}, 2 \mathrm{H}, J=7.2 \mathrm{~Hz}), 7.62(\mathrm{~d}, 2 \mathrm{H}, J=7.6 \mathrm{~Hz}), 7.43(\mathrm{dd}, 2 \mathrm{H}, J=7.2,7.6 \mathrm{~Hz}), 7.35(\mathrm{dd}, 2 \mathrm{H}, J=7.2$, $7.6 \mathrm{~Hz}), 7.13(\mathrm{~d}, 1 \mathrm{H}, J=2.0 \mathrm{~Hz}), 4.60(\mathrm{~d}, 2 \mathrm{H}, J=6.8 \mathrm{~Hz}), 4.33(\mathrm{t}, 1 \mathrm{H}, J=6.8 \mathrm{~Hz}), 4.11(\mathrm{t}, 2 \mathrm{H}, J=$ $8.8 \mathrm{~Hz}), 4.03(\mathrm{~s}, 3 \mathrm{H}), 3.22(\mathrm{t}, 2 \mathrm{H}, J=8.8 \mathrm{~Hz}) ;{ }^{13} \mathrm{C} \mathrm{NMR}\left(100 \mathrm{MHz}, \mathrm{CDCl}_{3}\right): \delta 165.3,155.3,143.5$, 141.4, 138.6, 132.8, 131.1, 128.0, 127.2, 126.1, 125.8, 124.9, 120.2, 119.7, 117.7, 109.0, 68.9, 60.8, 49.4, 47.1, 26.8; HRMS (ESI $\left.{ }^{-}\right) \mathrm{m} / z$ : calcd. for $\mathrm{C}_{27} \mathrm{H}_{21} \mathrm{~N}_{2} \mathrm{O}_{6} 469.1405\left[\mathrm{M}-\mathrm{H}^{+}\right]$found 469.1385 . 


\section{Carbamate 40}

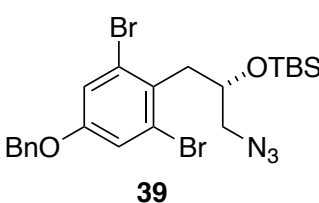

39

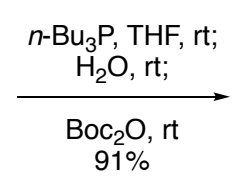

$91 \%$

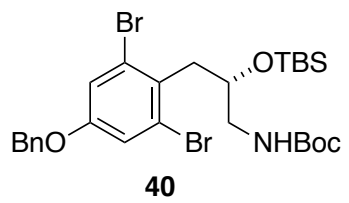

40

To a solution of $39^{6}(22.7 \mathrm{~g}, 46.3 \mathrm{mmol})$ in THF $(116 \mathrm{~mL})$ was added tri- $n$-butylphosphine (12.9 mL, $51.6 \mathrm{mmol})$ at room temperature. After stirring at room temperature for $20 \mathrm{~min}, \mathrm{H}_{2} \mathrm{O}(46$ $\mathrm{mL}$ ) was added to the mixture, and the resulting solution was stirred for $30 \mathrm{~min}$ at room temperature. To the pale-yellow solution was added $\mathrm{Boc}_{2} \mathrm{O}(11.8 \mathrm{~g}, 54.1 \mathrm{mmol})$ at room temperature. After stirring at room temperature for $20 \mathrm{~min}$, to the mixture was added $\mathrm{H}_{2} \mathrm{O}$, and the mixture was extracted with EtOAc three times. The combined organic extracts were washed with brine, dried over anhydrous sodium sulfate, and filtered. The organic solvents were removed under reduced pressure to give a crude material, which was purified by silica gel column chromatography (hexanes-EtOAc $=6: 1)$ to afford $N$-Boc carbamate 40 (26.5 g, $42.0 \mathrm{mmol}, 91 \%)$. A colorless oil; $[\alpha]_{\mathrm{D}}{ }^{27}-16.5$ (c 0.81, $\mathrm{CHCl}_{3}$ ); IR (film): 2953, 2929, 1715, 1594, 1543, 1499, 1470, 1453, 1365, 1253, 1171, 1107, 836, $776 \mathrm{~cm}^{-1} ;{ }^{1} \mathrm{H}$ NMR (400 MHz, $\left.\mathrm{CDCl}_{3}\right): \delta 7.40-7.33(\mathrm{~m}, 5 \mathrm{H}), 7.17(\mathrm{~s}, 2 \mathrm{H})$, $5.00(\mathrm{~s}, 2 \mathrm{H}), 4.82(\mathrm{br}, 1 \mathrm{H}), 4.25-4.21(\mathrm{~m}, 1 \mathrm{H}), 3.23-3.17(\mathrm{~m}, 3 \mathrm{H}), 3.02(\mathrm{dd}, 1 \mathrm{H}, J=13.6,6.0 \mathrm{~Hz})$, $1.44(\mathrm{~s}, 9 \mathrm{H}), 0.84(\mathrm{~s}, 9 \mathrm{H}),-0.02(\mathrm{~s}, 3 \mathrm{H}),-0.25(\mathrm{~s}, 3 \mathrm{H}) ;{ }^{13} \mathrm{C} \mathrm{NMR}\left(100 \mathrm{MHz}, \mathrm{CDCl}_{3}\right): \delta 157.6$, 156.0, 135.9, 129.7, 128.7, 128.3, 127.5, 126.0, 119.2, 79.1, 70.5, 70.0, 46.0, 40.6, 28.4, 25.8, 17.9, $-4.9,-5.0$; HRMS (ESI) $m / z$ : calcd. for $\mathrm{C}_{27} \mathrm{H}_{39}{ }^{79} \mathrm{Br}_{2} \mathrm{NNaO}_{4} \mathrm{Si} 650.0907\left[\mathrm{M}+\mathrm{Na}^{+}\right]$found 650.0897 .

\section{Tetrahydroquinoline 41}
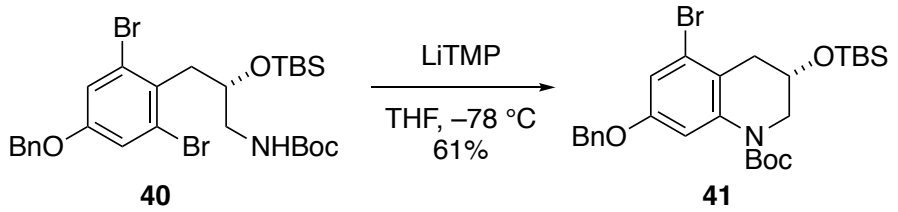

To a solution of carbamate $40(26.4 \mathrm{~g}, 41.9 \mathrm{mmol})$ in THF $(720 \mathrm{~mL})$ was added LiTMP $(1.00$ $\mathrm{M}$ in $n$-hexane and THF, $210 \mathrm{~mL}, 210 \mathrm{mmol}$ ) at $-78{ }^{\circ} \mathrm{C}$. After stirring at $-78{ }^{\circ} \mathrm{C}$ for $10 \mathrm{~min}$, the reaction was quenched with saturated aqueous $\mathrm{NH}_{4} \mathrm{Cl}$, and the mixture was extracted with EtOAc three times. The combined organic extracts were washed with saturated aqueous $\mathrm{NH}_{4} \mathrm{Cl}$ and brine, dried over anhydrous sodium sulfate, and filtered. The organic solvents were removed under reduced pressure to give a crude material, which was purified by silica gel column chromatography (hexanes- $\left.\mathrm{CH}_{2} \mathrm{Cl}_{2}=2: 1\right)$ to afford tetrahydroquinoline $41(13.9 \mathrm{~g}, 25.4 \mathrm{mmol}, 61 \%)$. A colorless solid; $[\alpha]_{\mathrm{D}}{ }^{27}+23.7$ ( $c$ 0.81, $\mathrm{CHCl}_{3}$ ); mp $66-69{ }^{\circ} \mathrm{C}$ (hexanes-EtOAc, colorless prisms); IR (film): $1705,1604,1472,1464,1455,1366,1315,1252,1223,1154,1118,1098,837,775 \mathrm{~cm}^{-1} ;{ }^{1} \mathrm{H} \mathrm{NMR}$ (400 MHz, $\left.\mathrm{CDCl}_{3}\right): \delta 7.43-7.28(\mathrm{~m}, 6 \mathrm{H}), 7.00(\mathrm{~d}, 1 \mathrm{H}, J=2.4 \mathrm{~Hz}), 5.01(\mathrm{~s}, 2 \mathrm{H}), 4.13-4.04(\mathrm{~m}, 1 \mathrm{H})$, $3.89(\mathrm{dd}, 1 \mathrm{H}, J=12.0,3.2 \mathrm{~Hz}), 3.35(\mathrm{dd}, 1 \mathrm{H}, J=12.0,8.0 \mathrm{~Hz}), 2.99(\mathrm{dd}, 1 \mathrm{H}, J=16.8,6.0 \mathrm{~Hz})$, $2.61(\mathrm{dd}, 1 \mathrm{H}, J=16.8,6.8 \mathrm{~Hz}), 1.52(\mathrm{~s}, 9 \mathrm{H}), 0.91(\mathrm{~s}, 9 \mathrm{H}), 0.13(\mathrm{~s}, 6 \mathrm{H}) ;{ }^{13} \mathrm{C} \mathrm{NMR}(100 \mathrm{MHz}$, 
$\left.\mathrm{CDCl}_{3}\right): \delta 156.8,153.4,140.1,136.6,128.6,128.0,127.5,124.7,120.1,115.2,110.2,81.3,70.3$, 65.6, 49.9, 38.2, 28.3, 25.9, 18.2, -4.7, -4.8; HRMS (ESI) $m / z$ : calcd. for $\mathrm{C}_{27} \mathrm{H}_{38}{ }^{79} \mathrm{BrNNaO}_{4} \mathrm{Si}$ $570.1646\left[\mathrm{M}+\mathrm{Na}^{+}\right]$found 570.1638 .

\section{Oxime 44}

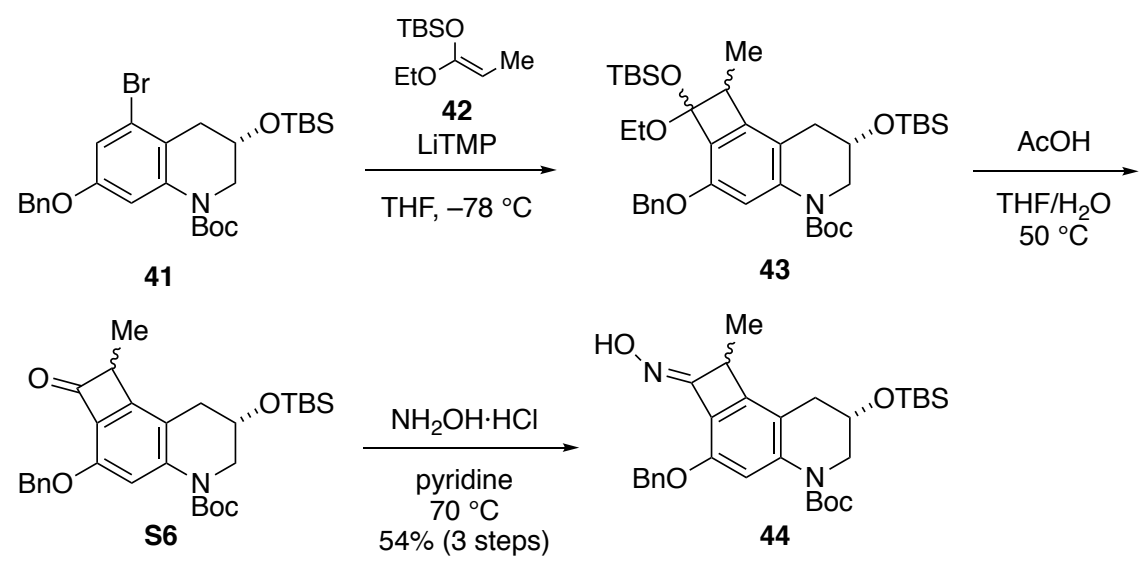

To a solution of bromide $41(190 \mathrm{mg}, 346 \mu \mathrm{mol})$ and ketene silyl acetal 42 (437 $\mu \mathrm{L}, 1.73$ mmol, freshly prepared form propanoic acid ethyl ester $)^{7}$ in THF $(1.4 \mathrm{~mL})$ was added LiTMP $(0.500 \mathrm{M}$ in $n$-hexane and THF, $2.08 \mathrm{~mL}, 1.04 \mathrm{mmol})$ at $-78{ }^{\circ} \mathrm{C}$. After stirring at $-78{ }^{\circ} \mathrm{C}$ for $15 \mathrm{~min}$, the reaction was quenched with $\mathrm{H}_{2} \mathrm{O}$ at $-78{ }^{\circ} \mathrm{C}$, and the mixture was extracted with EtOAc three times. The combined organic extracts were washed with brine, dried over anhydrous sodium sulfate, and filtered. The organic solvents were removed under reduced pressure to give a crude $\mathbf{4 3}$, which was used to the next reaction without further purification. To a solution of the crude $\mathbf{4 3}$ in $\mathrm{THF}$ $(0.34 \mathrm{~mL})$ and $\mathrm{H}_{2} \mathrm{O}(0.34 \mathrm{~mL})$ was added $\mathrm{AcOH}(1.0 \mathrm{~mL})$ at room temperature. After stirring at $50{ }^{\circ} \mathrm{C}$ for $1.5 \mathrm{~h}$, the reaction was quenched with saturated aqueous $\mathrm{NaHCO}_{3}$, and the mixture was extracted with EtOAc three times. The combined organic extracts were washed with saturated aqueous $\mathrm{NaHCO}_{3}$ and brine, dried over anhydrous sodium sulfate, and filtered. The organic solvents were removed under reduced pressure to give a crude S6, which was used to the next reaction without further purification. To a solution of the crude $\mathbf{S 6}$ in pyridine $(3.5 \mathrm{~mL})$ was added hydroxylamine hydrochloride $(63.4 \mathrm{mg}, 912 \mu \mathrm{mol})$ at room temperature. After stirring at $70{ }^{\circ} \mathrm{C}$ for $8 \mathrm{~h}$, the reaction was quenched with $1 \mathrm{M}$ aqueous $\mathrm{HCl}$, and the mixture was extracted with EtOAc three times. The combined organic extracts were washed with $1 \mathrm{M}$ aqueous $\mathrm{HCl}$ and brine, dried over anhydrous sodium sulfate, and filtered. The organic solvents were removed under reduced pressure to give a crude material, which was purified by flash silica gel column chromatography (hexanes-EtAOc $=5: 1)$ to afford oxime $44(102 \mathrm{mg}, 189 \mu \mathrm{mol}, 54 \%, 3$ steps). A colorless solid; $[\alpha]_{\mathrm{D}}{ }^{27}+36.9\left(c 1.73, \mathrm{CHCl}_{3}\right) ; \mathrm{mp} 147-148{ }^{\circ} \mathrm{C}$ (hexanes-EtOAc, colorless prisms); IR (film): 3393 , 2956, 2929, 1714, 1699, 1684, 1488, 1367, 1154, $754 \mathrm{~cm}^{-1} ;{ }^{1} \mathrm{H}$ NMR (400 MHz, $\mathrm{CDCl}_{3}$ ): $\delta 7.43$ (d, $2 \mathrm{H}, J=7.6 \mathrm{~Hz}), 7.38-7.32(\mathrm{~m}, 3 \mathrm{H}), 7.22(\mathrm{~d}, 1 \mathrm{H}, J=8.0 \mathrm{~Hz}), 6.85(\mathrm{br} \mathrm{s}, 1 \mathrm{H}), 5.35(\mathrm{~s}, 2 \mathrm{H}), 4.24-$ $4.15(\mathrm{~m}, 1 \mathrm{H}), 4.14-4.03(\mathrm{~m}, 1 \mathrm{H}), 4.00(\mathrm{dd}, 0.5 \mathrm{H}, J=12.8,2.8 \mathrm{~Hz}), 3.92(\mathrm{dd}, 0.5 \mathrm{H}, J=12.4,2.4$ $\mathrm{Hz}), 3.40(\mathrm{dd}, 0.5 \mathrm{H}, J=12.8,8.4 \mathrm{~Hz}), 3.32(\mathrm{dd}, 0.5 \mathrm{H}, J=12.4,8.4 \mathrm{~Hz}), 2.91(\mathrm{dd}, 0.5 \mathrm{H}, J=4.4,4.4$ $\mathrm{Hz}), 2.87(\mathrm{dd}, 0.5 \mathrm{H}, J=4.8,4.8 \mathrm{~Hz}), 2.58(\mathrm{dd}, 1 \mathrm{H}, J=6.8,6.8 \mathrm{~Hz}), 2.54(\mathrm{dd}, 1 \mathrm{H}, J=6.8,6.8 \mathrm{~Hz})$, $1.57(\mathrm{~d}, 3 \mathrm{H}, J=6.8 \mathrm{~Hz}), 1.51(\mathrm{~s}, 9 \mathrm{H}), 0.91(\mathrm{~s}, 4.5 \mathrm{H}), 0.90(\mathrm{~s}, 4.5 \mathrm{H}), 0.121(\mathrm{~s}, 3 \mathrm{H}), 0.115(\mathrm{~s}, 3 \mathrm{H})$; ${ }^{13} \mathrm{C}$ NMR $\left(100 \mathrm{MHz}, \mathrm{CDCl}_{3}\right): \delta$ 156.2, 153.4, 150.4, 148.5, 142.50, 142.47, 137.2, 128.4, 127.8, 
$127.7,119.13,119.12,115.18,115.19,112.1,112.0,81.40,81.37,71.9,65.11,65.05,50.52,50.47$, $46.5,46.4,32.75,32.65,28.3,25.8,18.2,15.9,15.8,-4.70,-4.73,-4.81,-4.83$; HRMS (ESI) $m / z$ : calcd. for $\mathrm{C}_{30} \mathrm{H}_{43} \mathrm{~N}_{2} \mathrm{O}_{5} \mathrm{Si} 539.2936\left[\mathrm{M}+\mathrm{H}^{+}\right]$, found 539.2935.

\section{Sulfonate 45}
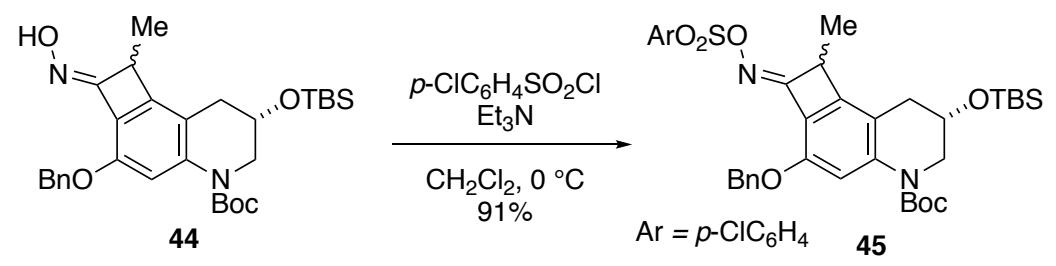

To a solution of oxime $44(201 \mathrm{mg}, 373 \mu \mathrm{mol})$ and $p-\mathrm{ClC}_{6} \mathrm{H}_{4} \mathrm{SO}_{2} \mathrm{Cl}(118 \mathrm{mg}, 560 \mu \mathrm{mol})$ in $\mathrm{CH}_{2} \mathrm{Cl}_{2}(3.7 \mathrm{~mL})$ was added $\mathrm{Et}_{3} \mathrm{~N}(104 \mu \mathrm{L}, 746 \mu \mathrm{mol})$ at $0{ }^{\circ} \mathrm{C}$. After stirring at $0{ }^{\circ} \mathrm{C}$ for $1.5 \mathrm{~h}$, the reaction was quenched with $\mathrm{H}_{2} \mathrm{O}$, and the mixture was extracted with $\mathrm{CH}_{2} \mathrm{Cl}_{2}$ three times. The combined organic extracts were washed with $\mathrm{H}_{2} \mathrm{O}$ and brine, dried over anhydrous sodium sulfate, and filtered. The organic solvents were removed under reduced pressure to give a crude material, which was purified by flash silica gel column chromatography (petroleum ether-acetone $=30: 1$ ) to afford sulfonate 45 (242 mg, $339 \mu \mathrm{mol}, 91 \%)$. A yellow solid; $[\alpha]_{\mathrm{D}}{ }^{27}+12.8\left(c 1.69, \mathrm{CHCl}_{3}\right) ; \mathrm{mp}$ 59-60 ${ }^{\circ} \mathrm{C}$ (hexanes-EtOAc, colorless prisms); IR (film): 1707, 1488, 1370, 1313, 1253, 1228, 1191, 1173, 1153, 1097, 836, 819, 775, $761 \mathrm{~cm}^{-1}$; ${ }^{1} \mathrm{H} \mathrm{NMR}$ (400 MHz, $\left.\mathrm{CDCl}_{3}\right): \delta 7.89$ (d, 2H, J=8.8 Hz), 7.45-7.30 (m, 8H), $5.21(\mathrm{~s}, 2 \mathrm{H}), 4.28-4.20(\mathrm{~m}, 1 \mathrm{H}), 4.15-4.05(\mathrm{~m}, 1 \mathrm{H}), 3.93(\mathrm{dd}, 0.5 \mathrm{H}, J=13.2$, $2.8 \mathrm{~Hz}), 3.84(\mathrm{dd}, 0.5 \mathrm{H}, J=12.8,3.2 \mathrm{~Hz}), 3.46(\mathrm{dd}, 0.5 \mathrm{H}, J=12.4,7.6 \mathrm{~Hz}), 3.38(\mathrm{dd}, 0.5 \mathrm{H}, J=$ $12.4,8.0 \mathrm{~Hz}$ ), 2.83-2.78 (m, 1H), $2.54(\mathrm{dd}, 1 \mathrm{H}, J=6.4,6.4 \mathrm{~Hz}), 2.50$ (dd, 1H, $J=6.4,6.4 \mathrm{~Hz}$ ), $1.57(\mathrm{~d}, 3 \mathrm{H}, J=6.8 \mathrm{~Hz}), 1.50(\mathrm{~s}, 9 \mathrm{H}), 0.89(\mathrm{~s}, 4.5 \mathrm{H}), 0.88(\mathrm{~s}, 4.5 \mathrm{H}), 0.11(\mathrm{~s}, 3 \mathrm{H}), 0.10(\mathrm{~s}, 3 \mathrm{H}) ;{ }^{13} \mathrm{C}$ NMR (100 MHz, $\left.\mathrm{CDCl}_{3}\right): \delta 163.2,153.2,153.1$ 151.6, 148.5, 145.2, 145.1, 140.6, 136.6, 134.0, $130.4,129.2$, 128.5, 128.1, 127.5, 115.54, 115.46, 115.1, 115.0, 112.7, 112.6, 81.81, 81.78, 72.1, 64.6, 64.5, 50.5, 50.4, 47.8, 32.5, 32.4, 28.2, 25.8, 18.1, 16.0, 15.9, -4.76, -4.85; HRMS (ESI) $\mathrm{m} / z$ : calcd. for $\mathrm{C}_{36} \mathrm{H}_{46} \mathrm{ClN}_{2} \mathrm{O}_{7} \mathrm{SSi} 713.2478\left[\mathrm{M}+\mathrm{H}^{+}\right]$found 713.2475 .

\section{Indole 46}
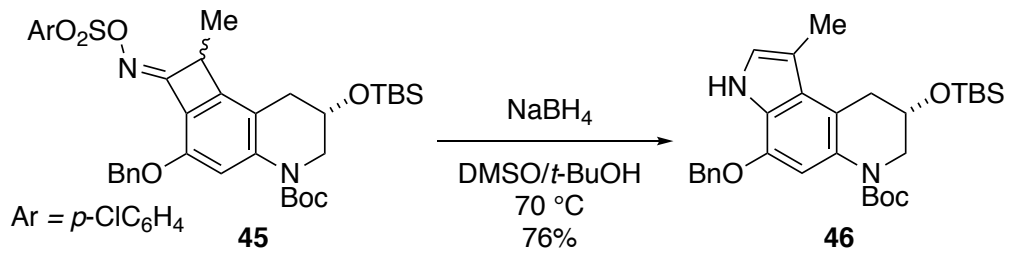

To a solution of sulfonate $\mathbf{4 5}(20.5 \mathrm{mg}, 28.7 \mu \mathrm{mol})$ in DMSO $(0.2 \mathrm{~mL})$ and $t$ - $\mathrm{BuOH}(0.6 \mathrm{~mL})$ was added $\mathrm{NaBH}_{4}(10.9 \mathrm{mg}, 288 \mu \mathrm{mol})$ at room temperature. After stirring at $70{ }^{\circ} \mathrm{C}$ for $2 \mathrm{~h}$, the reaction was quenched with $\mathrm{H}_{2} \mathrm{O}$ at room temperature, and the mixture was extracted with $\mathrm{Et}_{2} \mathrm{O}$ three times. The combined organic extracts were washed with $\mathrm{H}_{2} \mathrm{O}$ and brine, dried over anhydrous sodium sulfate, and filtered. The organic solvents were removed under reduced pressure to give a crude material, which was purified by preparative TLC (toluene) to afford indole 46 (11.4 mg, 21.8 
$\mu \mathrm{mol}, 76 \%$ ). A colorless solid; $[\alpha]_{\mathrm{D}}{ }^{26}+41.7$ ( c 3.87, $\left.\mathrm{CHCl}_{3}\right)$; mp 144-145 ${ }^{\circ} \mathrm{C}$ (hexanes-EtOAc, colorless prisms); IR (film): 2953, 2928, 1698, 1685, 1507, 1457, 1363, 1253, 1189, 1157, 1095, $837 \mathrm{~cm}^{-1} ;{ }^{1} \mathrm{H}$ NMR (400 MHz, $\mathrm{CDCl}_{3}$ ): $\delta 8.05$ (br s, $\left.1 \mathrm{H}\right), 7.47$ (d, 2H, $\left.J=6.8 \mathrm{~Hz}\right), 7.42-7.32(\mathrm{~m}$, $3 \mathrm{H}), 6.98(\mathrm{br} \mathrm{s}, 1 \mathrm{H}), 6.84(\mathrm{~s}, 1 \mathrm{H}), 5.16(\mathrm{~d}, 1 \mathrm{H}, J=11.2 \mathrm{~Hz}), 5.11(\mathrm{~d}, 1 \mathrm{H}, J=11.2 \mathrm{~Hz}), 4.20-4.05$ $(\mathrm{m}, 2 \mathrm{H}), 3.56(\mathrm{dd}, 1 \mathrm{H}, J=16.8,6.8 \mathrm{~Hz}), 3.30-3.22(\mathrm{~m}, 1 \mathrm{H}), 3.07(\mathrm{dd}, 1 \mathrm{H}, J=16.8,8.0 \mathrm{~Hz}), 2.45(\mathrm{~s}$, $3 \mathrm{H}), 1.52(\mathrm{~s}, 9 \mathrm{H}), 0.94(\mathrm{~s}, 9 \mathrm{H}), 0.16(\mathrm{~s}, 3 \mathrm{H}), 0.15(\mathrm{~s}, 3 \mathrm{H}) ;{ }^{13} \mathrm{C} \mathrm{NMR}\left(100 \mathrm{MHz}, \mathrm{CDCl}_{3}\right): \delta 154.2$, $142.8,137.1$ 130.2, 128.6, 128.0, 127.9, 126.0, 124.8, 122.0, 113.8, 112.9, 101.9, 80.3, 70.3, 66.5, 50.5, 35.3, 28.5, 25.9, 18.3, 13.0, -4.6, -4.7; HRMS (ESI) $m / z$ : calcd. for $\mathrm{C}_{30} \mathrm{H}_{43} \mathrm{~N}_{2} \mathrm{O}_{4} \mathrm{Si} 523.2987$ $\left[\mathrm{M}+\mathrm{H}^{+}\right]$found 523.2980 .

\section{Pyrrolotetrahydroquinoline 47}

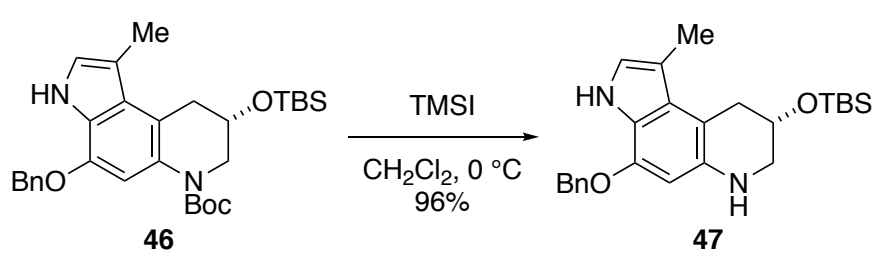

To a solution of carbamate $46(53.8 \mathrm{mg}, 103 \mu \mathrm{mol})$ in $\mathrm{CH}_{2} \mathrm{Cl}_{2}(1.0 \mathrm{~mL})$ was added TMSI $(22.0 \mu \mathrm{L}, 155 \mu \mathrm{mol})$ at $0{ }^{\circ} \mathrm{C}$. After stirring at $0{ }^{\circ} \mathrm{C}$ for $25 \mathrm{~min}$, the reaction was quenched with saturated aqueous $\mathrm{NaHCO}_{3}$, and the mixture was extracted with $\mathrm{CH}_{2} \mathrm{Cl}_{2}$ three times. The combined organic extracts were washed with brine, dried over anhydrous sodium sulfate, and filtered. The organic solvents were removed under reduced pressure to give a crude material, which was purified by flash silica gel column chromatography (hexanes-EtOAc $=3: 1)$ to afford left segment 47 (41.9 mg, 98.9 mmol, 96\%). A brown amorphous; $[\alpha]_{\mathrm{D}^{27}}+56.1$ (c 2.97, $\left.\mathrm{CHCl}_{3}\right) ; \mathrm{mp} 141-143{ }^{\circ} \mathrm{C}$ (hexanes-EtOAc, colorless prisms); IR (film): 2952, 2928, 2856, 1593, 1454, 1147, 1109, 873, 836, $776 \mathrm{~cm}^{-1}$; ${ }^{1} \mathrm{H}$ NMR $\left(400 \mathrm{MHz}, \mathrm{CDCl}_{3}\right): \delta 7.89$ (br s, 1H), 7.44-7.30 (m, 5H), $6.80(\mathrm{~s}, 1 \mathrm{H}), 6.05$ (br s, 1H), 5.09 (br s, 2H), 4.20-4.15 (m, 1H), 3.49 (dd, 1H, d, 1H, $J=16.8,5.6 \mathrm{~Hz}$ ), 3.28 (br, 1H), 3.09-3.00 (m, 2H), 2.44 (s, 3H), $0.93(\mathrm{~s}, 9 \mathrm{H}), 0.13(\mathrm{~s}, 6 \mathrm{H}) ;{ }^{13} \mathrm{C} \mathrm{NMR}\left(100 \mathrm{MHz}, \mathrm{CDCl}_{3}\right)$ : $\delta 144.2$, 137.2, $136.3128 .5,127.9,127.8,127.6,122.2$, 111.9, 104.6, 95.3, 70.1, 66.8, 49.6, 34.5, 25.9, 18.2, $12.8,-4.5,-4.6$ (One signal is missing due to overlap.); HRMS (ESI) $m / z$ : calcd. for $\mathrm{C}_{25} \mathrm{H}_{35} \mathrm{~N}_{2} \mathrm{O}_{2} \mathrm{Si}$ $423.2462\left[\mathrm{M}+\mathrm{H}^{+}\right]$, found 423.2450 .

\section{Amide 48}
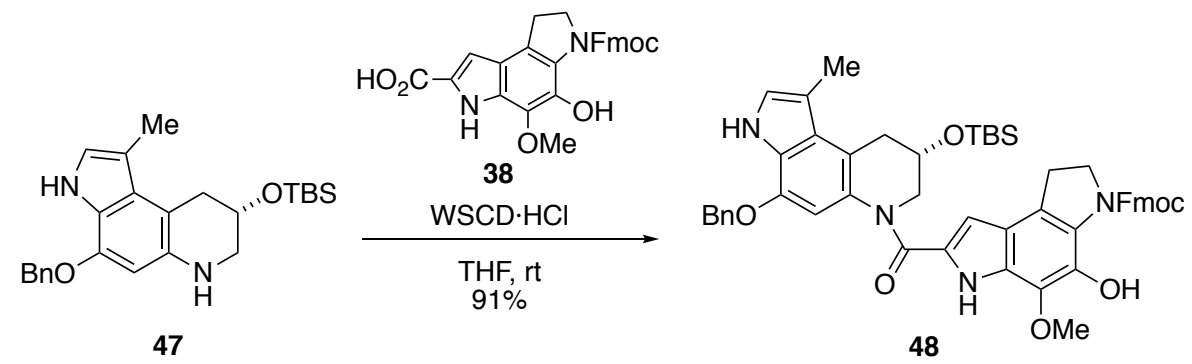

To a solution of left segment $47(50.4 \mathrm{mg}, 119 \mu \mathrm{mol})$, and the carboxylic acid $\mathbf{3 8}(67.3 \mathrm{mg}$, $143 \mu \mathrm{mol})$ in THF $(1.2 \mathrm{~mL})$ was added WSCD $\cdot \mathrm{HCl}(91.4 \mathrm{mg}, 477 \mu \mathrm{mol})$ at room temperature. 
After stirring at room temperature for $10 \mathrm{~h}$, the reaction was quenched with saturated aqueous $\mathrm{NH}_{4} \mathrm{Cl}$, and the mixture was extracted with EtOAc three times. The combined organic extracts were washed with $\mathrm{H}_{2} \mathrm{O}$ and brine, dried over anhydrous sodium sulfate, and filtered. The organic solvents were removed under reduced pressure to give a crude material, which was purified by flash silica gel column chromatography (hexanes-EtOAc $=2: 1)$ to afford amide $48(94.8 \mathrm{mg}, 108$ $\mu$ mol, 91\%). A pale yellow solid; $[\alpha]_{\mathrm{D}}{ }^{24}+16.2\left(c\right.$ 1.28, $\left.\mathrm{CHCl}_{3}\right) ; \mathrm{mp} 139-142{ }^{\circ} \mathrm{C}$ (hexanes-EtOAc, colorless prisms); IR (film): 3456, 3005, 2952, 2928, 2898, 2855, 1663, 1604, 1452, 1353, 1331, 1251, 773, 757, $741 \mathrm{~cm}^{-1}$; ${ }^{1} \mathrm{H}$ NMR $\left(400 \mathrm{MHz}, \mathrm{CDCl}_{3}\right): \delta 11.03(\mathrm{~s}, 1 \mathrm{H}), 8.83(\mathrm{~s}, 1 \mathrm{H}), 8.14(\mathrm{~s}, 1 \mathrm{H})$, $7.79(\mathrm{~d}, 2 \mathrm{H}, J=7.2 \mathrm{~Hz}), 7.61(\mathrm{~d}, 2 \mathrm{H}, J=7.2 \mathrm{~Hz}), 7.42(\mathrm{dd}, 2 \mathrm{H}, J=7.2,7.2 \mathrm{~Hz}), 7.35(\mathrm{dd}, 2 \mathrm{H}, J=$ 7.2, 7.2 Hz), 7.25-7.15 (m, 5H), $6.94(\mathrm{~s}, 1 \mathrm{H}), 6.51(\mathrm{~s}, 1 \mathrm{H}), 6.13(\mathrm{~s}, 1 \mathrm{H}), 4.85(\mathrm{~s}, 2 \mathrm{H}), 4.58(\mathrm{~d}, 2 \mathrm{H}, J$ = 7.2 Hz), 4.38-4.28 (m, 2H), 4.18-4.08 (m, 1H), $4.03(\mathrm{t}, 2 \mathrm{H}, J=8.8 \mathrm{~Hz}), 3.94(\mathrm{~s}, 3 \mathrm{H}), 3.98-3.87$ $(\mathrm{m}, 1 \mathrm{H}), 3.56(\mathrm{dd}, 1 \mathrm{H}, J=16.0,6.4 \mathrm{~Hz}) 3.17(\mathrm{dd}, 1 \mathrm{H}, J=16.0,6.0 \mathrm{~Hz}), 2.98(\mathrm{t}, 2 \mathrm{H}, J=8.8 \mathrm{~Hz})$, $2.52(\mathrm{~s}, 3 \mathrm{H}), 0.83(\mathrm{~s}, 9 \mathrm{H}), 0.10(\mathrm{~s}, 3 \mathrm{H}), 0.06(\mathrm{~s}, 3 \mathrm{H}) ;{ }^{13} \mathrm{C} \mathrm{NMR}\left(100 \mathrm{MHz}, \mathrm{CDCl}_{3}\right): \delta$ 162.6, 155.1, $143.5142 .8,141.3,137.2,136.6,132.8,130.5,130.4,129.2,128.3,127.9,127.3,127.2,126.5$, $125.8,125.2,124.9,122.5,120.1,119.1,117.7,114.9,113.0,106.0,102.7,70.4,68.7,67.3,60.6$, 51.6, 49.3, 47.1, 34.4, 26.8, 25.7, 18.0, 13.0, -4.7, -4.8 (One signal is missing due to overlap.); HRMS (ESI) $m / z$ : calcd. for $\mathrm{C}_{52} \mathrm{H}_{55} \mathrm{~N}_{4} \mathrm{O}_{7} \mathrm{Si} 875.3835\left[\mathrm{M}+\mathrm{H}^{+}\right]$found 875.3806.

\section{Amide 49}
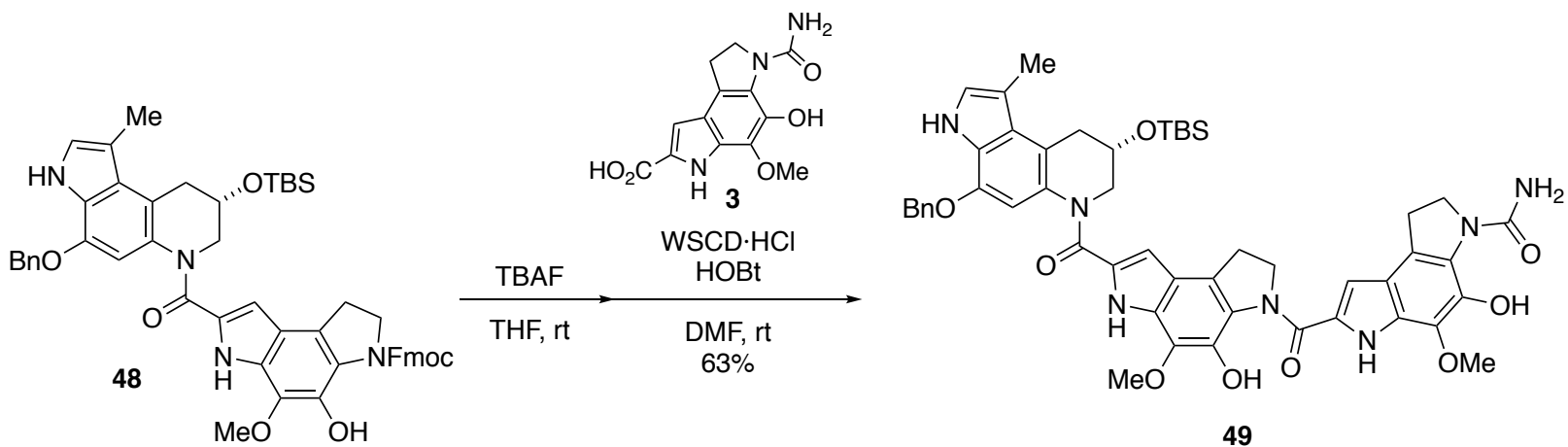

To a solution of $48(34.1 \mathrm{mg}, 39.0 \mu \mathrm{mol})$ in THF $(0.35 \mathrm{~mL})$ was added TBAF (1.0 M in THF, $30 \mu \mathrm{L}, 30 \mu \mathrm{mol}, 30 \mu \mathrm{L}, 30 \mu \mathrm{mol}, 10 \mu \mathrm{L}, 10 \mu \mathrm{mol}, 5 \mu \mathrm{L}, 5 \mu \mathrm{mol}$, addition to every $10 \mathrm{~min}$ ) at room temperature. Then, WSCD. $\mathrm{HCl}(29.9 \mathrm{mg}, 156 \mu \mathrm{mol}), 3(11.4 \mathrm{mg}, 39.0 \mu \mathrm{mol})$ and DMF $(0.7 \mathrm{~mL})$ were added to the mixture at room temperature, and the resulting solution was stirred for $4 \mathrm{~h}$ at room temperature. To the mixture was added $\mathrm{HOBt}(21.0 \mathrm{mg}, 156 \mu \mathrm{mol})$ at room temperature. After stirring at room temperature for $1 \mathrm{~h}$, the reaction was quenched with saturated aqueous $\mathrm{NaHCO}_{3}$, and the mixture was extracted with EtOAc three times. The combined organic extracts were washed with $\mathrm{H}_{2} \mathrm{O}$ twice and brine, dried over anhydrous sodium sulfate, and filtered. The organic solvents were removed under reduced pressure to give a crude material, which was purified by preparative TLC (EtOAc-MeOH-10\% aqueous ammonium hydroxide = 10:1:1) to afford 49 (22.7 $\mathrm{mg}, 24.5$ $\mu \mathrm{mol}, 63 \%$ ). A yellow solid; $[\alpha]_{\mathrm{D}}{ }^{27}+18$ (c 0.65, DMF); mp $172-174{ }^{\circ} \mathrm{C}$ (hexanes-EtOAc, colorless prisms); IR (film): 3344, 2952, 2931, 1733, 1652, 1645, 1634, 1614, 1575, 1568, 1515, 1463, 1456, 1443, 1421, 1331, 1250, $547 \mathrm{~cm}^{-1}$; ${ }^{1} \mathrm{H}$ NMR (400 MHz, acetone- $\left.d_{6}\right): \delta 12.82(\mathrm{~s}, 1 \mathrm{H}), 10.92(\mathrm{br} \mathrm{s}$, $1 \mathrm{H}), 10.28$ (br s, 1H), 10.10 (br s, 1H), 10.04 (br s, 1H), 7.36-7.16 (m, 5H), 7.05-7.00 (m, 2H), $6.53(\mathrm{~s}, 1 \mathrm{H}), 6.30(\mathrm{br} \mathrm{s}, 1 \mathrm{H}), 6.25(\mathrm{br} \mathrm{s}, 2 \mathrm{H}), 4.83(\mathrm{~s}, 2 \mathrm{H}), 4.65(\mathrm{t}, 2 \mathrm{H}, J=8.0 \mathrm{~Hz}), 4.47-4.38(\mathrm{~m}$, 
$1 \mathrm{H}), 4.16(\mathrm{t}, 2 \mathrm{H}, J=8.4 \mathrm{~Hz}), 4.09(\mathrm{dd}, 1 \mathrm{H}, J=11.2,2.8 \mathrm{~Hz}), 4.00-3.90(\mathrm{~m}, 1 \mathrm{H}), 3.92(\mathrm{~s}, 3 \mathrm{H}), 3.88$ (s, 3H), $3.60(\mathrm{dd}, 1 \mathrm{H}, J=16.8,6.0 \mathrm{~Hz}), 3.29(\mathrm{t}, 2 \mathrm{H}, J=8.4 \mathrm{~Hz}), 3.20-3.10(\mathrm{~m}, 3 \mathrm{H}), 2.48(\mathrm{~s}, 3 \mathrm{H})$, $0.85(\mathrm{~s}, 9 \mathrm{H}), 0.14(\mathrm{~s}, 3 \mathrm{H}), 0.08(\mathrm{~s}, 3 \mathrm{H}) ;{ }^{13} \mathrm{C} \mathrm{NMR}\left(100 \mathrm{MHz}\right.$, acetone- $\left.d_{6}\right): \delta 163.3,161.3,158.5$, $143.8,139.7,139.2$, 138.2, 134.3, 133.5, 132.7, 131.3, 131.1, 130.6, 130.0, 129.0, 128.8, 128.4, $128.3,128.1,127.6,126.6,124.2,121.3,119.2,118.62,118.60,114.9,112.8,106.9,105.9,103.2$, $70.7,68.0,60.6,60.4,53.9,52.0,50.3,35.2,28.4,27.4,26.2,18.6,13.2,-4.5,-4.6$; HRMS (ESI) $\mathrm{m} / z$ : calcd. for $\mathrm{C}_{50} \mathrm{H}_{56} \mathrm{~N}_{7} \mathrm{O}_{9} \mathrm{Si} 926.3903\left[\mathrm{M}+\mathrm{H}^{+}\right]$found 926.3911.

\section{Mesylate 50}

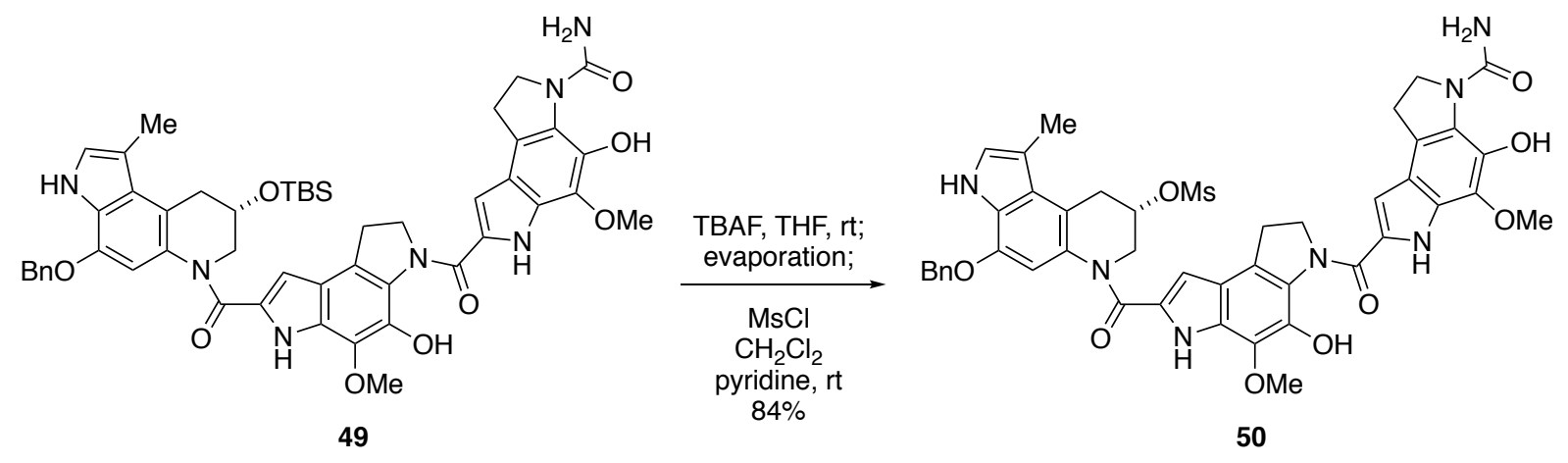

To a solution of $49(17.4 \mathrm{mg}, 18.8 \mu \mathrm{mol})$ in THF $(0.2 \mathrm{~mL})$ was added TBAF (1.0 M in THF, $22.5 \mu \mathrm{L}, 22.5 \mu \mathrm{mol})$ at room temperature. After stirring at room temperature for $15 \mathrm{~min}$, TBAF (1.0 $\mathrm{M}$ in THF, $22.5 \mu \mathrm{L}, 22.5 \mu \mathrm{mol}$ ) was added to the reaction mixture at room temperature, and the resulting mixture was stirred for $3 \mathrm{~h}$ at room temperature. THF was removed under reduced pressure, and the residue was dissolved in a mixture of $\mathrm{CH}_{2} \mathrm{Cl}_{2}(0.2 \mathrm{~mL})$ and pyridine $(30.4 \mu \mathrm{L}, 376$ $\mu \mathrm{mol})$. To the mixture was added $\mathrm{MsCl}(14.6 \mu \mathrm{L}, 188 \mu \mathrm{mol})$ at $0{ }^{\circ} \mathrm{C}$, and the resulting mixture was stirred for $40 \mathrm{~min}$ at room temperature. To the mixture were added pyridine $(30.4 \mu \mathrm{L}, 376 \mu \mathrm{mol})$ and $\mathrm{MsCl}(14.6 \mu \mathrm{L}, 188 \mu \mathrm{mol})$ at room temperature. After stirring at room temperature for $3.5 \mathrm{~h}$, the reaction was quenched with $\mathrm{H}_{2} \mathrm{O}$, and the mixture was extracted with EtOAc four times. The combined organic extracts were washed with brine, dried over anhydrous sodium sulfate, and filtered. The organic solvents were removed under reduced pressure to give a crude material, which was purified by preparative TLC (EtOAc-MeOH-10\% aqueous ammonium hydroxide $=10: 1: 1$ ) to afford 50 (14.1 mg, $15.8 \mu \mathrm{mol}, 84 \%)$. A yellow solid; $[\alpha]_{\mathrm{D}}{ }^{26}-21$ (c 0.27, DMF); mp 219-220 ${ }^{\circ} \mathrm{C}$, decomposition, (hexanes-THF, colorless prisms); IR (film): 3353, 2917, 2848, 1634, 1417, 1328, 1171, 1154, 1123, $746 \mathrm{~cm}^{-1}$; ${ }^{1} \mathrm{H}$ NMR (400 MHz, acetone- $\left.d_{6}\right): \delta 12.81(\mathrm{~s}, 1 \mathrm{H}), 10.94(\mathrm{~s}, 1 \mathrm{H}), 10.25$ (br s, 1H), 10.23-10.13 (m, 2H), 7.30-7.10 (m, 5H), 7.10-7.00 (m, 2H), 6.54 (s, 1H), 6.30-6.20 (m, $1 \mathrm{H}), 6.13(\mathrm{br} \mathrm{s}, 2 \mathrm{H}), 5.45-5.35(\mathrm{~m}, 1 \mathrm{H}), 4.86(\mathrm{~s}, 2 \mathrm{H}), 4.65(\mathrm{t}, 2 \mathrm{H}, J=8.0 \mathrm{~Hz}), 4.42(\mathrm{dd}, 1 \mathrm{H}, J=$ 13.2, $4.4 \mathrm{~Hz}), 4.17(\mathrm{~m}, 3 \mathrm{H}), 3.92(\mathrm{~s}, 3 \mathrm{H}), 3.90(\mathrm{~s}, 3 \mathrm{H}), 3.76(\mathrm{dd}, 1 \mathrm{H}, J=17.2,6.0 \mathrm{~Hz}), 3.55(\mathrm{dd}, 1 \mathrm{H}$, $J=17.2,4.4 \mathrm{~Hz}), 3.31(\mathrm{t}, 2 \mathrm{H}, J=8.8 \mathrm{~Hz}), 3.16(\mathrm{~m}, 2 \mathrm{H}), 2.98(\mathrm{~s}, 3 \mathrm{H}), 2.49(\mathrm{~s}, 3 \mathrm{H}) ;{ }^{13} \mathrm{C} \mathrm{NMR}(100$ $\mathrm{MHz}$, acetone- $\left.d_{6}\right): \delta 163.3,161.4,158.5,144.2,139.7,139.4,138.1,134.3,133.6,132.1,131.3$, $130.6,130.0,129.0,128.8,128.5,128.4,128.1,127.4,126.8,124.5,121.4,119.2,118.6,113.3$, $112.7,106.9,106.2,103.0,77.1,70.7,60.6,60.4,53.9,50.3,49.2,43.4,38.4,31.6,28.4,27.5,13.0$ (One signal is missing due to overlap); HRMS (ESI) $\mathrm{m} / z$ : calcd. for $\mathrm{C}_{45} \mathrm{H}_{44} \mathrm{~N}_{7} \mathrm{O}_{11} \mathrm{~S} 890.2814$ $\left[\mathrm{M}+\mathrm{H}^{+}\right]$found 890.2786 . 
<smiles></smiles>

50

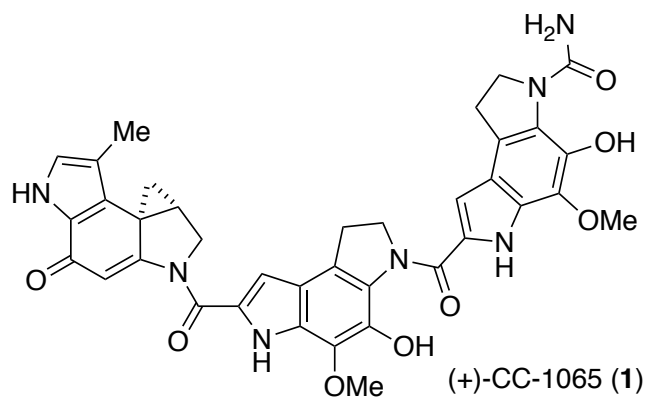

$[\alpha]_{D}^{26}=+85($ c 0.10, DMF)

lit. $[\alpha]_{D}^{23}=+90(\mathrm{c} 0.059, \mathrm{DMF})^{\text {ref. } 8}$

A solution of $\mathbf{5 0}(9.3 \mathrm{mg}, 10 \mu \mathrm{mol})$ and palladium hydroxide on activated carbon (Pd 20\%, wetted with ca. $\left.50 \% \mathrm{H}_{2} \mathrm{O}, 14.7 \mathrm{mg}\right)$ in $\mathrm{THF}(0.2 \mathrm{~mL})$ was stirred under hydrogen atmosphere (1 atm). After stirring at room temperature for $20 \mathrm{~min}, \mathrm{Et}_{3} \mathrm{~N}(22.5 \mu \mathrm{L}, 161 \mu \mathrm{mol})$ was added to the mixture at room temperature. After stirring at room temperature for $1 \mathrm{~h}$, palladium hydroxide on activated carbon was removed by filtration through a pad of Celite ${ }^{\circledR}$, and filtrate was concentrated under reduced pressure to give a crude material, which was purified by preparative TLC (EtOAc-MeOH-10\% aqueous ammonium hydroxide = 10:1:1) to afford $\mathbf{1}$ (2.4 mg, $3.4 \mu \mathrm{mol}, 34 \%$ ). A yellow solid; $[\alpha]_{\mathrm{D}}{ }^{26}+85$ (c 0.10, DMF); mp 225-226 ${ }^{\circ} \mathrm{C}$, decomposition, (hexanes-THF, colorless prisms); IR (film): 3273, 2917, 2848, 1632, 1600, 1576, 1540, 1465, 1441, 1417, 1397 , 1374, 1302, 1265, $1120 \mathrm{~cm}^{-1}$; ${ }^{1} \mathrm{H}$ NMR (400 MHz, DMSO- $\left.d_{6}\right): \delta 12.9(\mathrm{~s}, 1 \mathrm{H}), 11.7(\mathrm{~s}, 1 \mathrm{H}), 11.5(\mathrm{~s}$, $1 \mathrm{H}), 11.4(\mathrm{~s}, 1 \mathrm{H}), 11.04(\mathrm{~s}, 1 \mathrm{H}), 7.06(\mathrm{~m}, 2 \mathrm{H}), 6.87(\mathrm{~m}, 3 \mathrm{H}), 6.43(\mathrm{~s}, 1 \mathrm{H}), 4.68(\mathrm{t}, 2 \mathrm{H}, J=8.0 \mathrm{~Hz})$, $4.43(\mathrm{dd}, 1 \mathrm{H}, J=10.8,5.2 \mathrm{~Hz}), 4.33(\mathrm{~d}, 1 \mathrm{H}, J=10.8 \mathrm{~Hz}), 4.03(\mathrm{t}, 2 \mathrm{H}, J=8.8 \mathrm{~Hz}), 3.85(\mathrm{~s}, 3 \mathrm{H})$, $3.81(\mathrm{~s}, 3 \mathrm{H}), 3.30-3.10(\mathrm{~m}, 5 \mathrm{H}), 1.99(\mathrm{~m}, 4 \mathrm{H}), 1.44(\mathrm{~m}, 1 \mathrm{H}) ;{ }^{13} \mathrm{C}$ NMR (100 MHz, DMSO- $\left.d_{6}\right)$ : $\delta 176.4,161.2$, 160.7 160.3, 157.5, 138.4, 138.0, 133.0, 132.3, 130.7, 130.4, 129.5, 129.0, 128.8, $127.5,127.3,123.5,121.3,118.2,117.7,117.3,113.0,110.6,106.3,105.9,60.3,60.0,54.8,53.4$, 49.4, 31.5, 27.6, 26.5, 21.2, 20.9, 9.6 (One signal is missing due to overlap); HRMS (ESI) $\mathrm{m} / \mathrm{z}$ : calcd. for $\mathrm{C}_{37} \mathrm{H}_{34} \mathrm{~N}_{7} \mathrm{O}_{8} 704.2463\left[\mathrm{M}+\mathrm{H}^{+}\right]$found 704.2433. Spectroscopic data were identical with those previously reporetd. ${ }^{8}$ 


\section{Acidic or basic hydrolysis of Pyrroloindole 9}
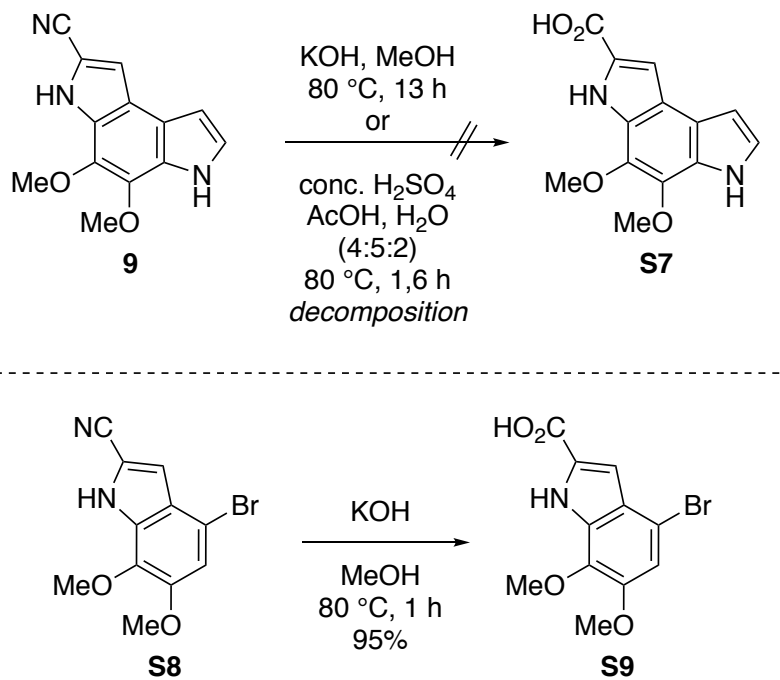

S8

S9

Hydrolysis of pyrroloindole 9 under basic $\left(\mathrm{KOH}, \mathrm{MeOH}, 80{ }^{\circ} \mathrm{C}\right.$ ) or acidic (conc. $\mathrm{H}_{2} \mathrm{SO}_{4}$, $\mathrm{AcOH}, \mathrm{H}_{2} \mathrm{O}$ ) condition caused decomposition. These results suggested that electron rich nature of unprotected pyrroloindole skeleton would contribute to oxidative degradation. In contrast, hydrolysis of 2-cyanoindole S8 possessing electron withdrawing $\mathrm{Br}$ group at $\mathrm{C} 4$ position cleanly furnished carboxylic acid $\mathbf{S 9}$ in $95 \%$ yield.

\section{References}

1) Tsujiyama, S.; Suzuki, K. Org. Synth. 2007, 84, 272-284.

2) Ueda, H.; Satoh, H.; Matsumoto, K.; Sugimoto, K.; Fukuyama, T.; Tokuyama, H. Angew. Chem. Int. Ed. 2009, 48, 7600-7603.

3) Reynes, M.; Dautel, O. J.; Virieux, D.; Flot, D.; Moreau, J. J. E. CrystEngComm 2011, 13, 6050-6056.

4) McElvain, S. M.; Kundiger, D. Org. Synth. 1943, 23, 45-47.

5) Okano, K. Mitsuhashi, N. Tokuyama, H. Tetrahedron. 2013, 69, 10946-10954.

6) (a) Yamada, K.; Kurokawa, T.; Tokuyama, H.; Fukuyama, T. J. Am. Chem. Soc. 2003, 125, 6630-6631. (b) Okano, K.; Tokuyama, H.; Fukuyama, T. J. Am. Chem. Soc. 2006, 128, 71367137.

7) Hosoya, T.; Hasegawa, T.; Kuriyama, Y.; Matsumoto, T.; Suzuki, K. Synlett 1995, 177-179.

8) Boger, D. L.; Coleman, R. S. J. Am. Chem. Soc. 1988, 110, 1321-1323. 

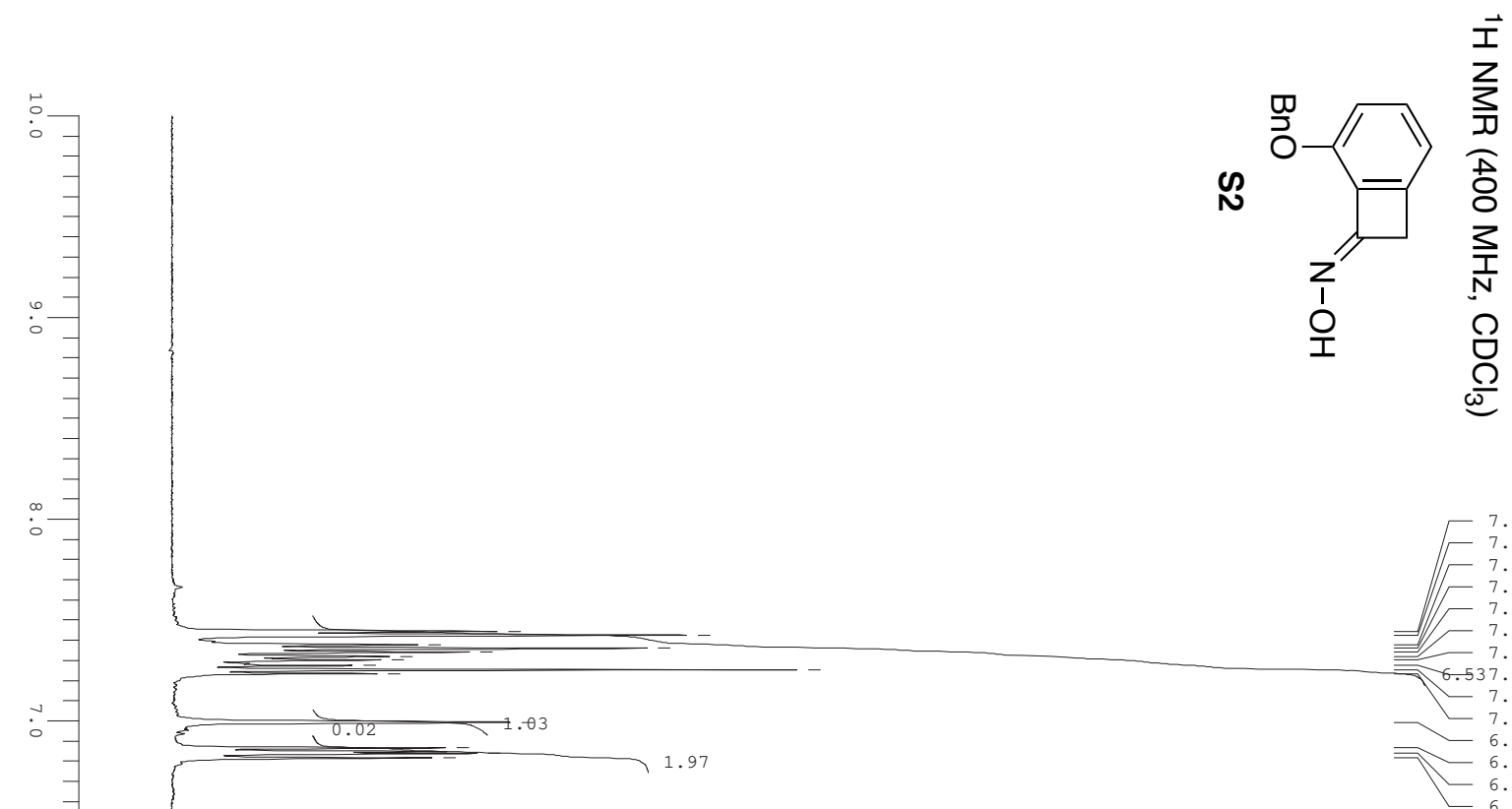

6.537 .276
$-\quad 7.254$

7.254
7.236

6.994

6.867

6.8679
6.817

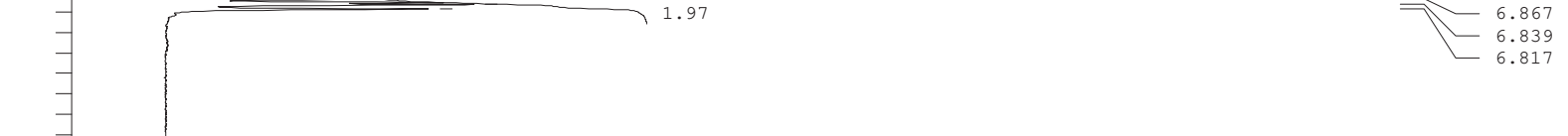

$:-$

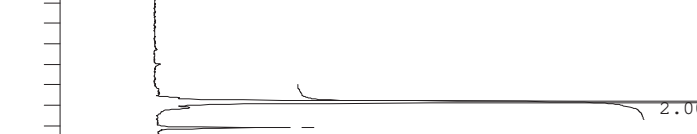

5.419

$:-$

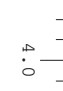

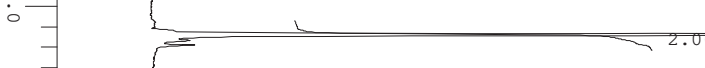

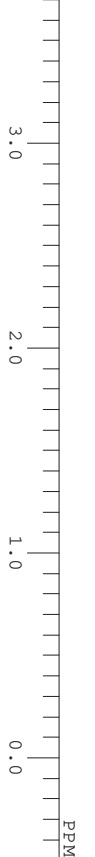




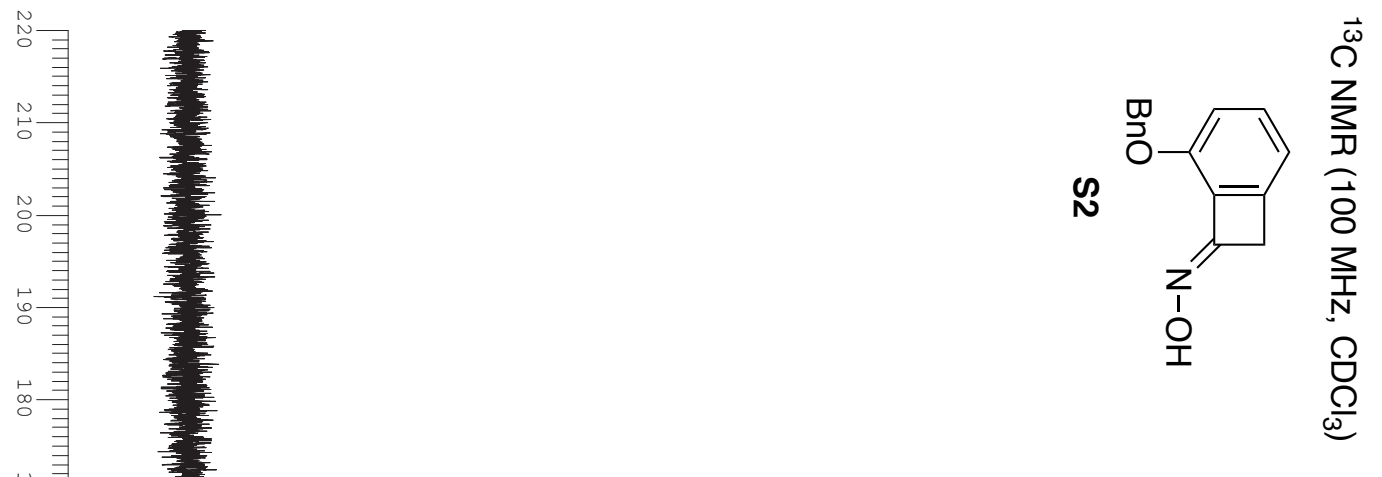
151.720 145.084 $-136.868$ 133.419 128.446 127.944 127.631

116.122 115.513

38.043

77.313

\section{列}



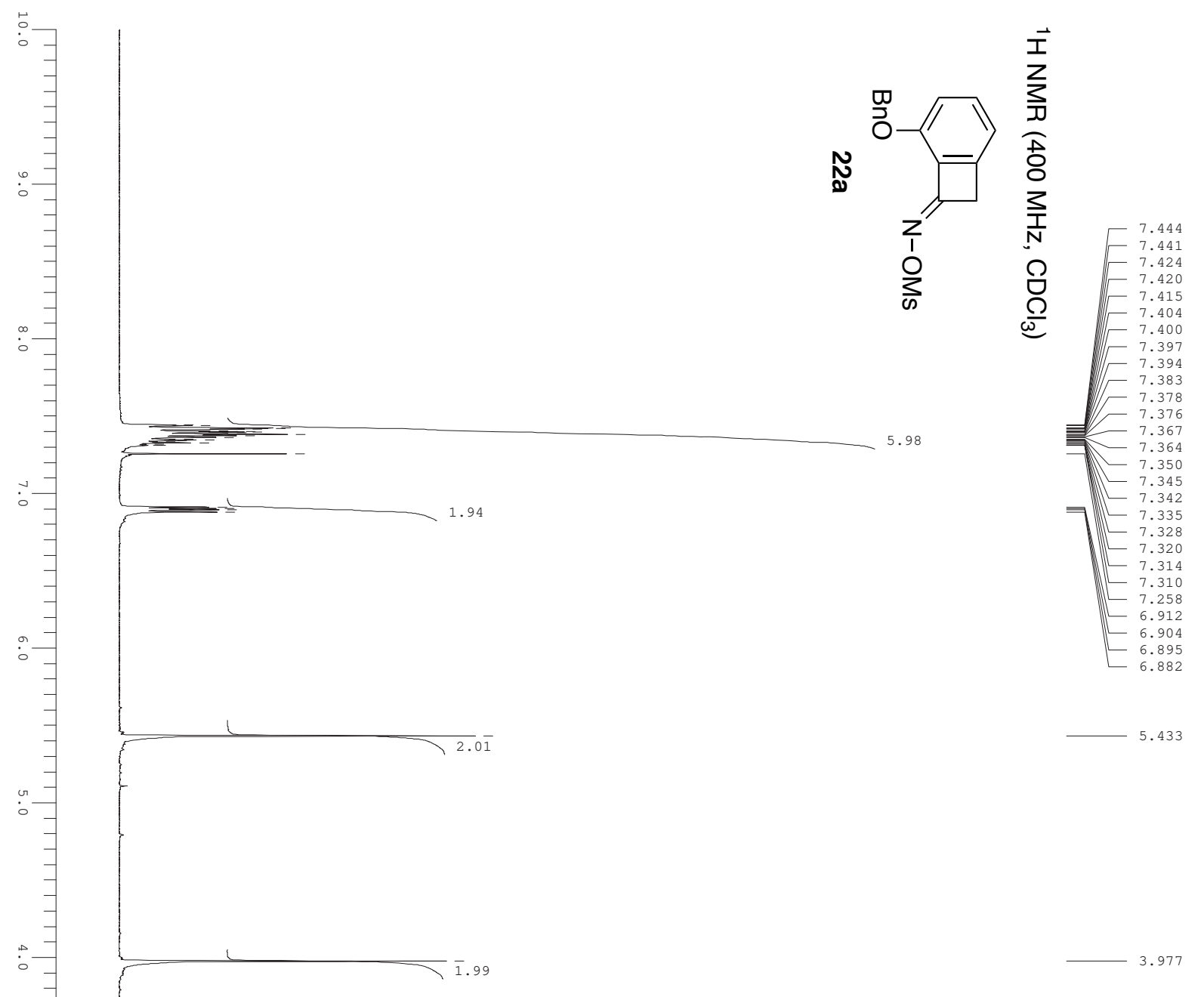

:-

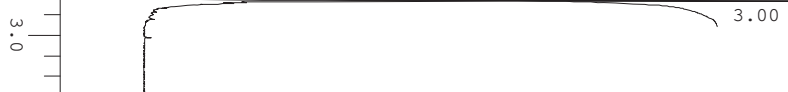




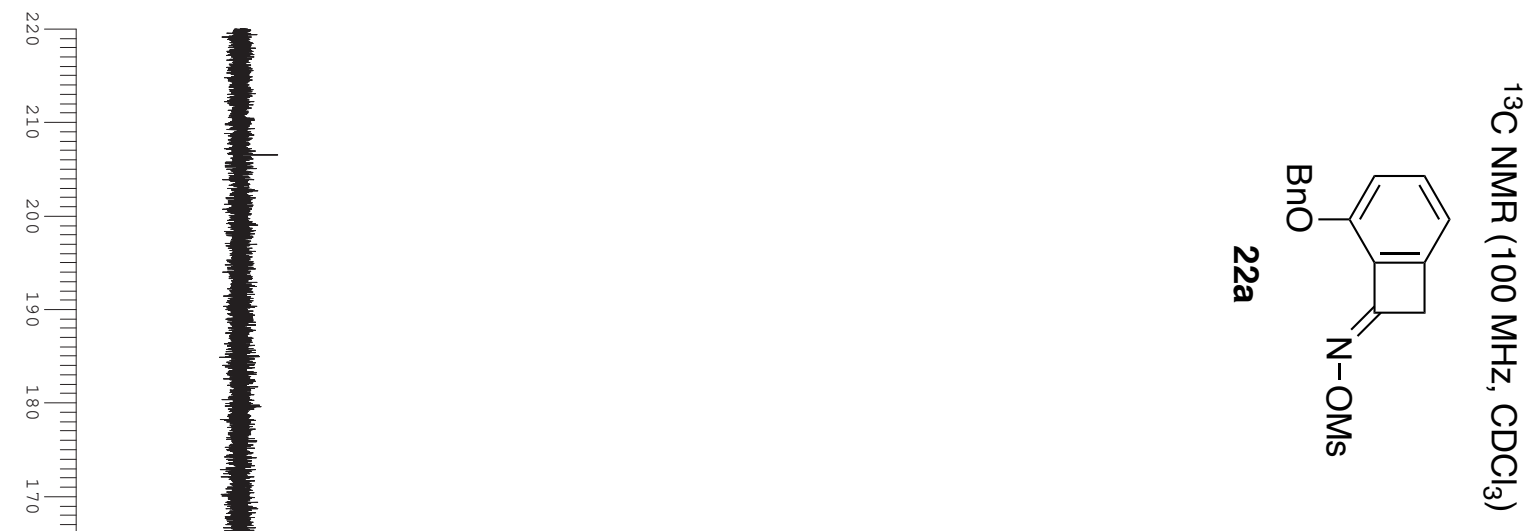

$-160.988$

145.186

136.405
136.224

28.595 128.191 127.459 122.315 116.891 115.673
114.217 

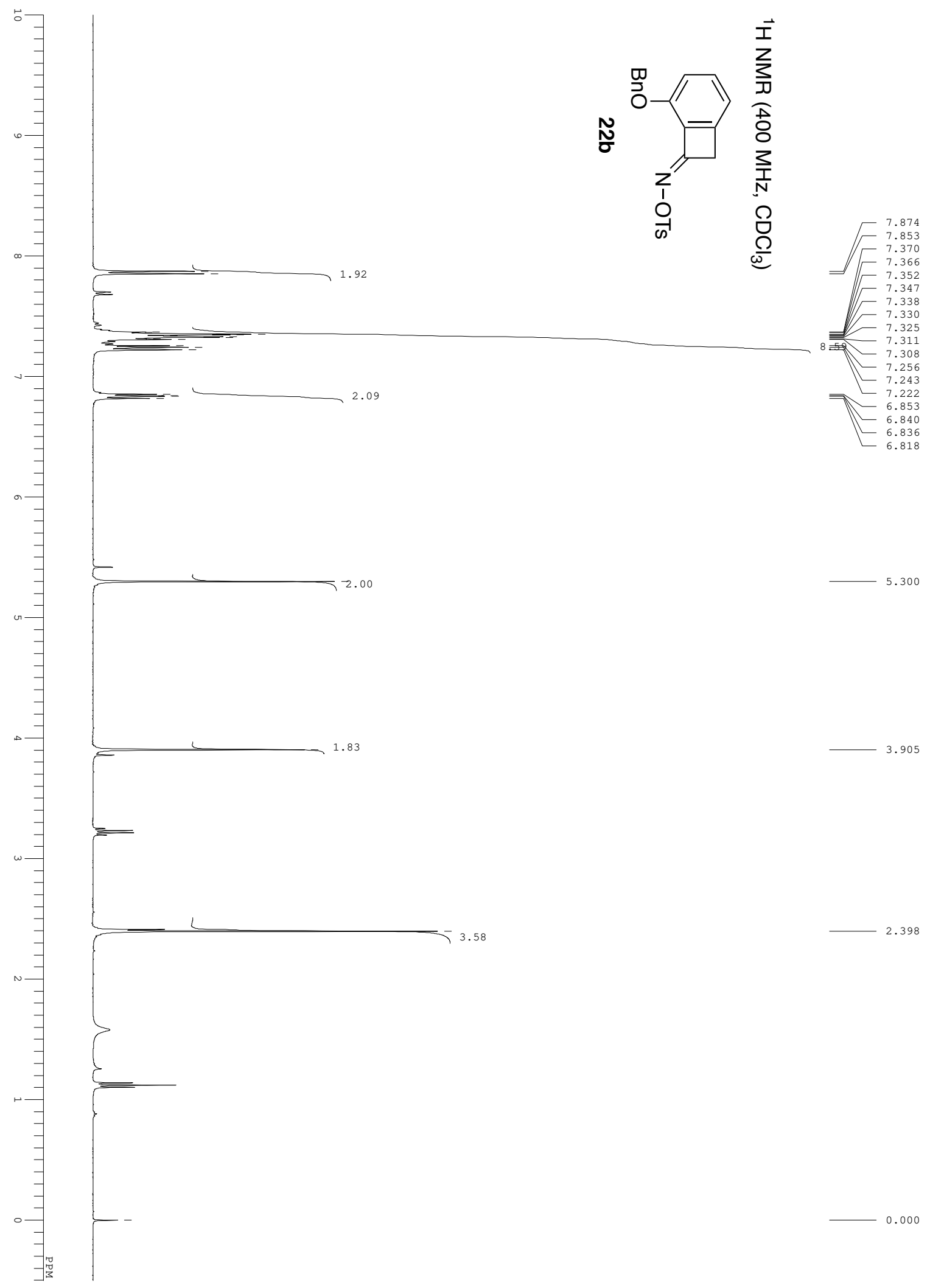


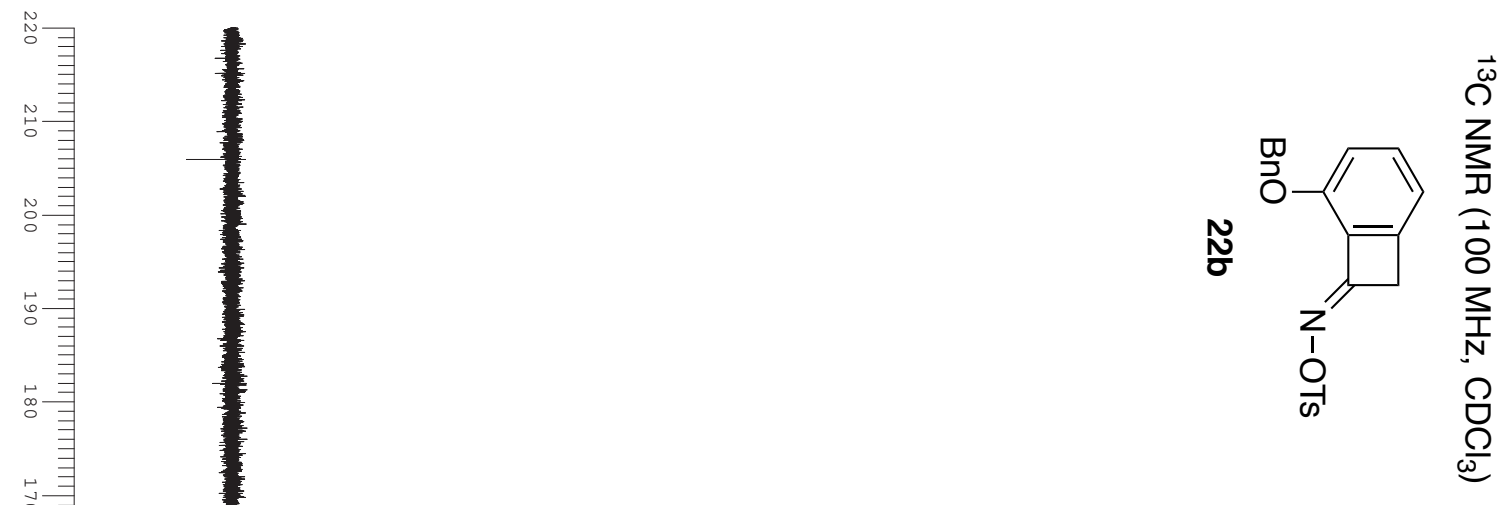

77.321

77.000
76.679 

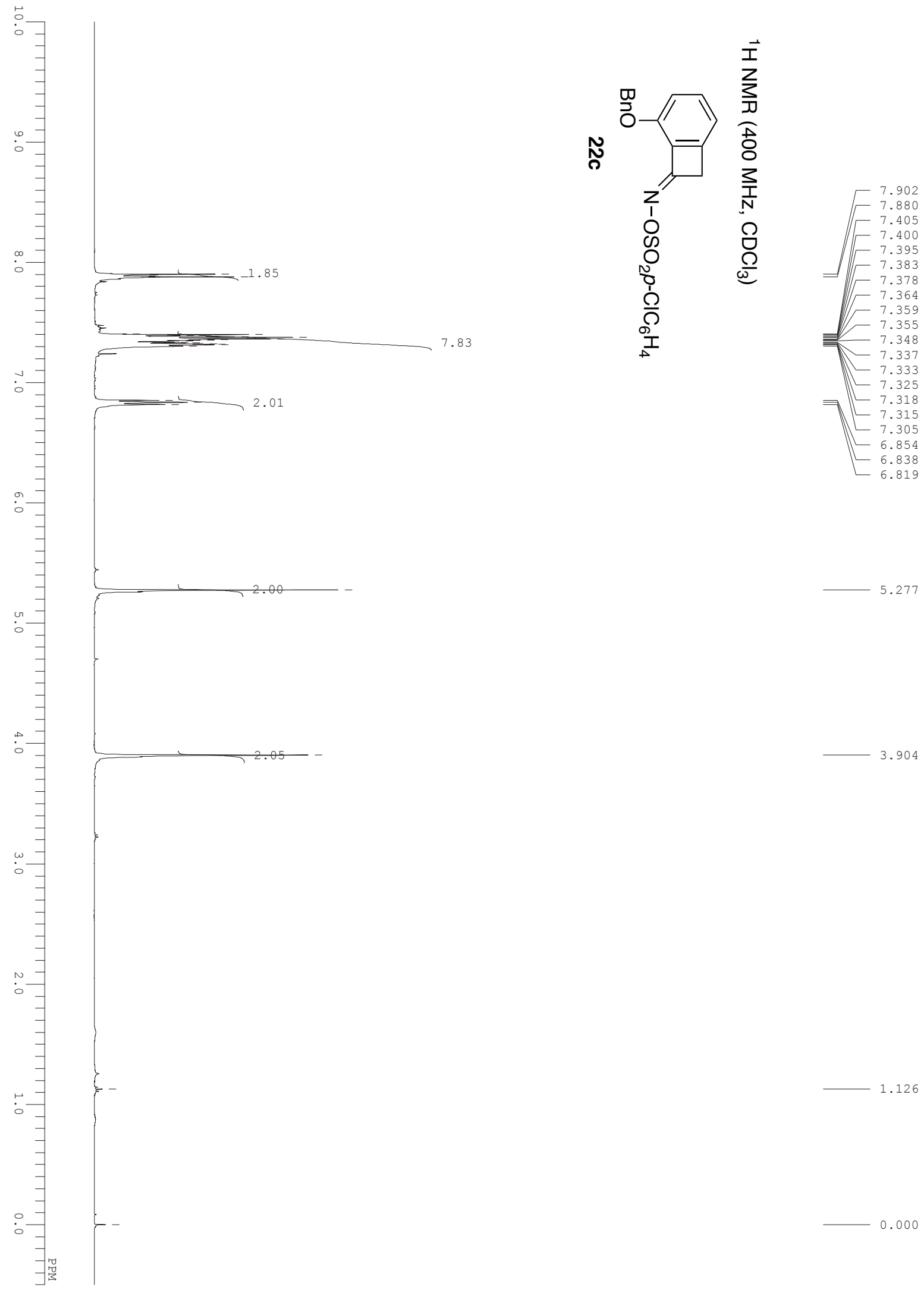


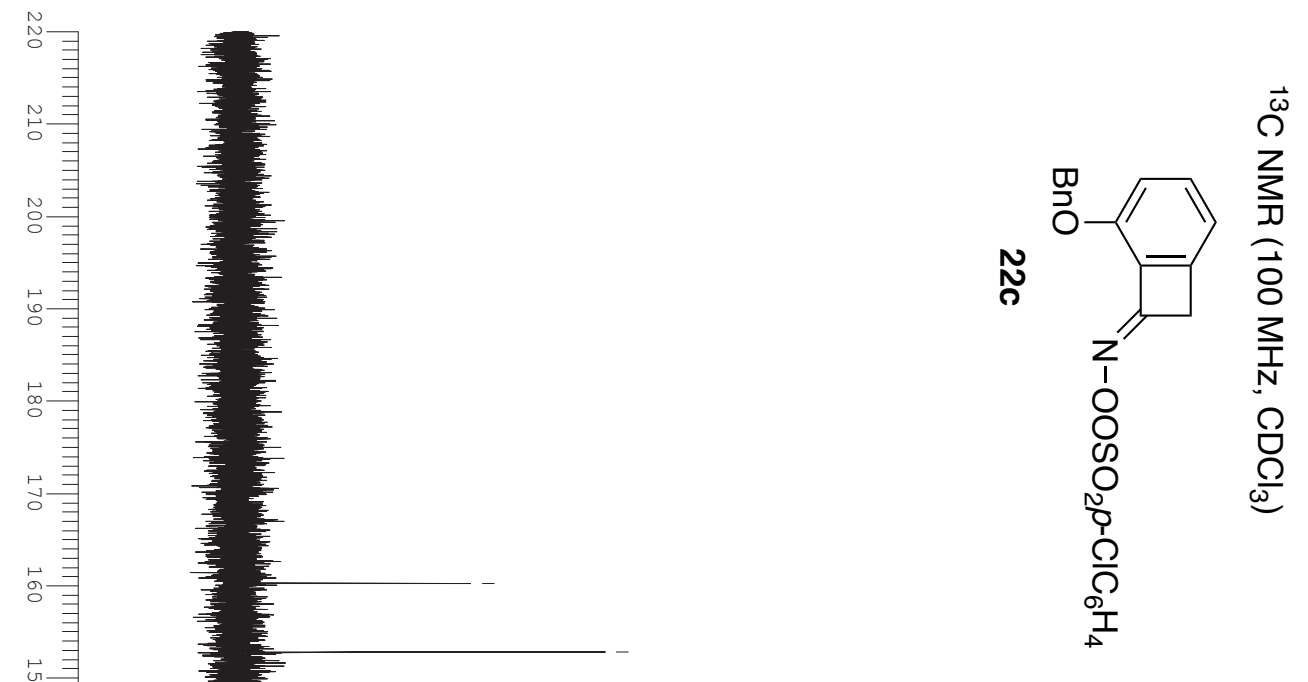

160.290

152.831

144.969

136.201

136.045

133.814

130.373

129.212
128.537

128.249

127.508

117.126

117.045
115.54

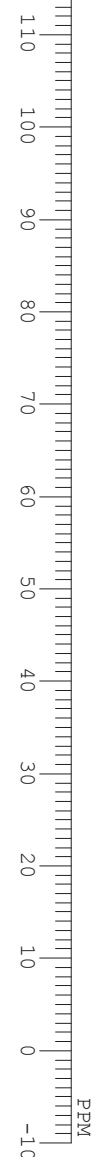

77.313

77.000 76.679
72.159 


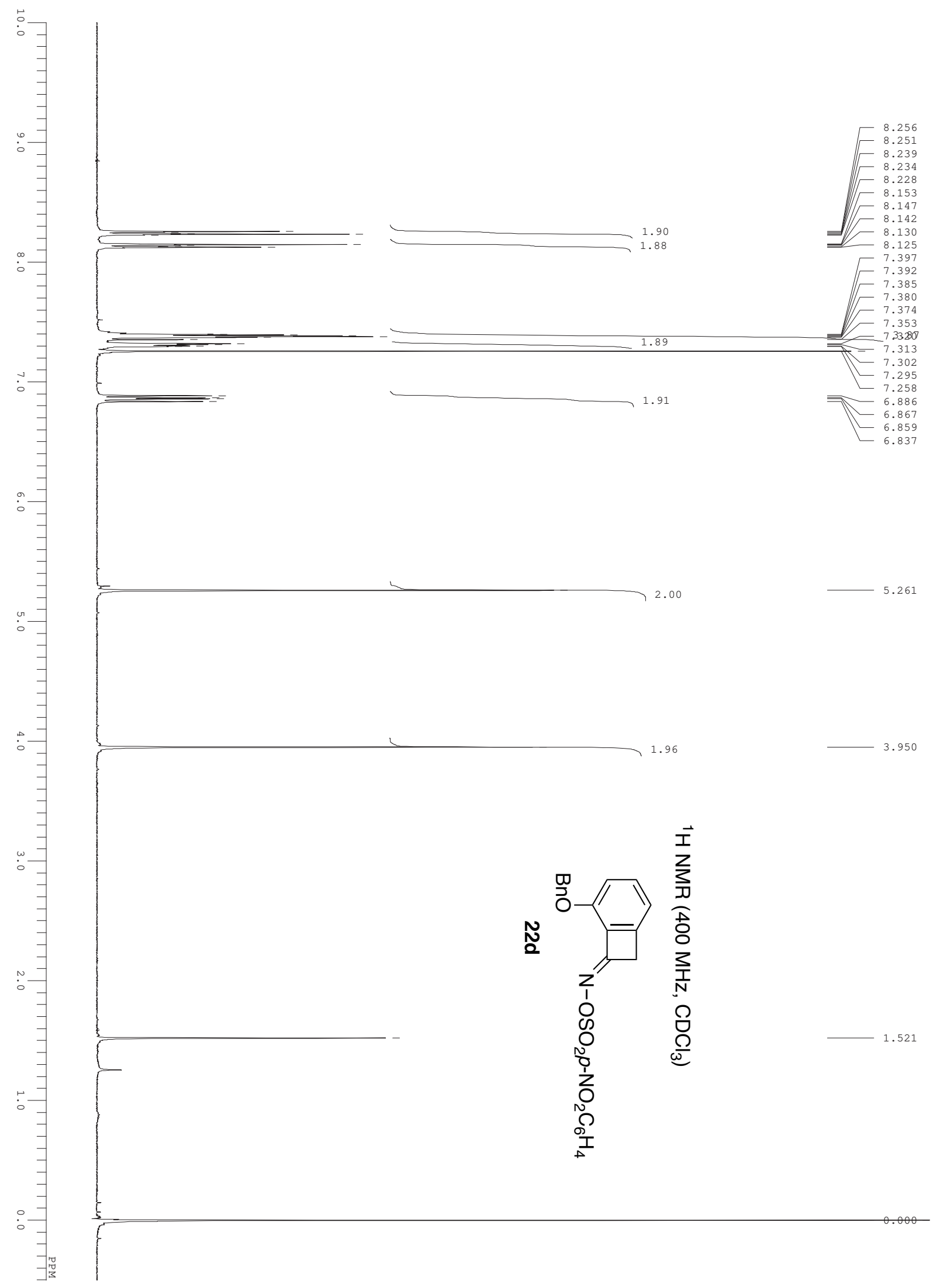




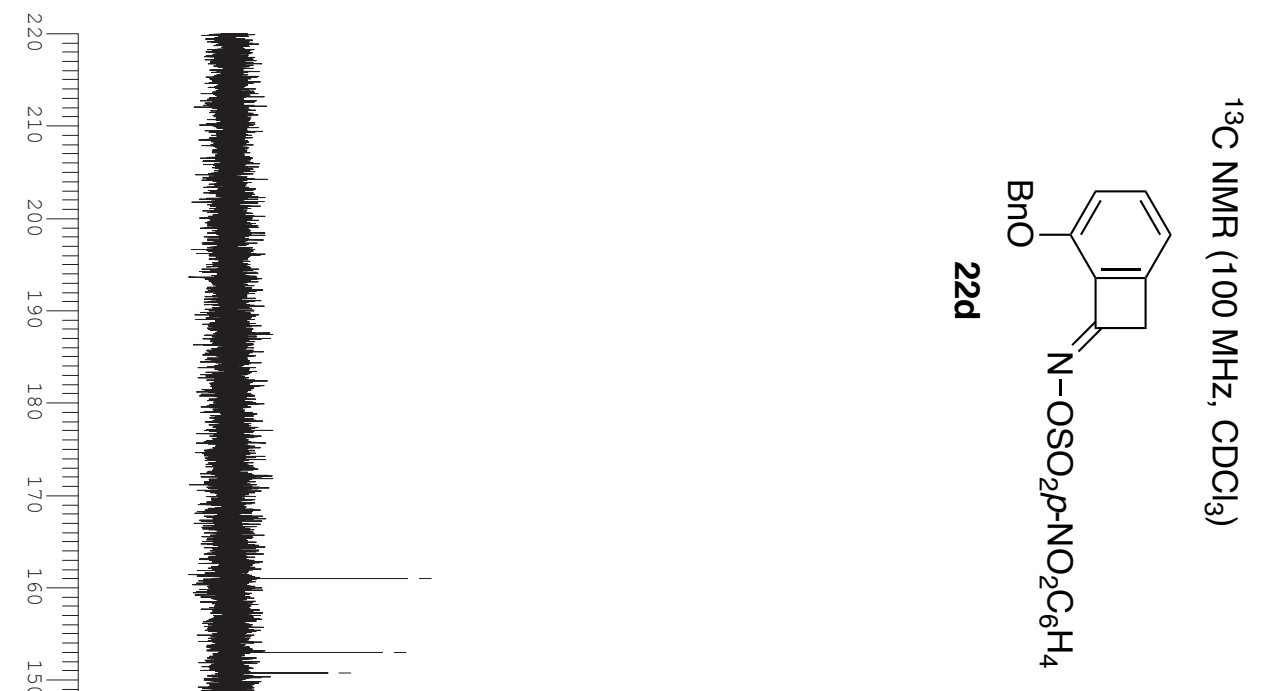

161.013

153.030 144.964 141.088 136.076 130.389 128.677 128.496 127.533 124.027 121.887 117.048 

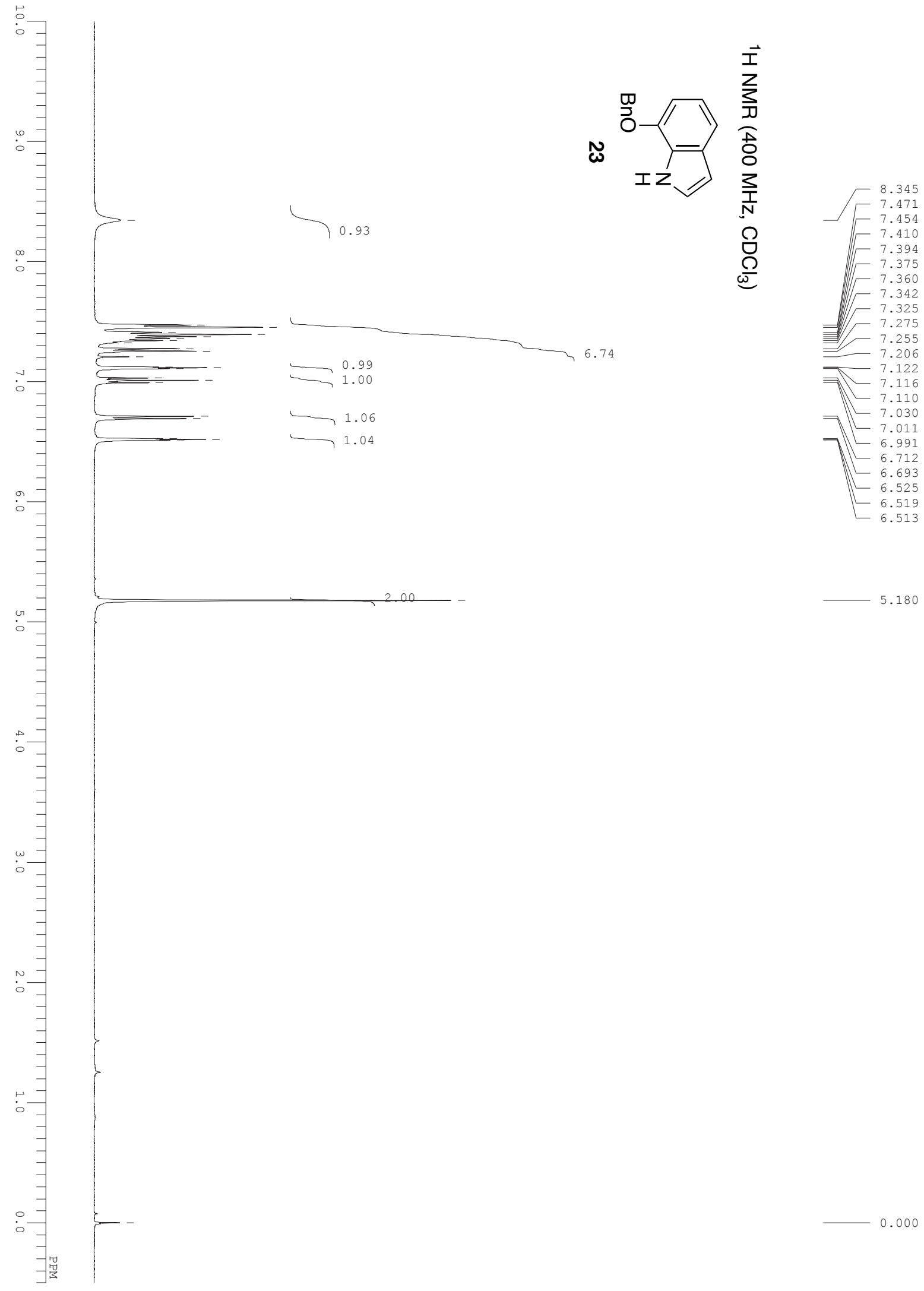


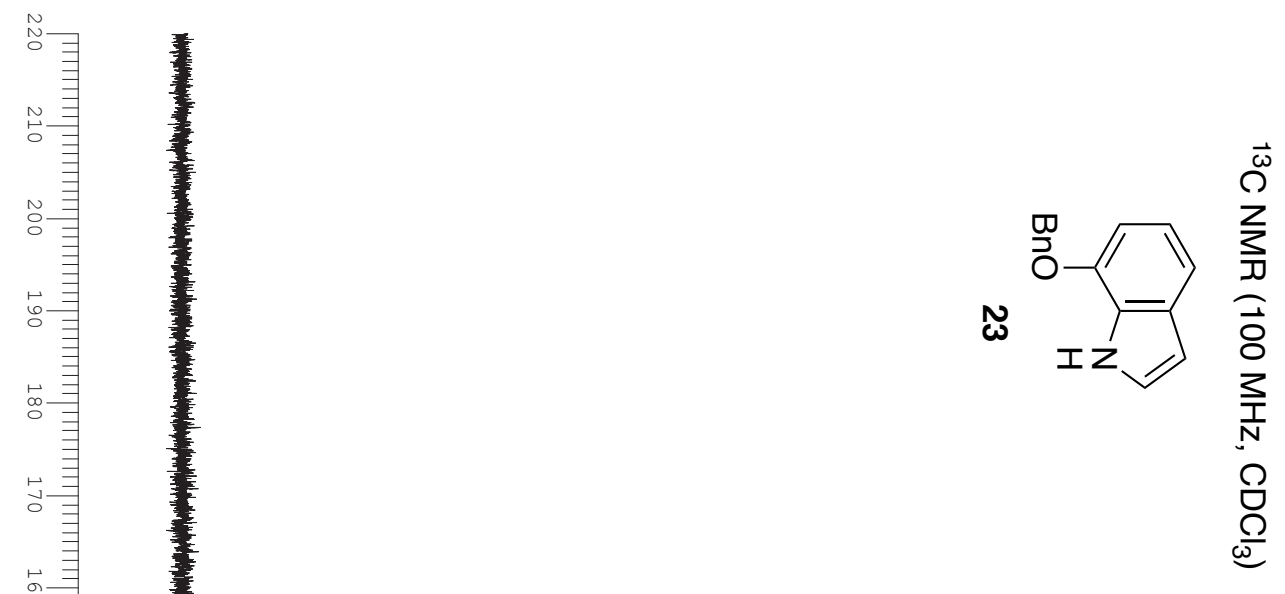

145.356

137.066 129.261 128.578 127.820 126.528 123.663 120.057 $-113.636$ 


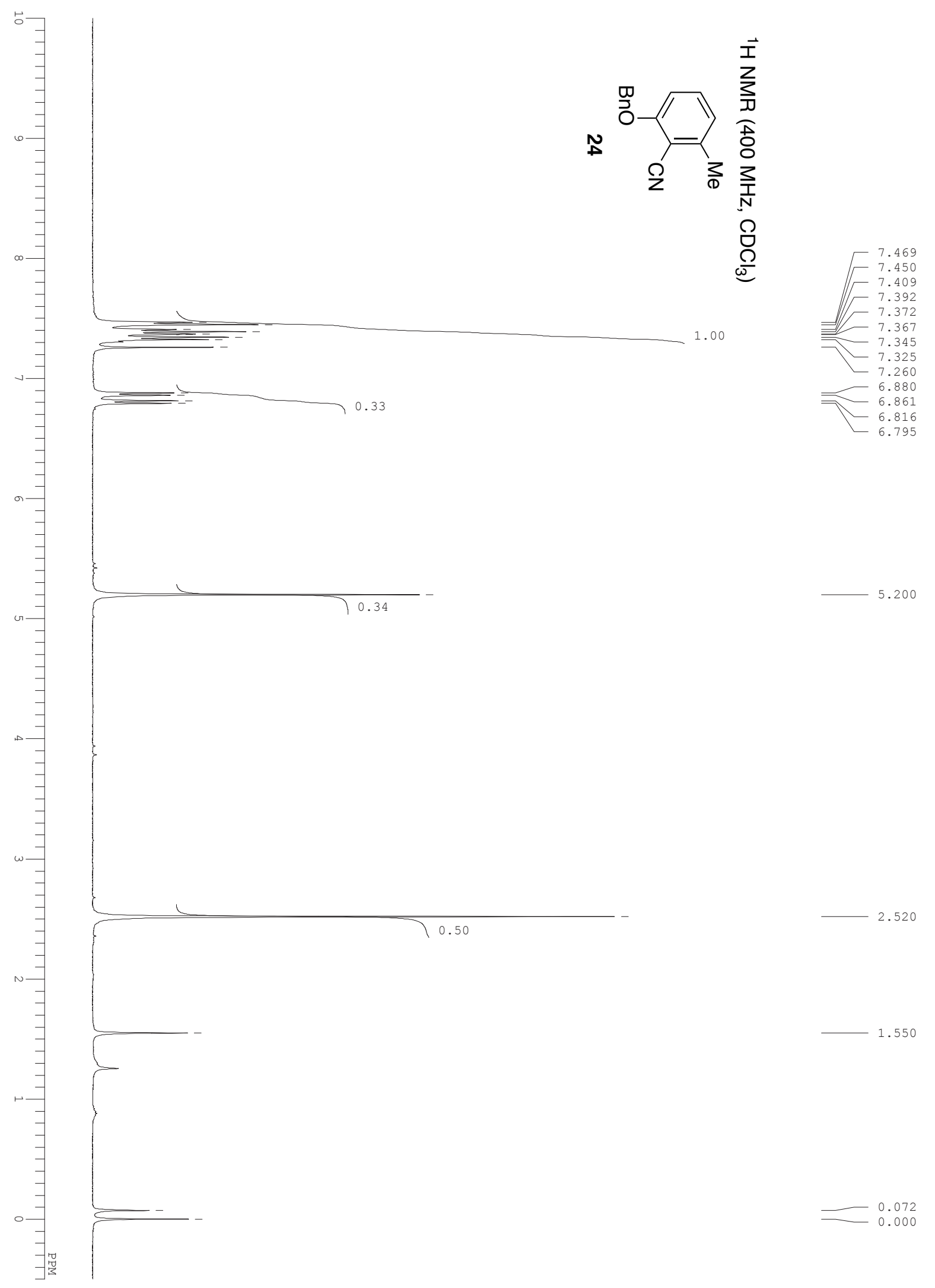




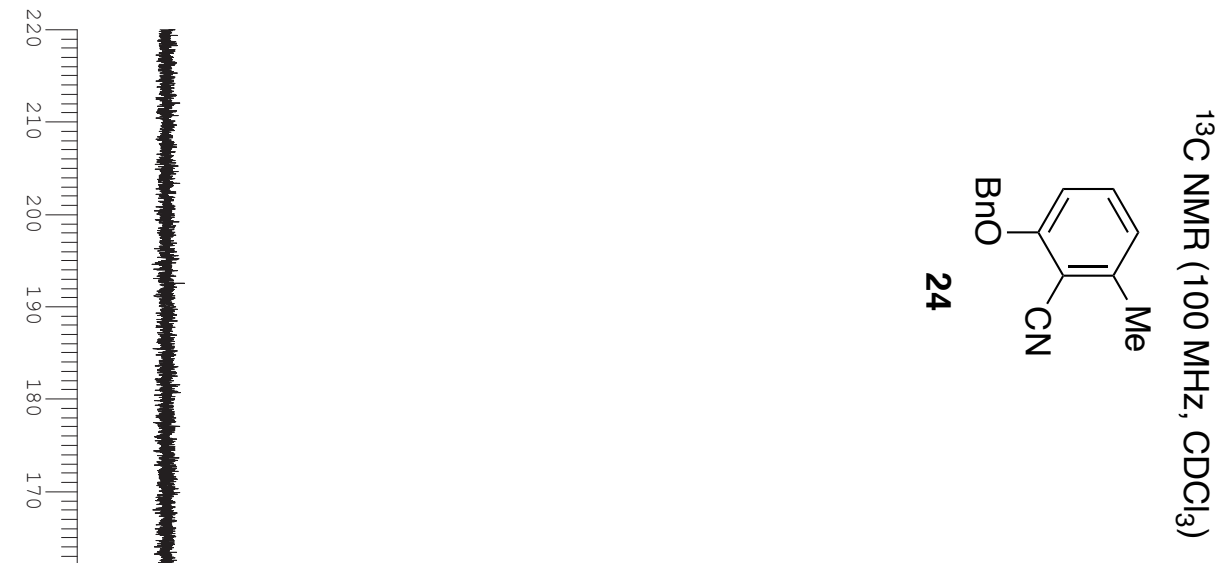

160.611

144.006

135.847 133.361 128.685

128.100

126.890

占

115.595

$\stackrel{⿱ ⺊ 尸}{\circ}$

109.774

103.024

。”

君

害

77.313

77.000

76.679

彗

驺

은

类

응

20.532

慧 


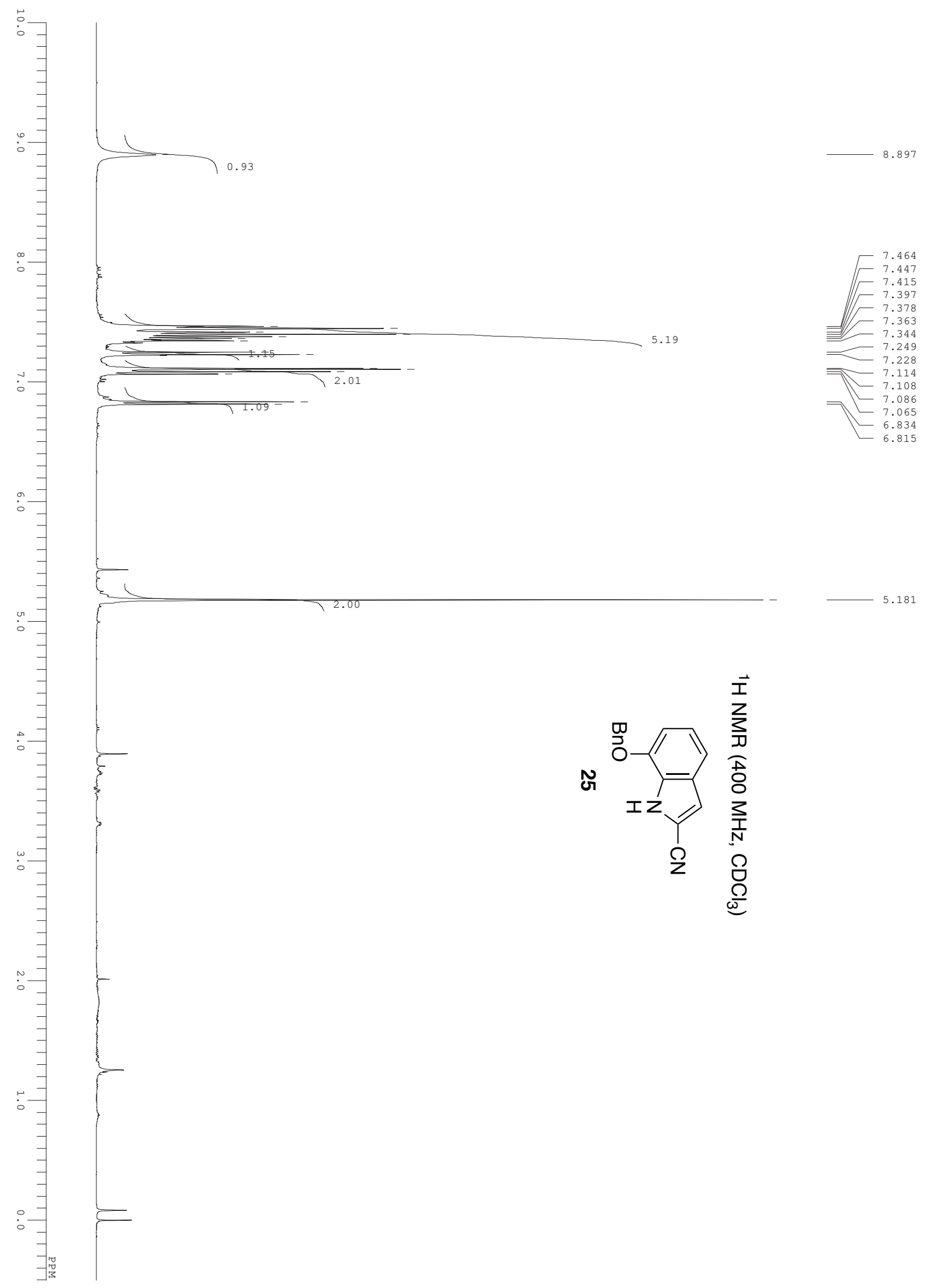



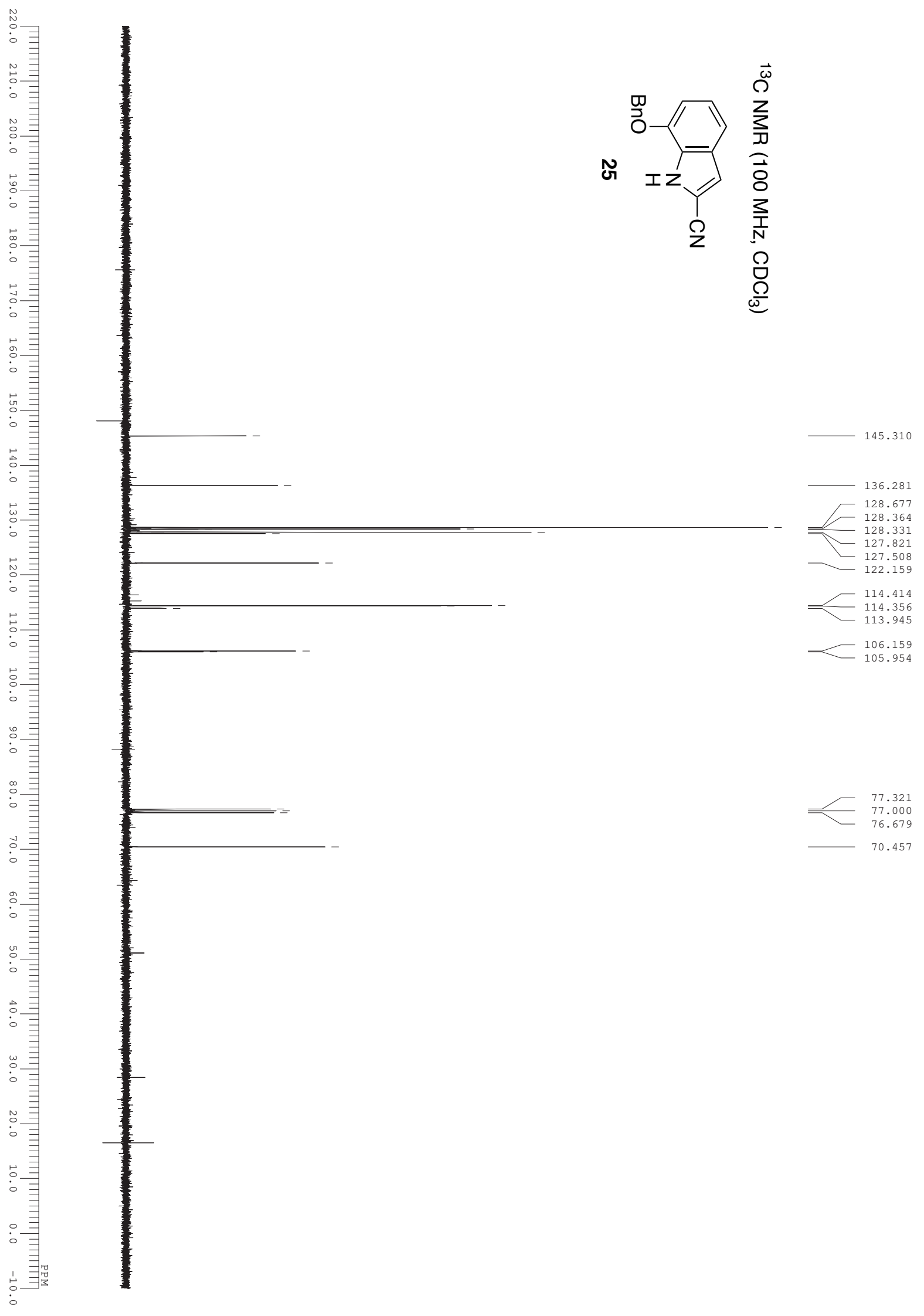

S36 

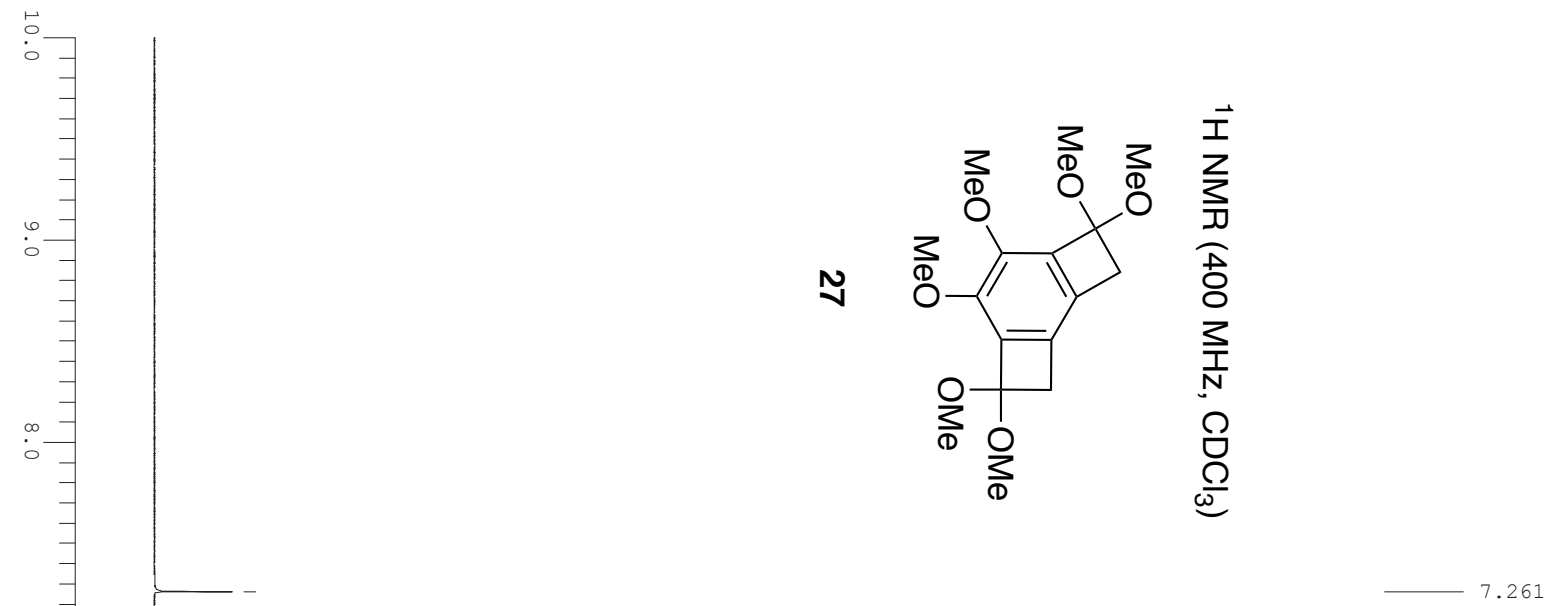

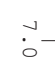

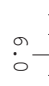

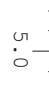

$:$

6.00

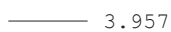

.

$\stackrel{\omega}{\circ}$

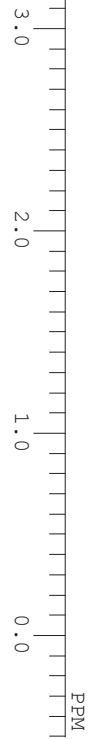

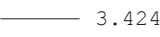

3.94
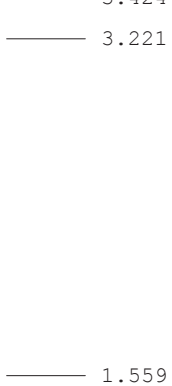


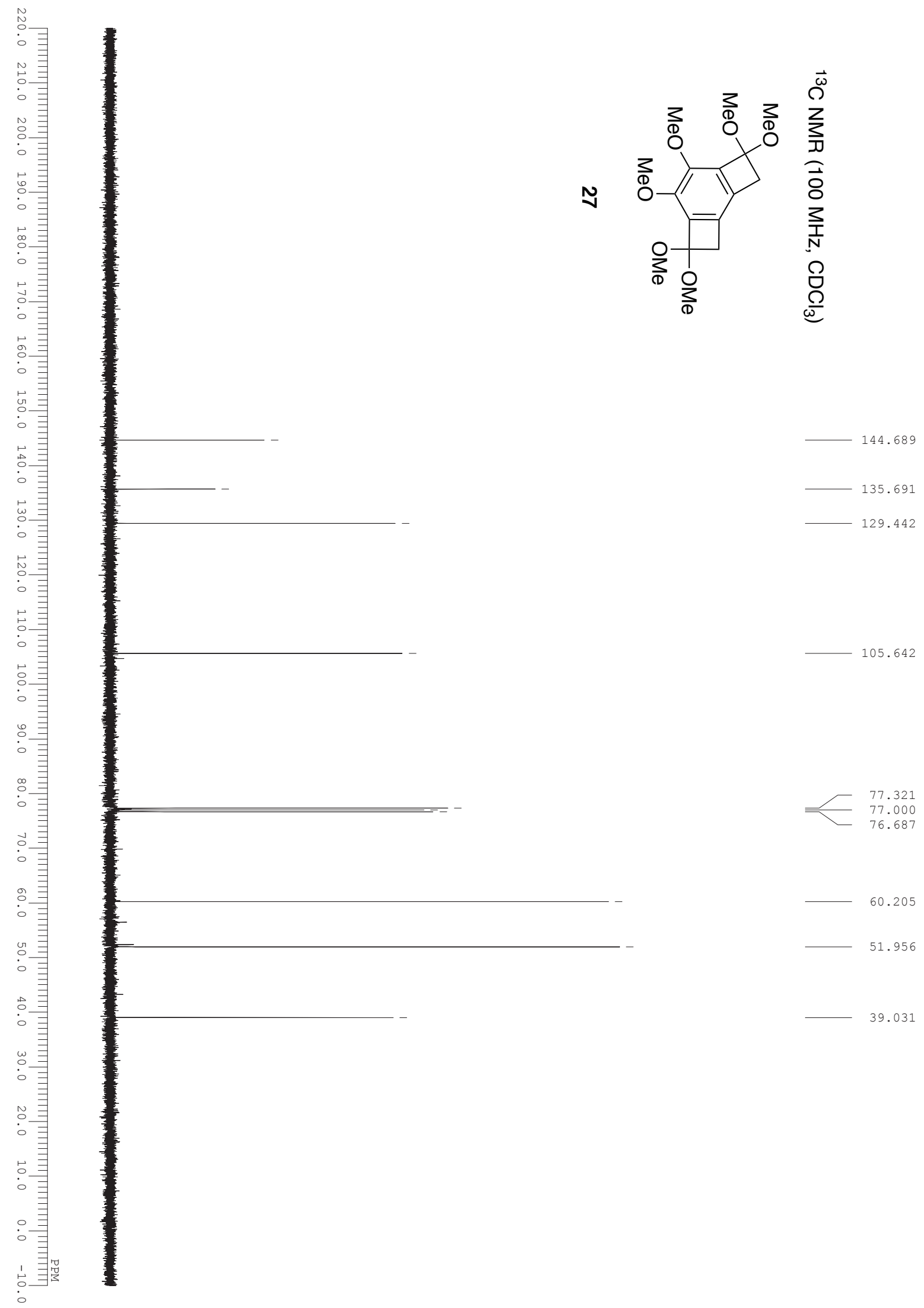




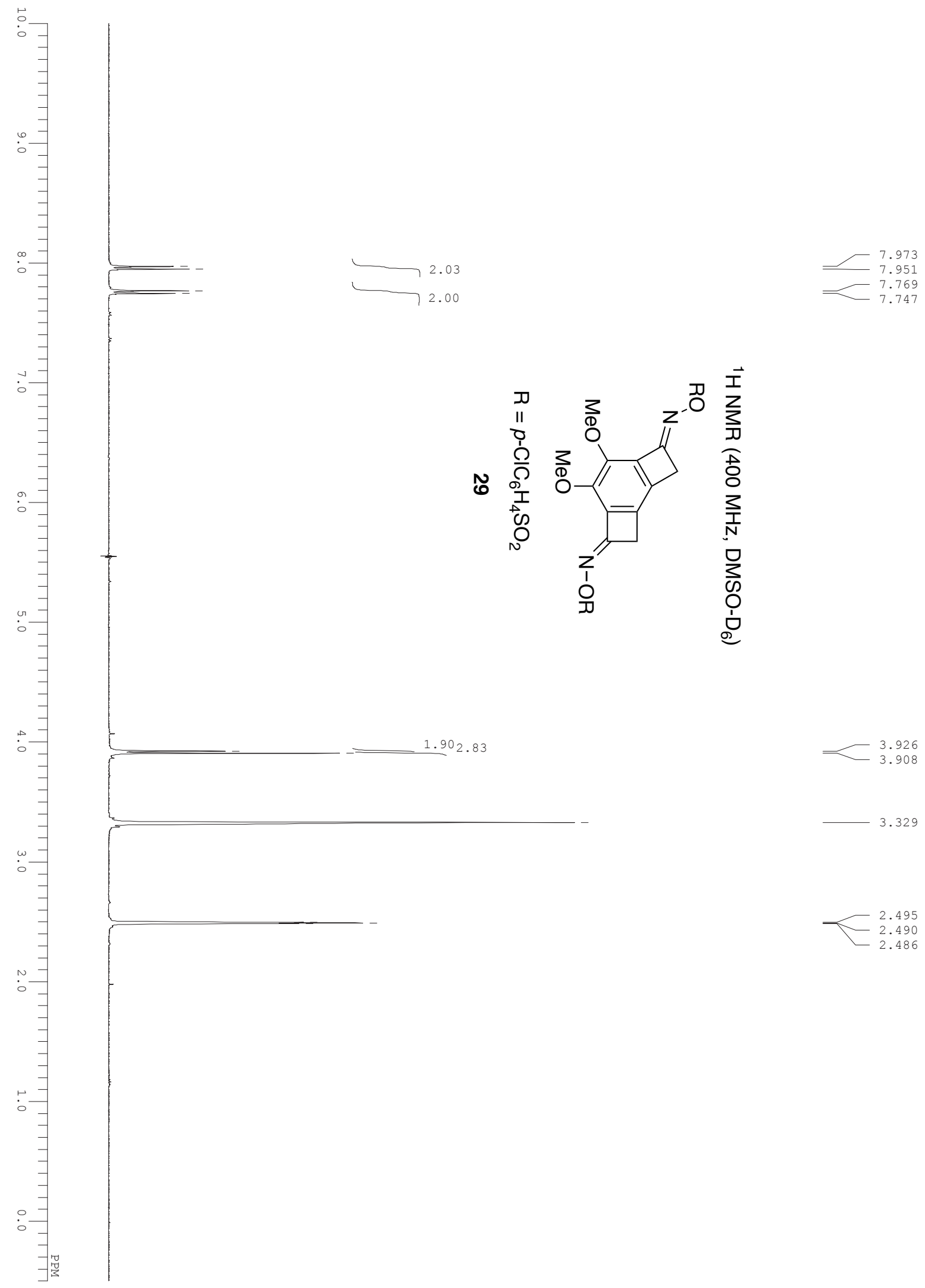




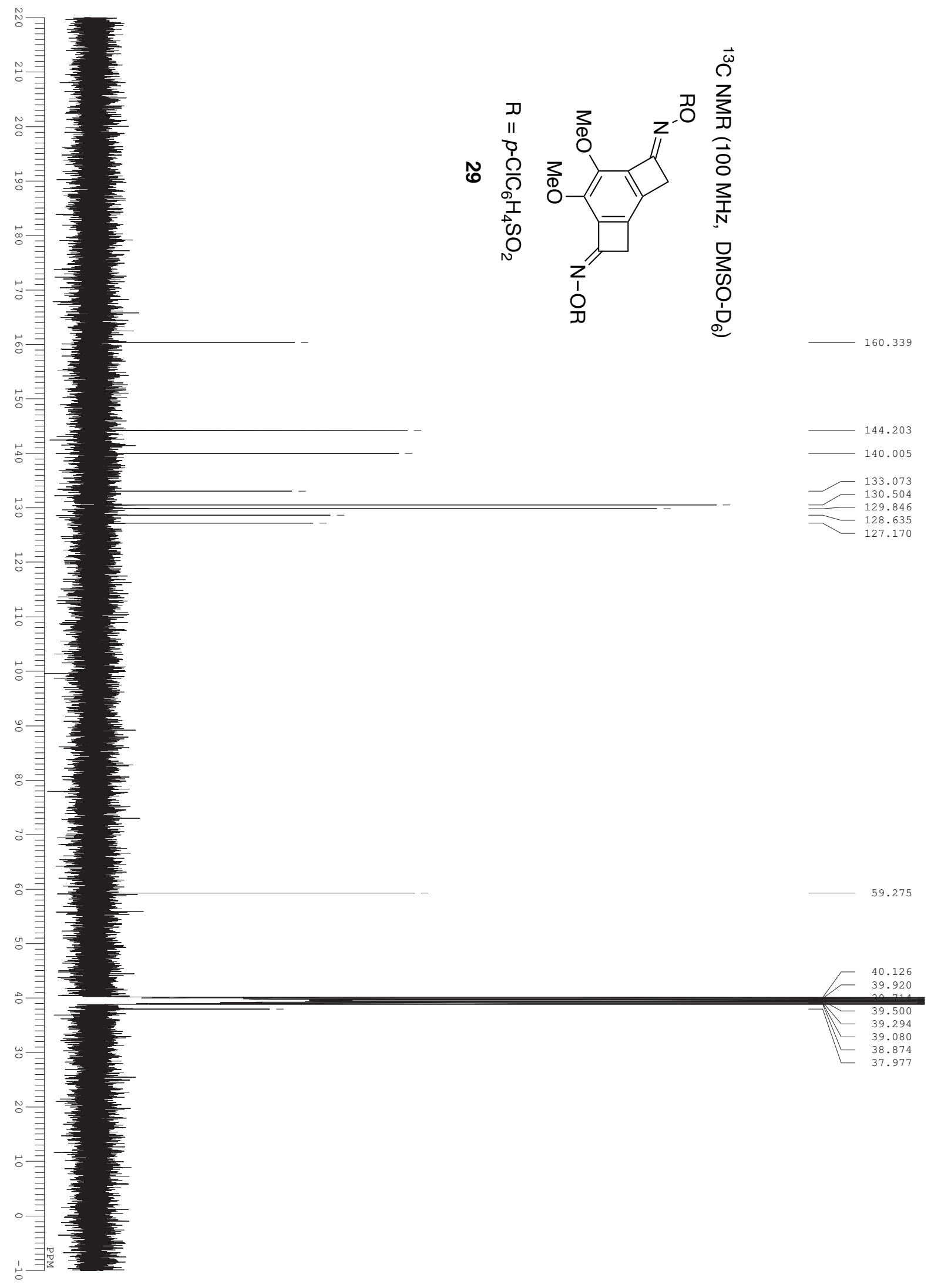




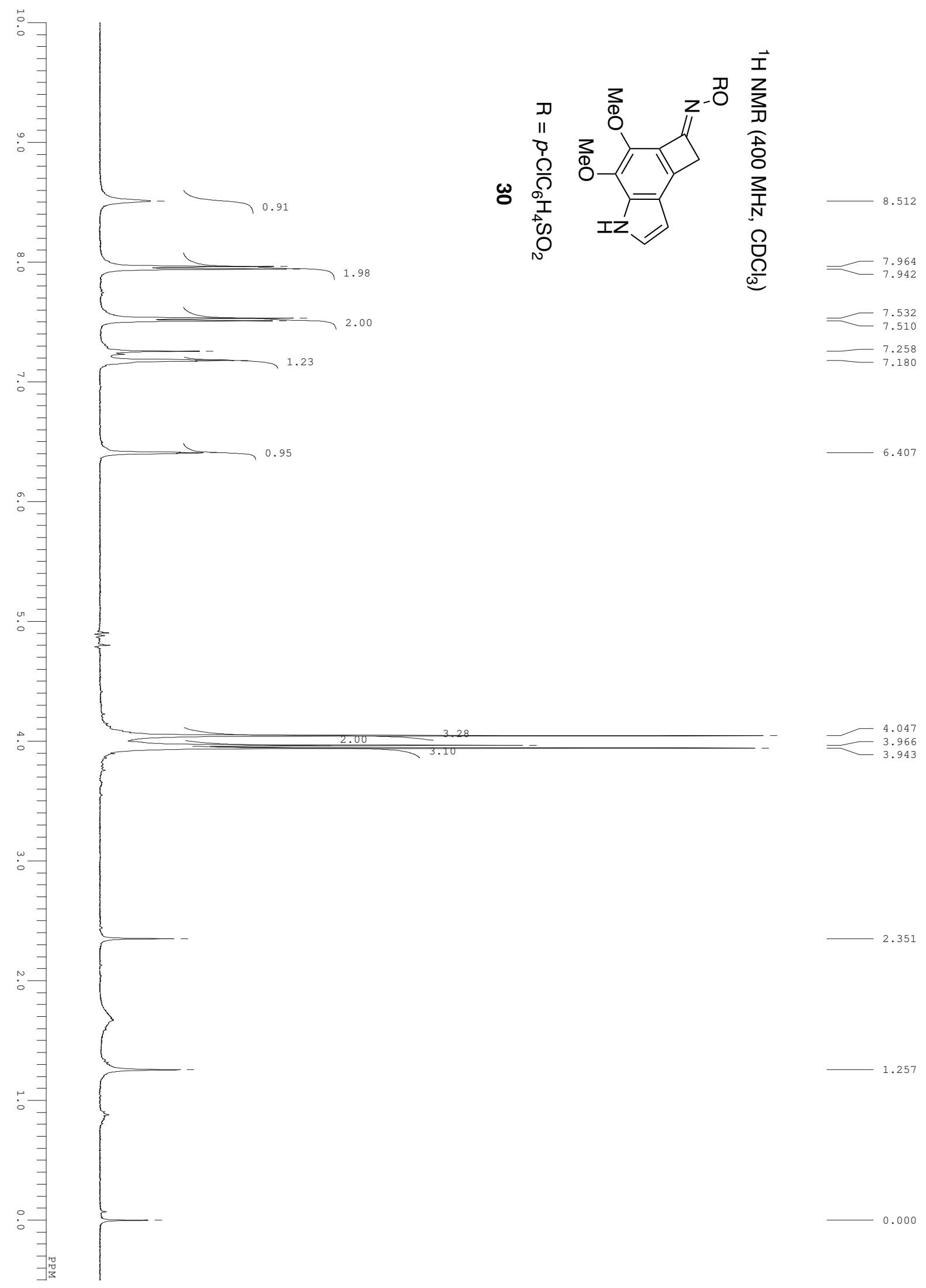




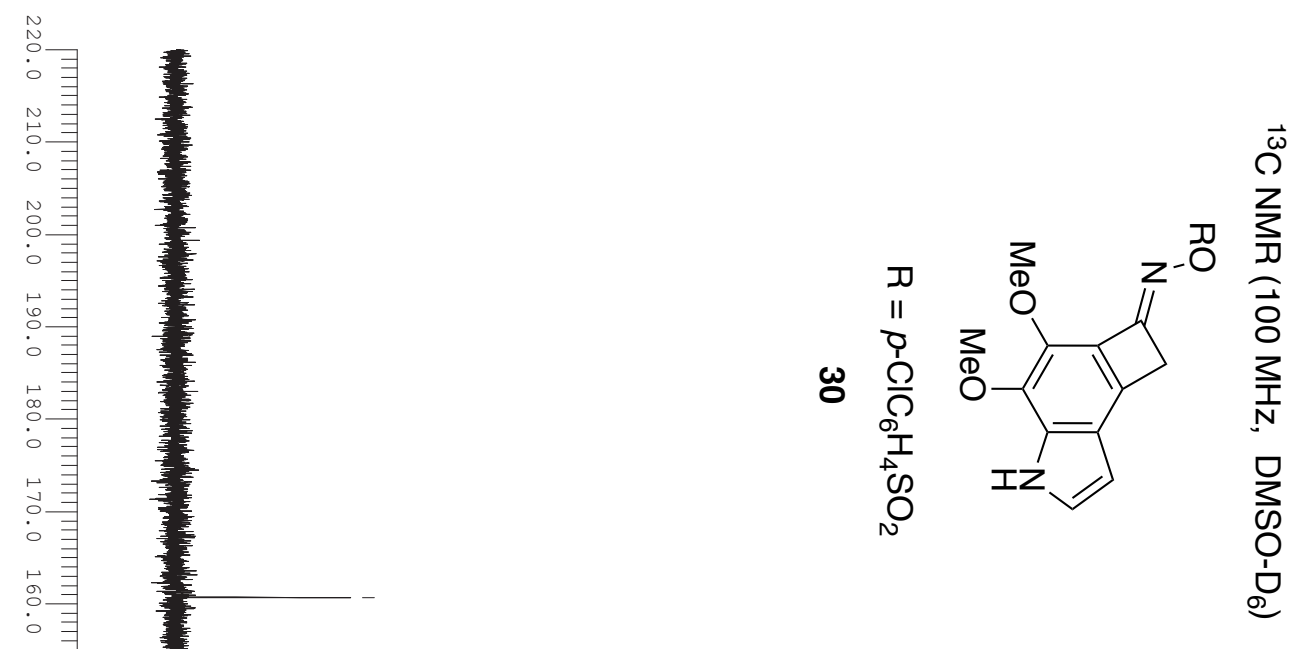

160.718

100.282

40.326
39.642

135.658

135.287

133.666

130.438

129.714

116.072

品录

$\stackrel{\bullet}{\circ}$$$
\text { (1) }
$$$$
\text { : }
$$

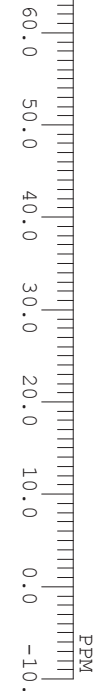

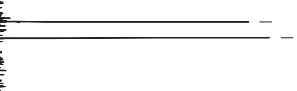

59.077

40.126

39.912

39.706

39.500

39.286
39.080

38.874

37.812 


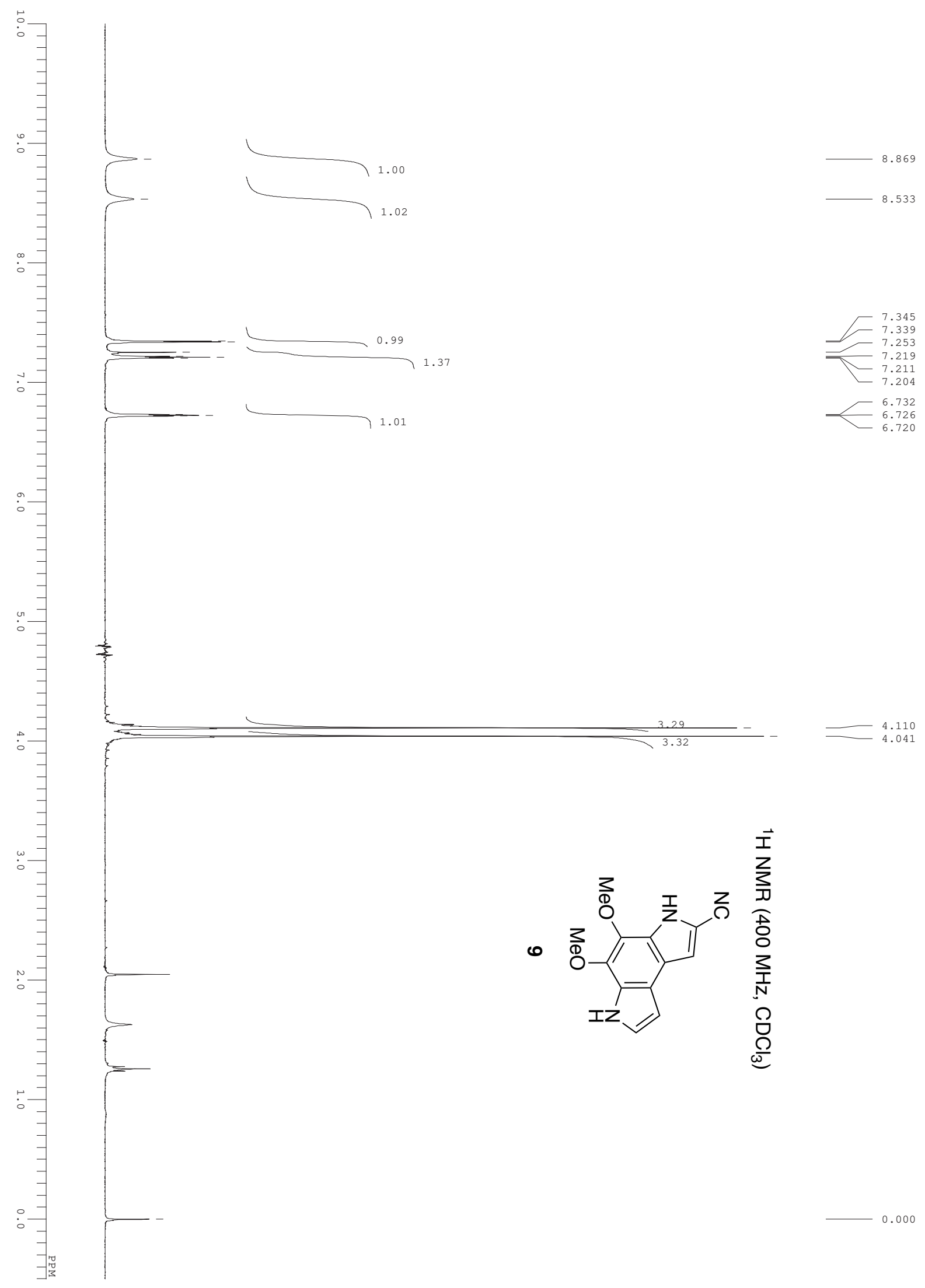




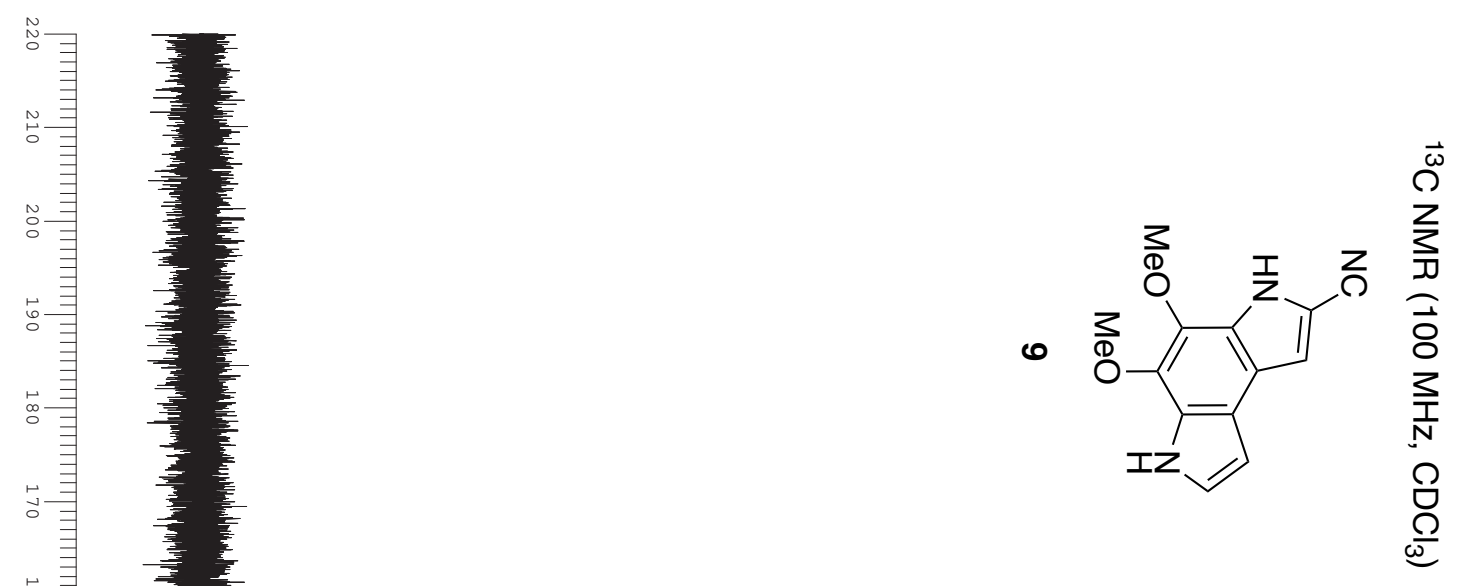

137.823 133.098 128.323 125.746 122.691 116.525 114.986
113.216 103.452
101.945 


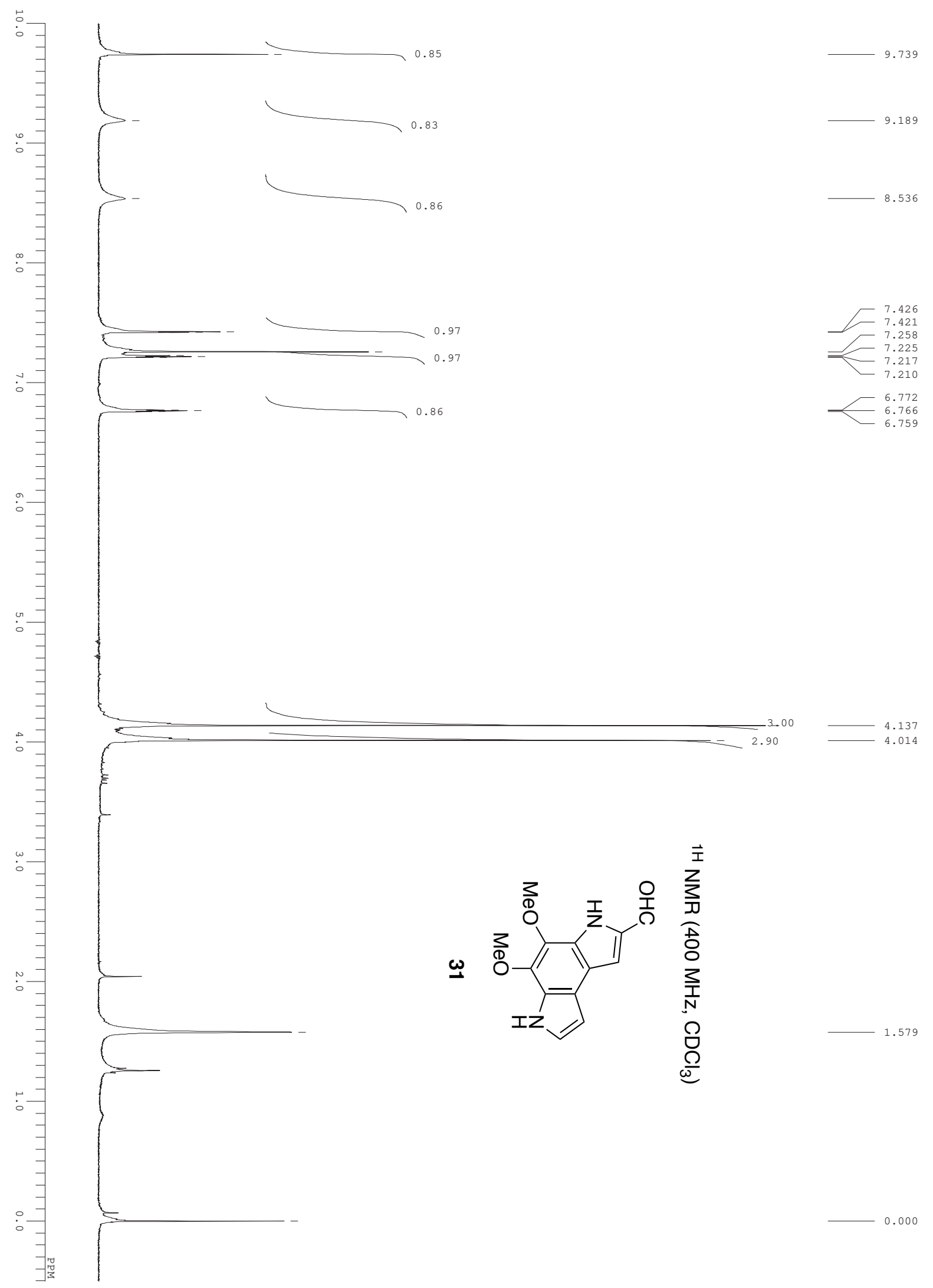




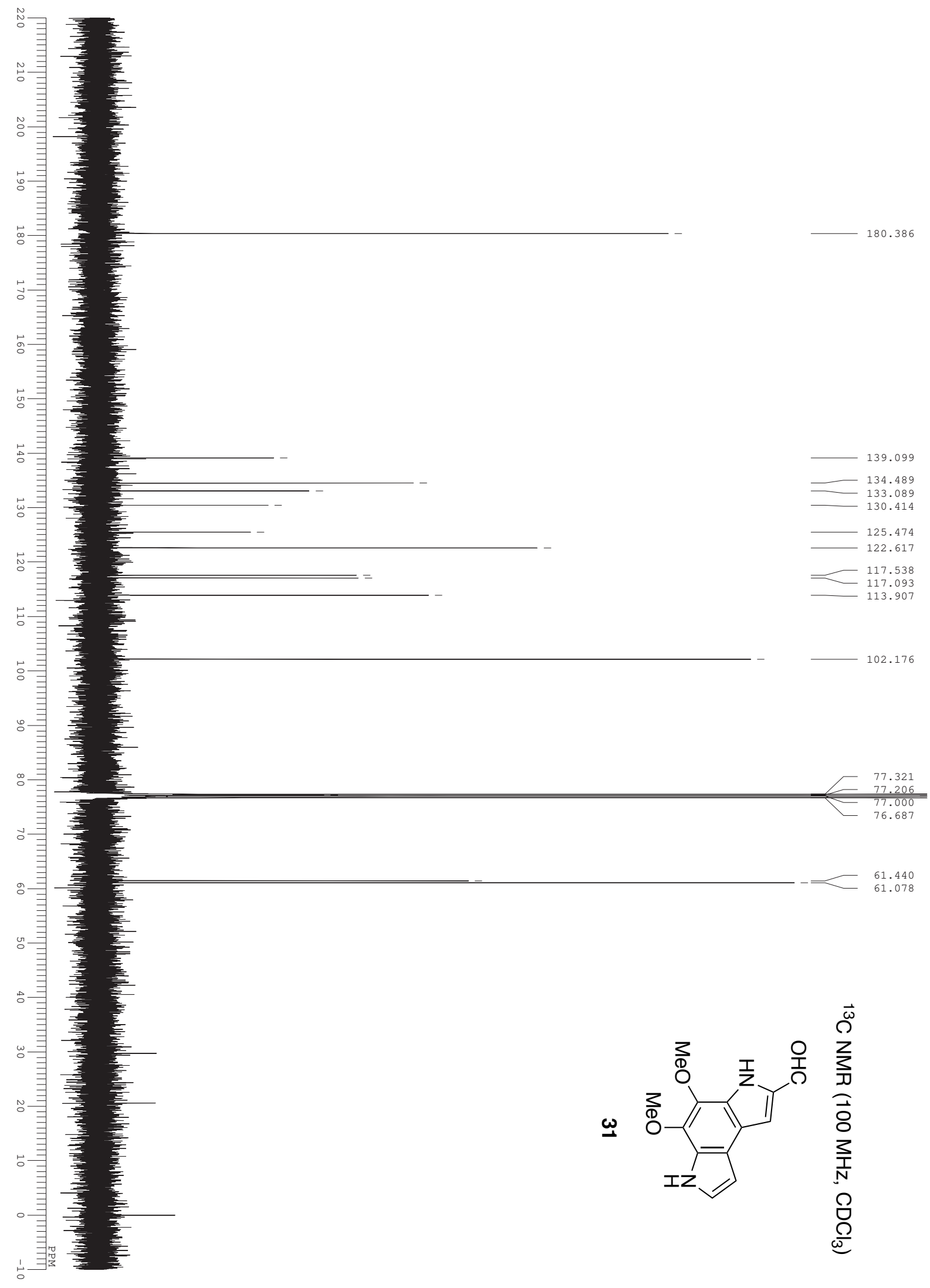



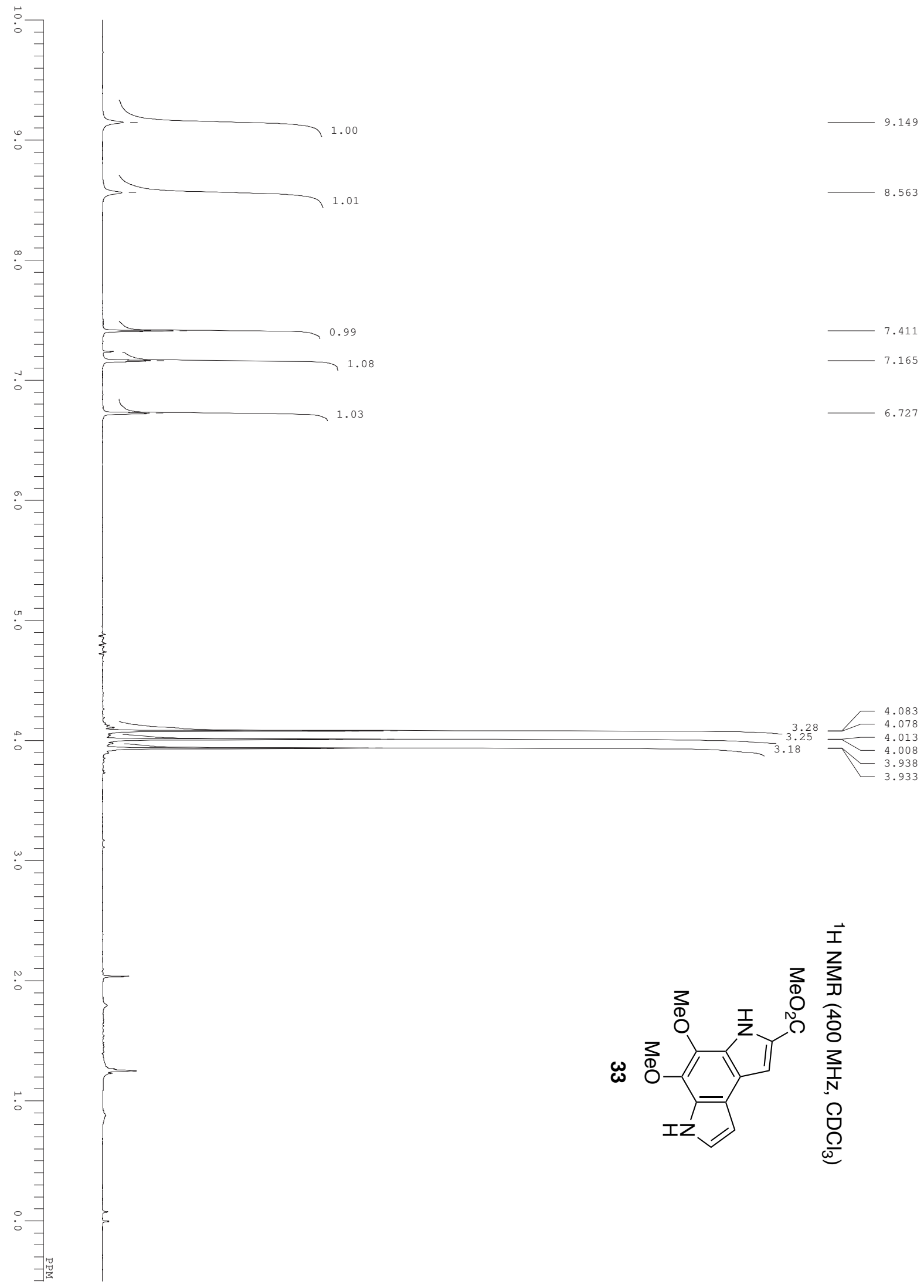

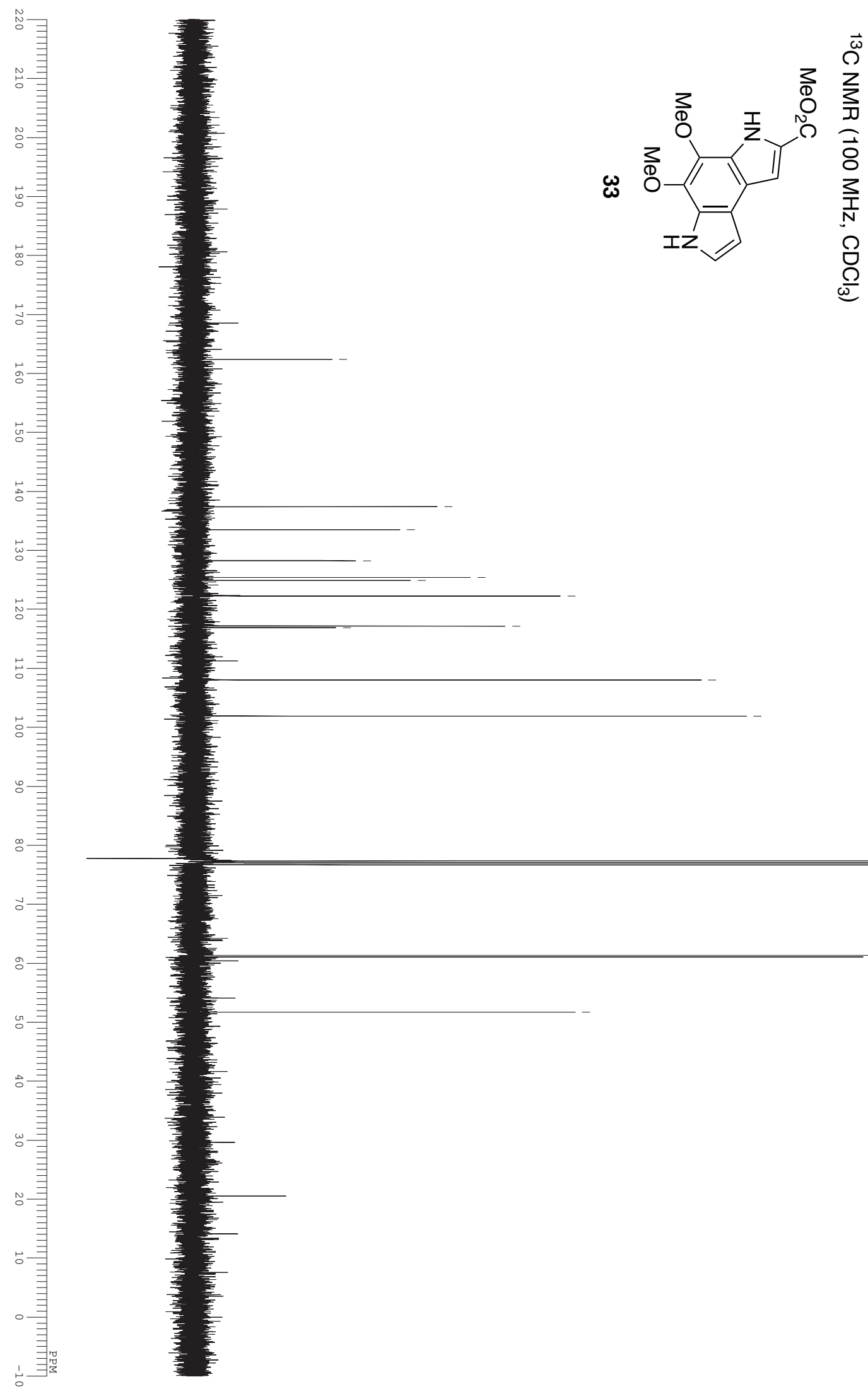

162.398

137.387

133.476

128.257

125.417

122.272

117.184
116.871

108.029

101.912

77.321

77.000
76.679

61.325
61.078

51.709 


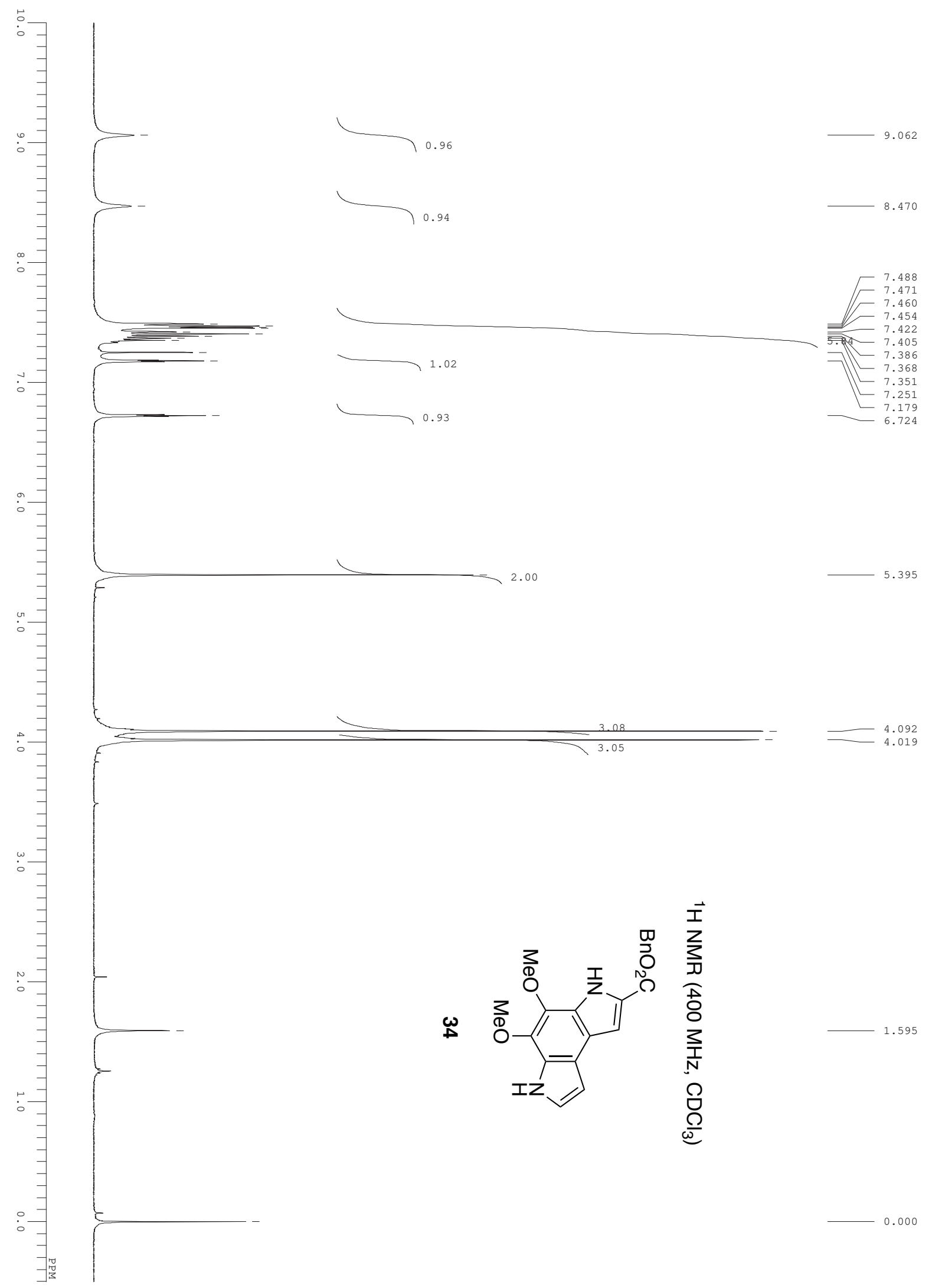




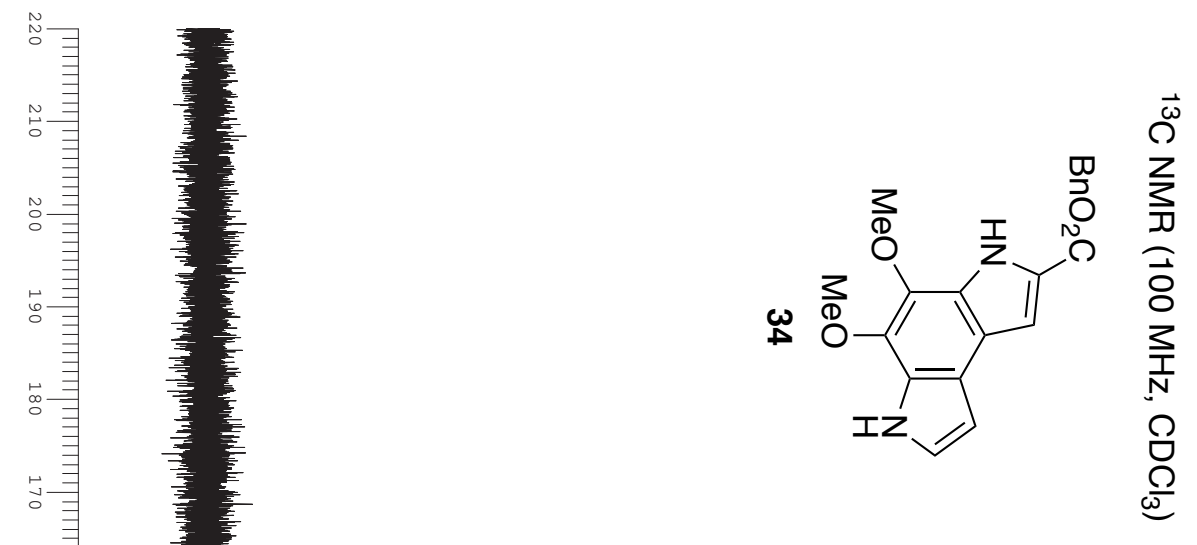

161.747

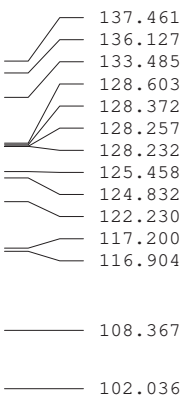




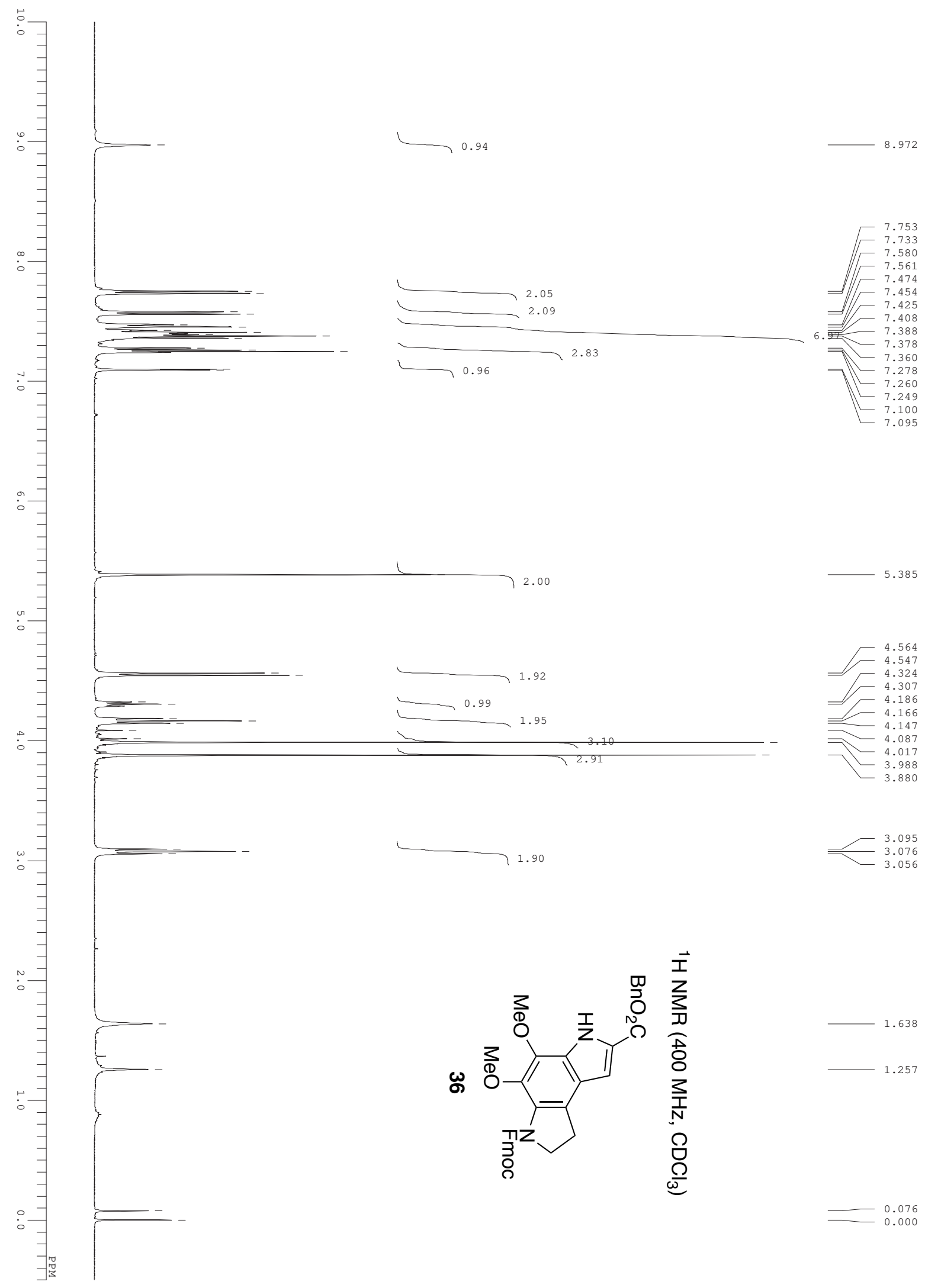




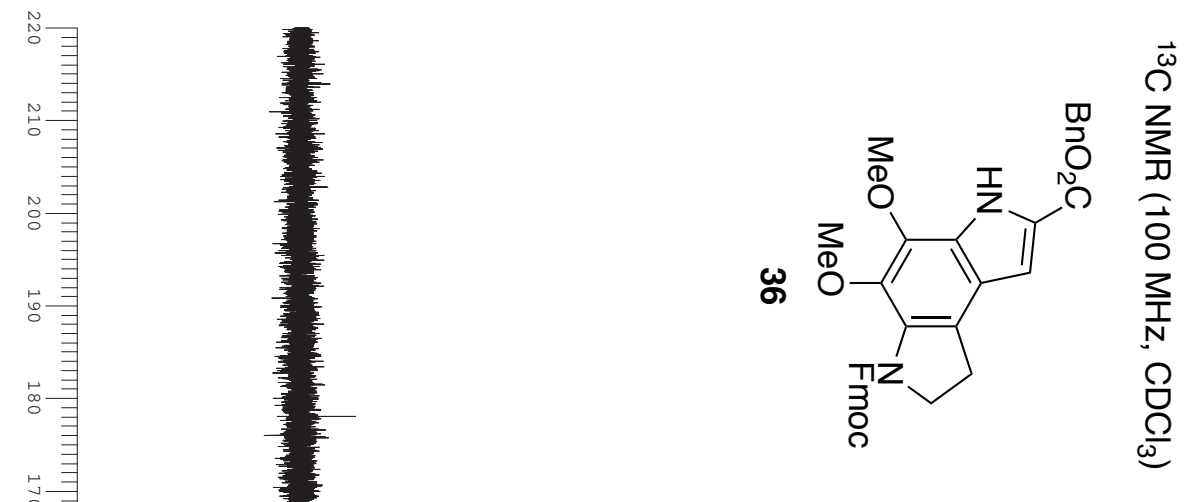

161.416

155.095

143.977
142.215

142.215
141.327

137.574

135.705

130.940

130.092

128.652

128.430

128.356

127.656

127.632

127.014

121.805

120.488

119.912

107.353

77.321

77.000
76.679

67.601

66.679

61.132
60.326

51.750

47.355

28.640 


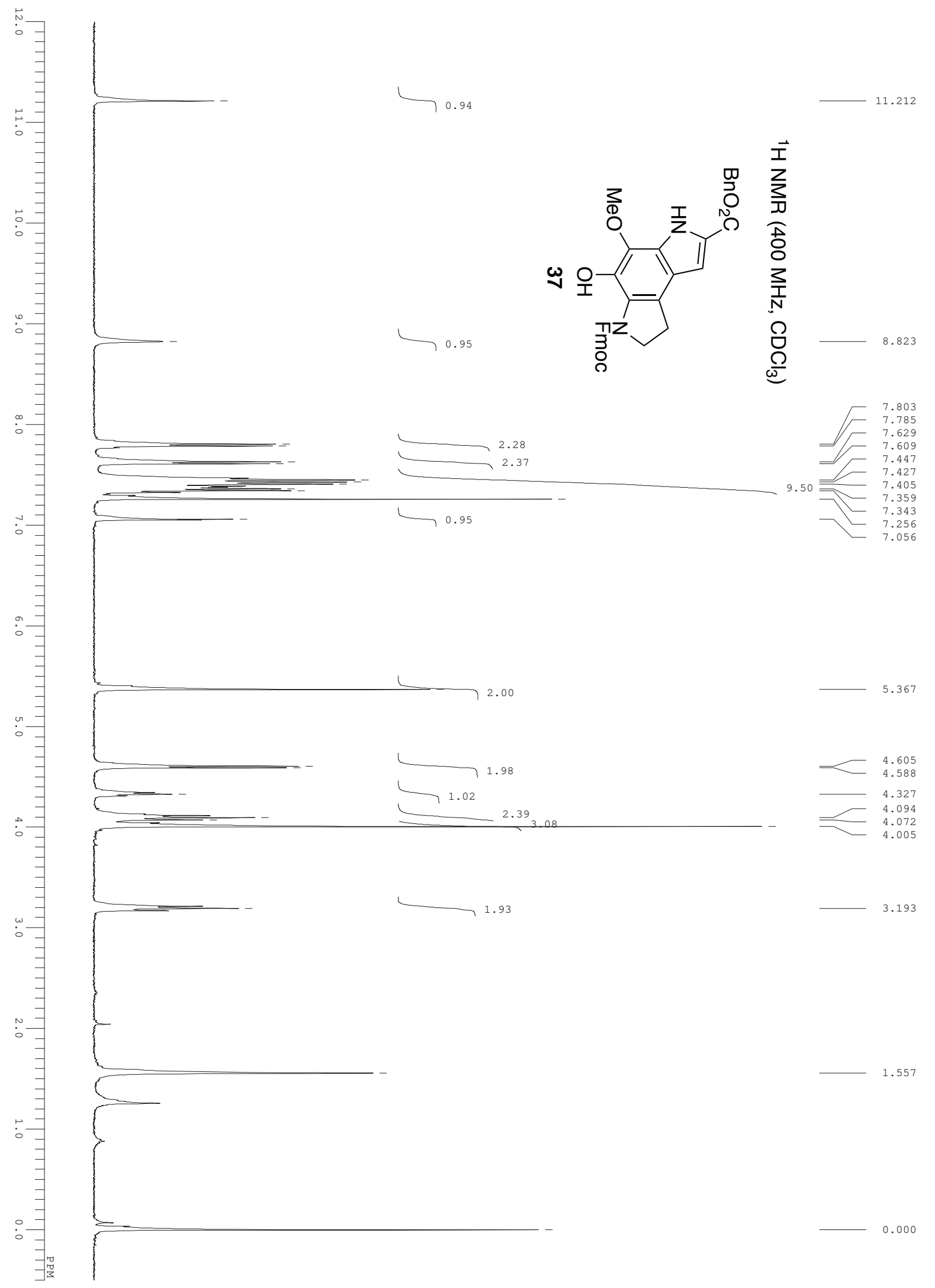




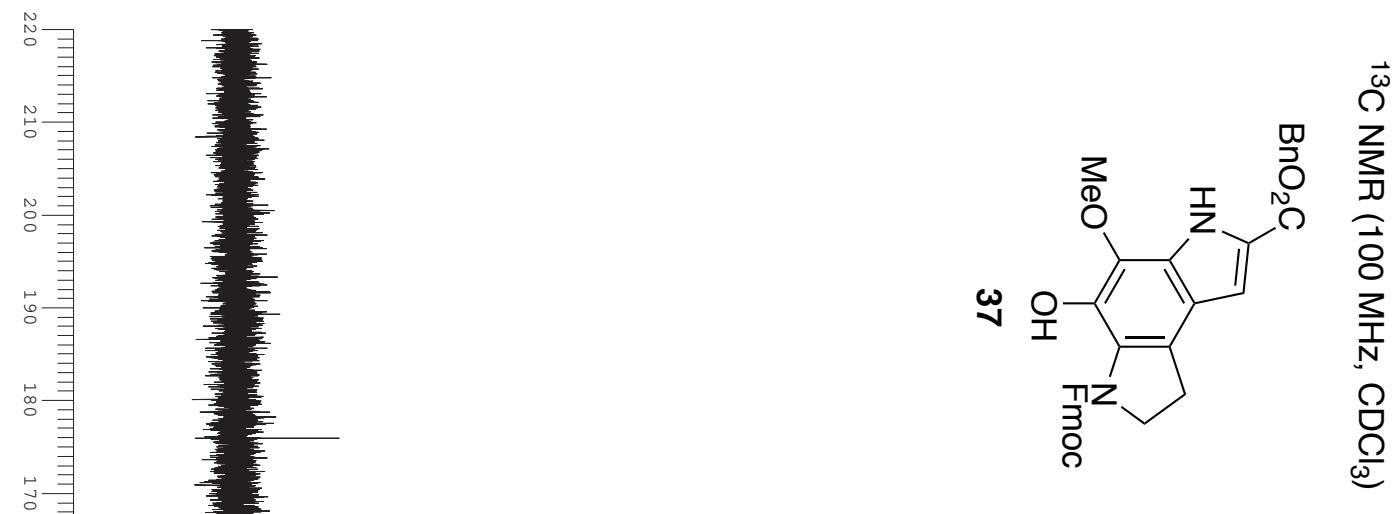

77.321
77.000

77.000
76.679

68.762
66.507

60.680

49.306
47.034

26.722 


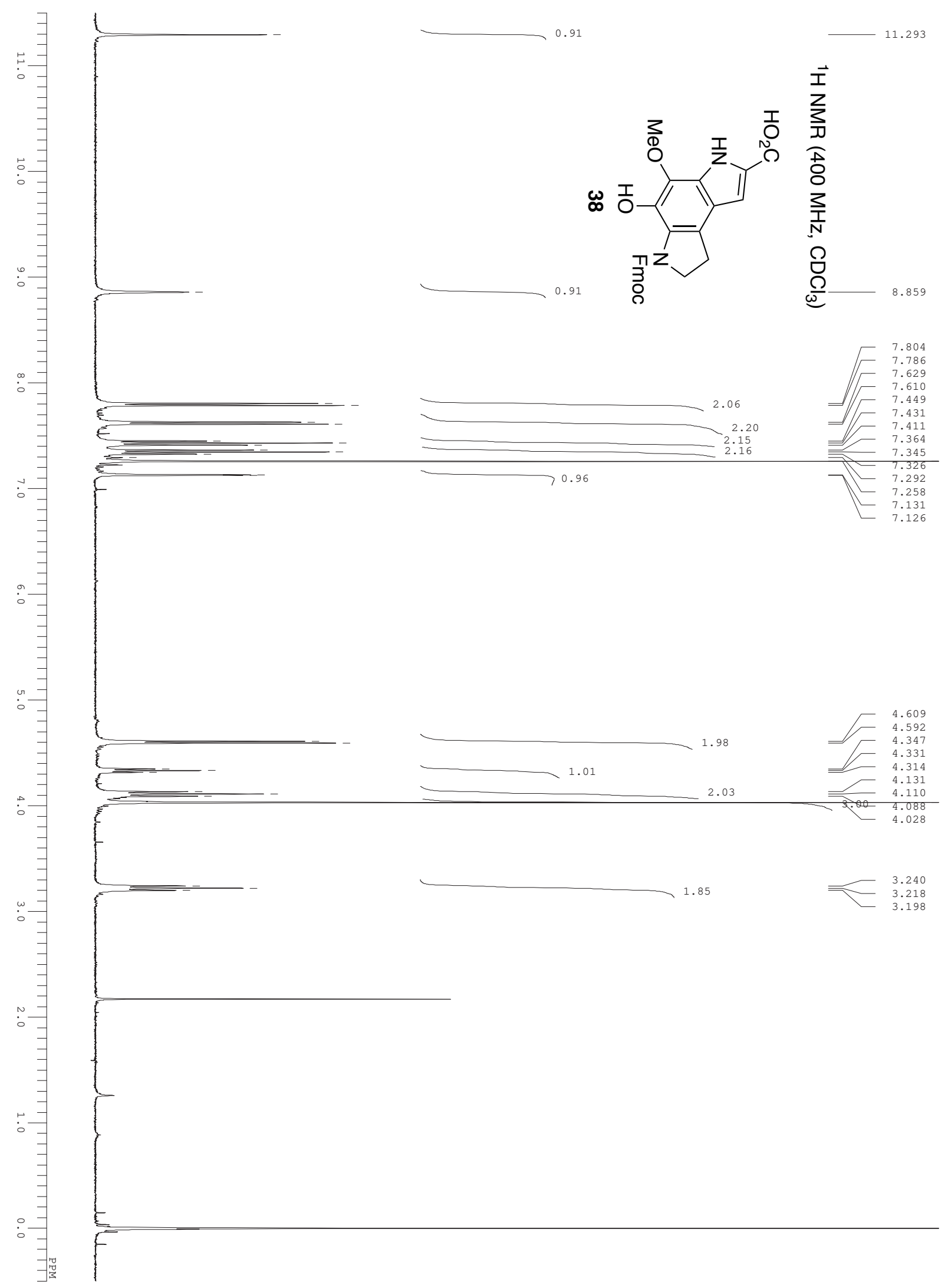




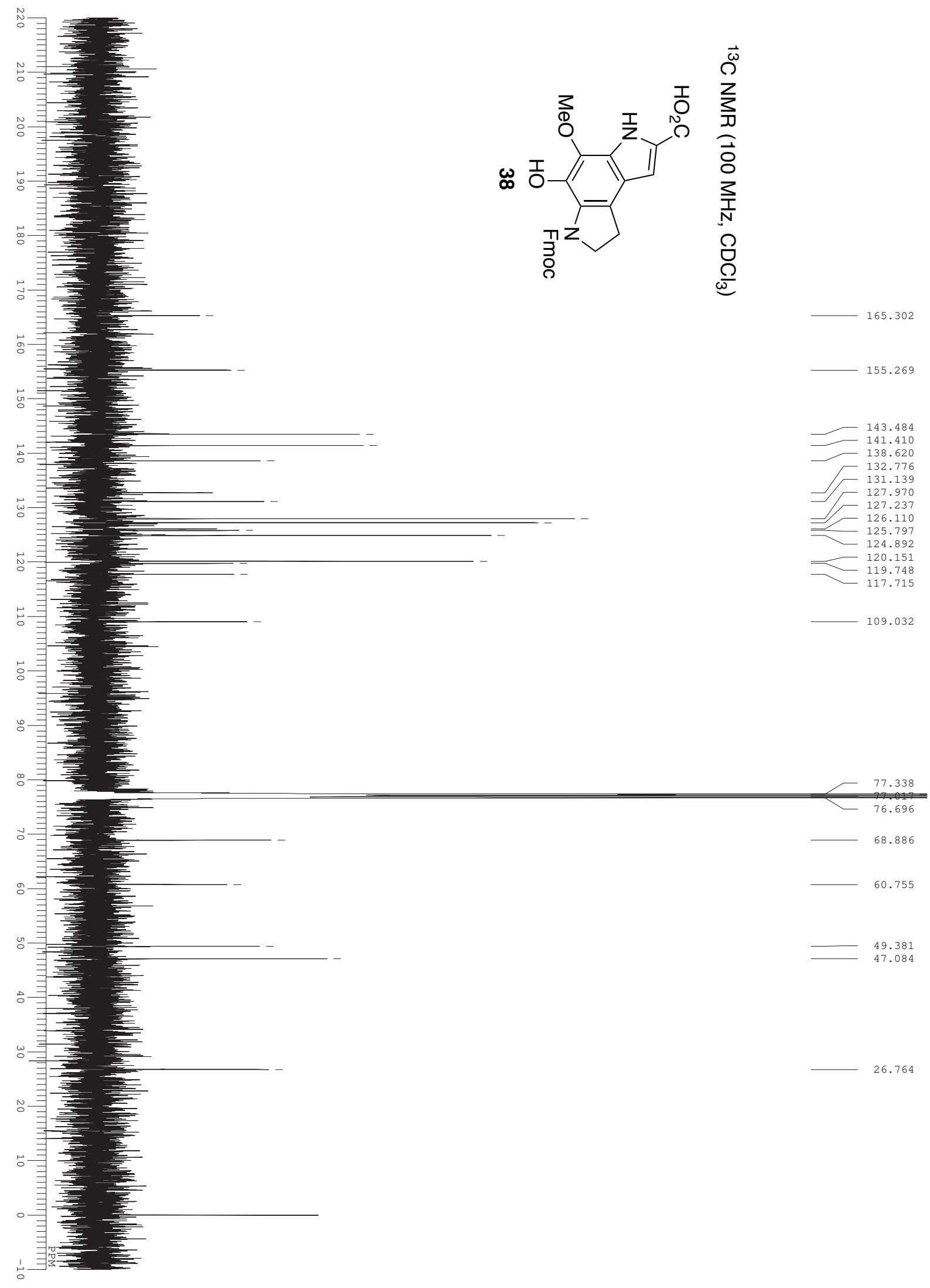




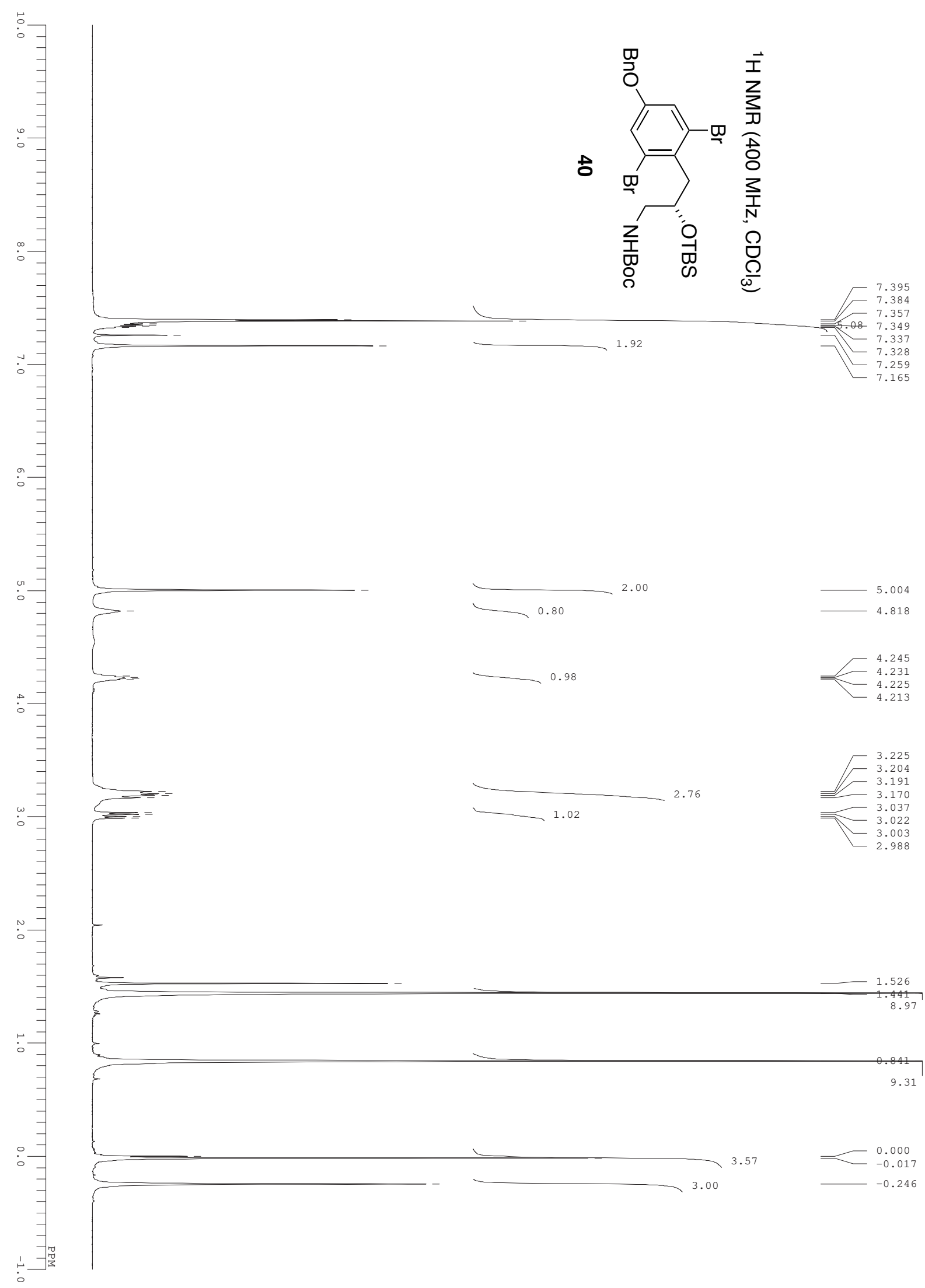




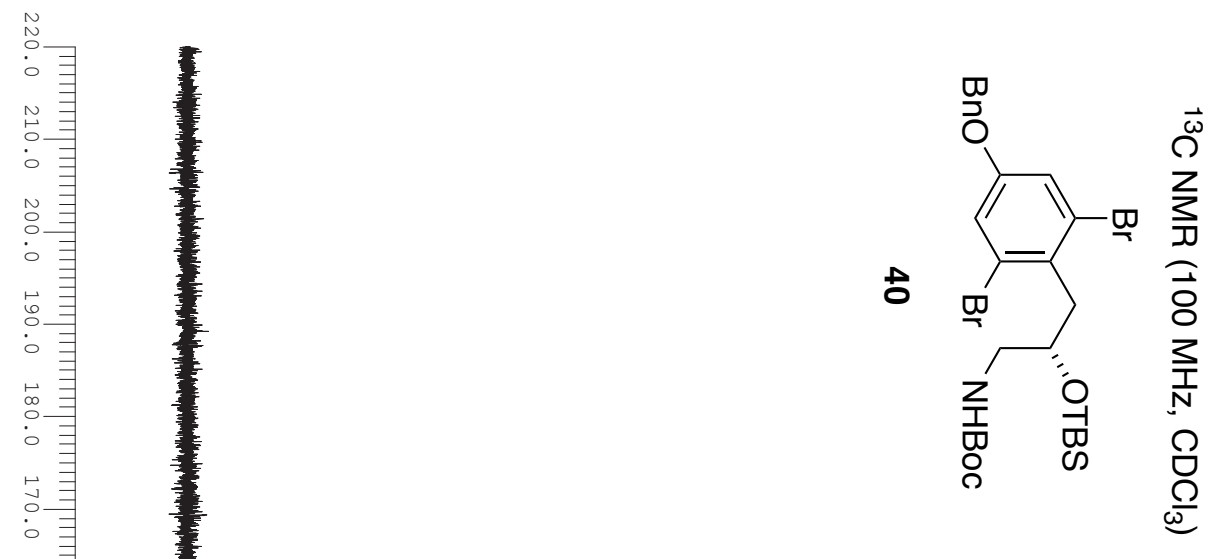

157.598 155.968

을

品录

品录

存

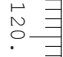

芦录

。当

空

$\stackrel{\circ}{\circ}$

$\stackrel{\infty}{\circ=1}$

罪

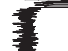

79.083

77.321 77.198 76.679 70.463 70.019

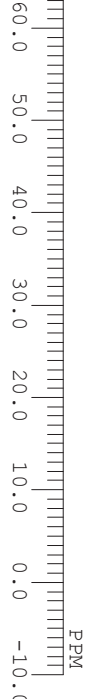

45.979 40.595

28.427 27.398 25.817

17.856

$-4.940$ $-5.031$ 


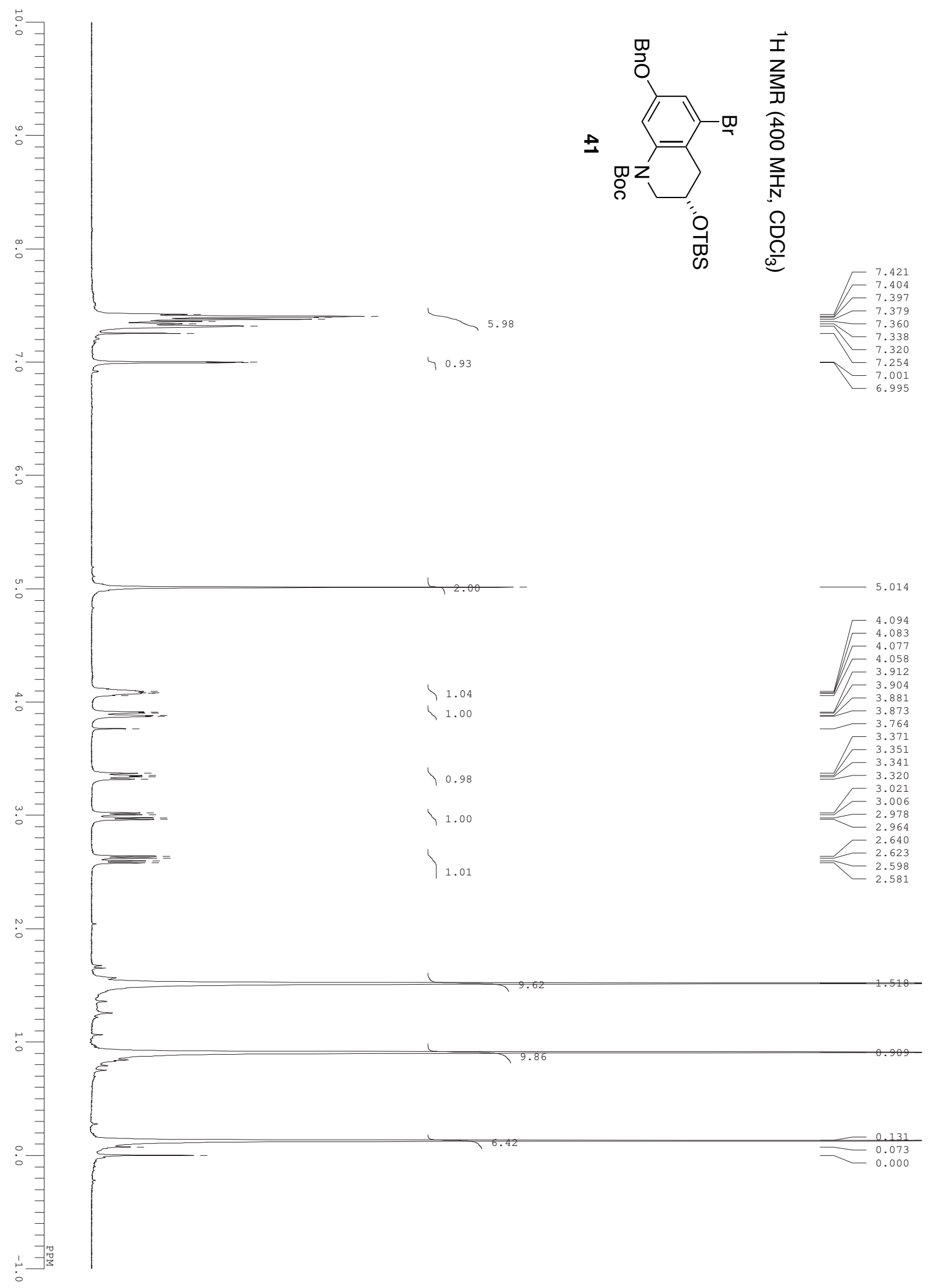




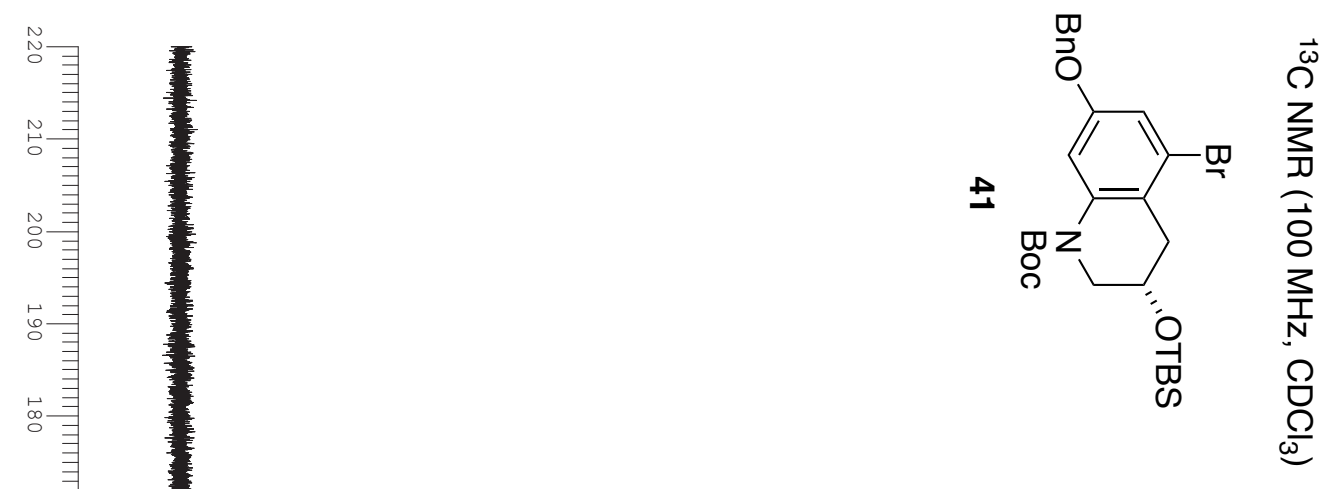

156.750 153.408

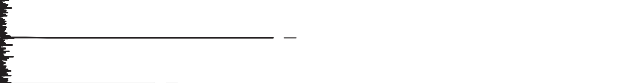

81.306 


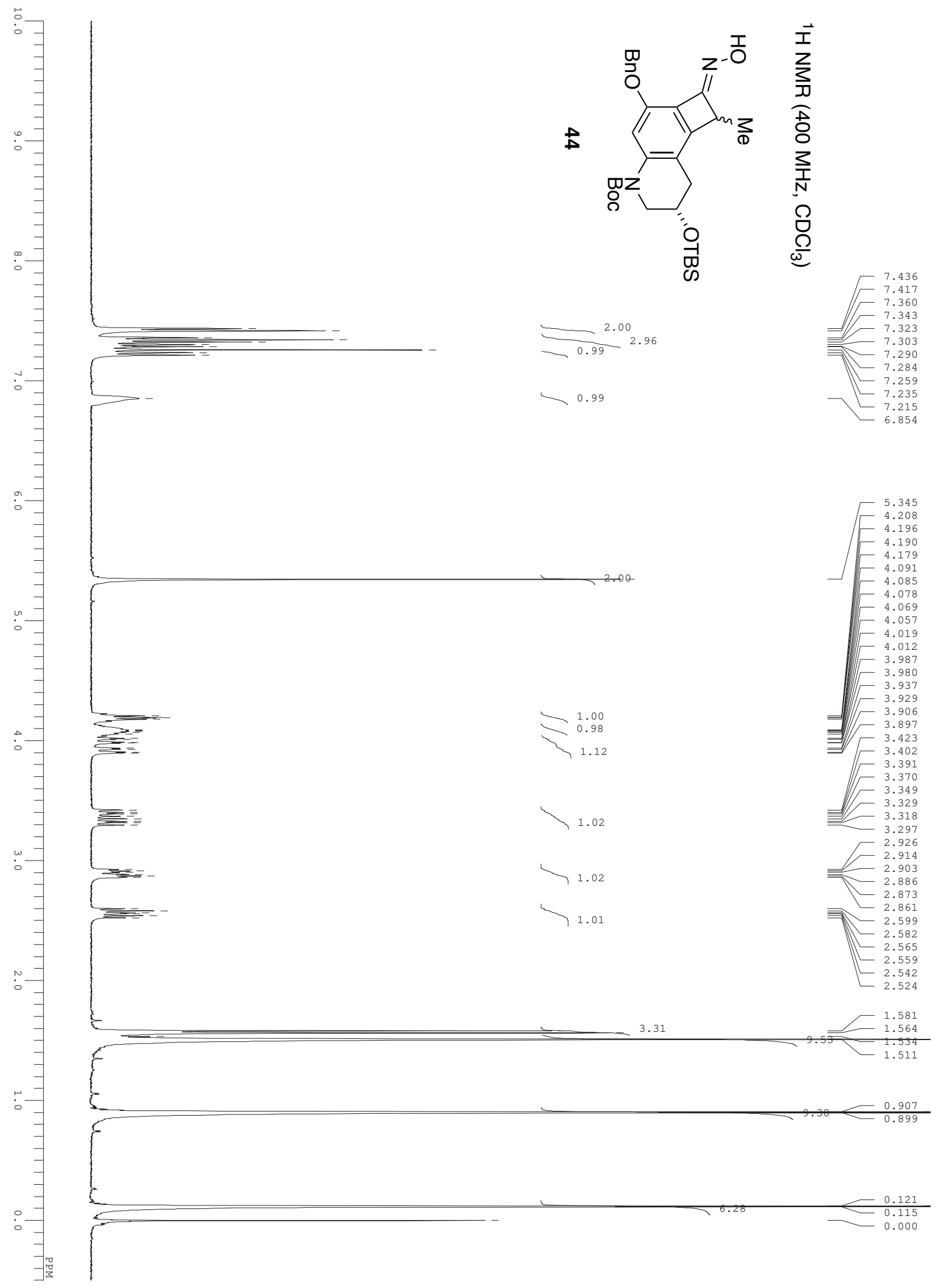




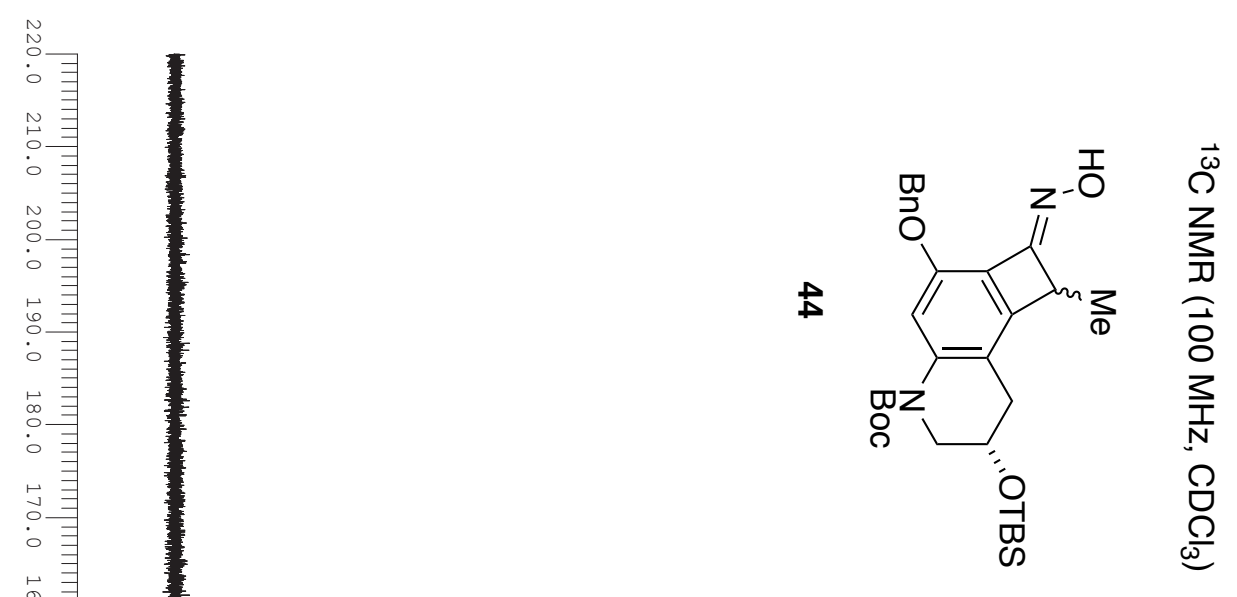

156.232

153.358

150.427

142.499

142.466

137.197

128.364

127.796

127.656

119.127

115.183

111.989

莫奉

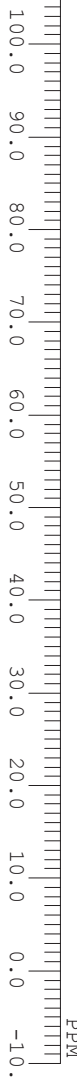

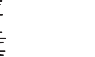

81.396

81.372

77.321

77.000

76.687

71.896

65.112

50.524

50.466

46.457

46.424

32.749

32.650

28.271

25.834

18.177
15.897

15.765

$-4.701$

$-4.726$

$-4.808$

。 


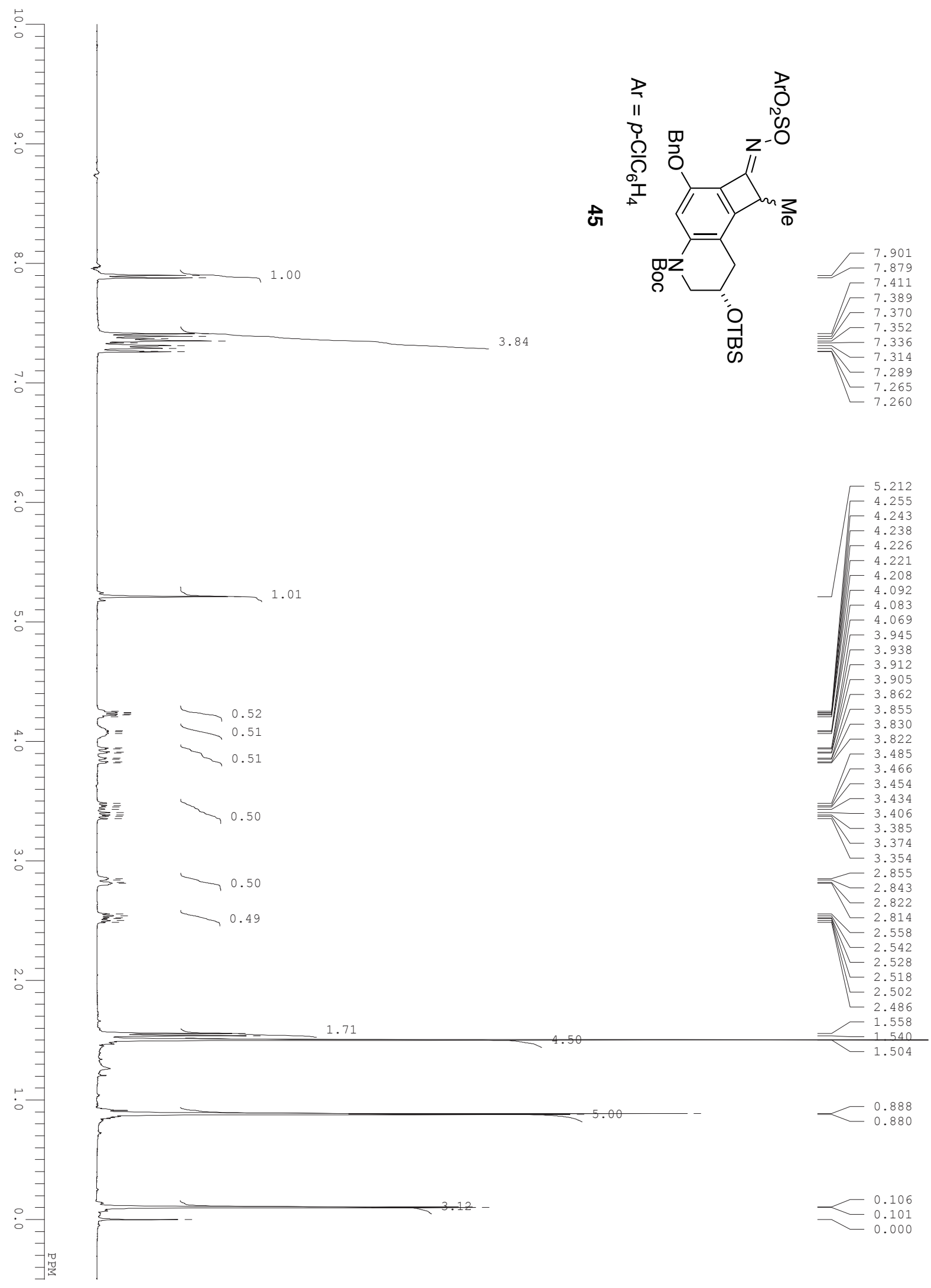




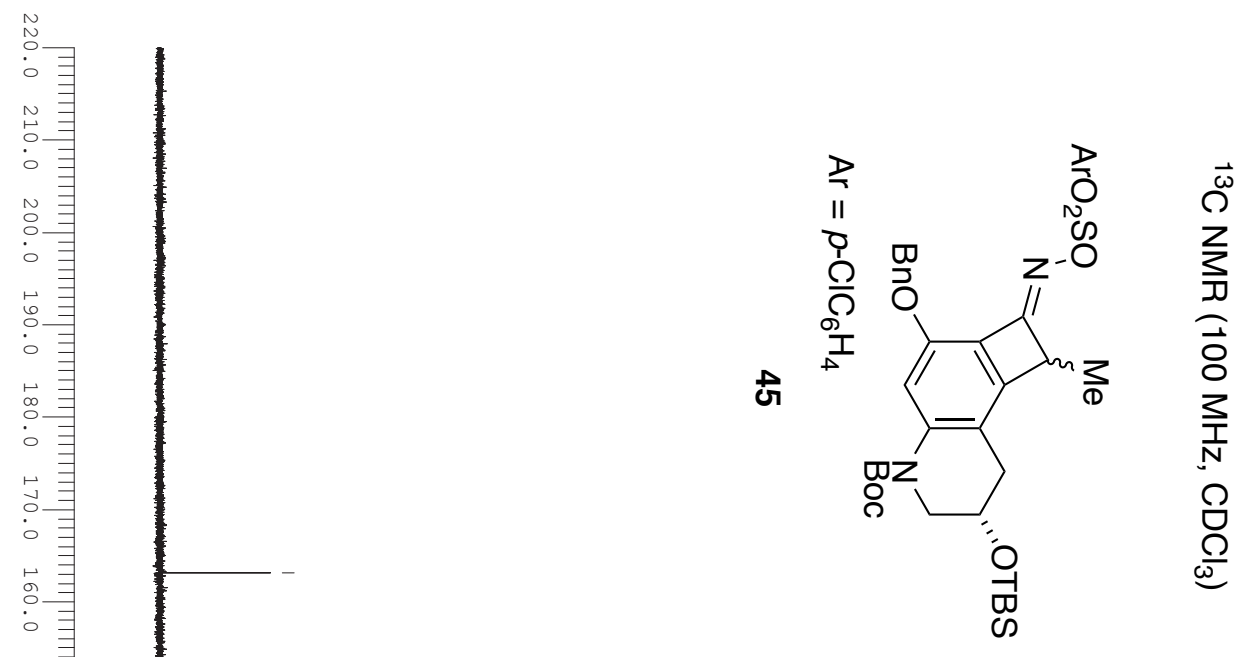

81.808 81.783 77.321 77.000
76.679 72.052 64.602 64.511

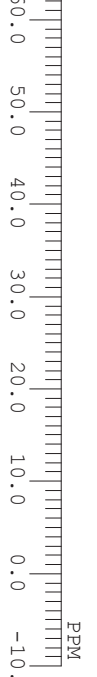

50.515 50.433
47.766

32.478 32.387 28.205 25.776

18.120 15.979 15.897 。 


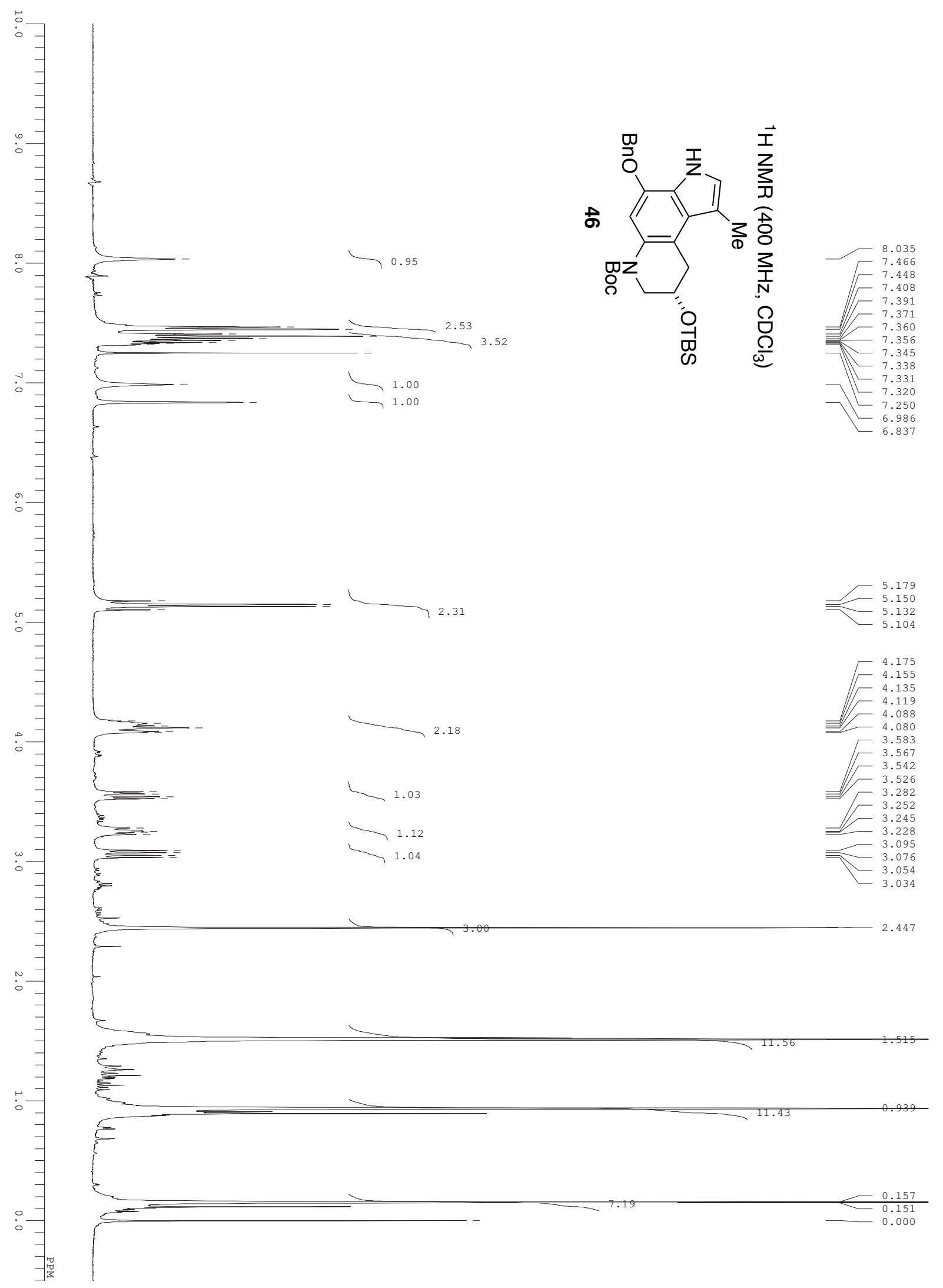




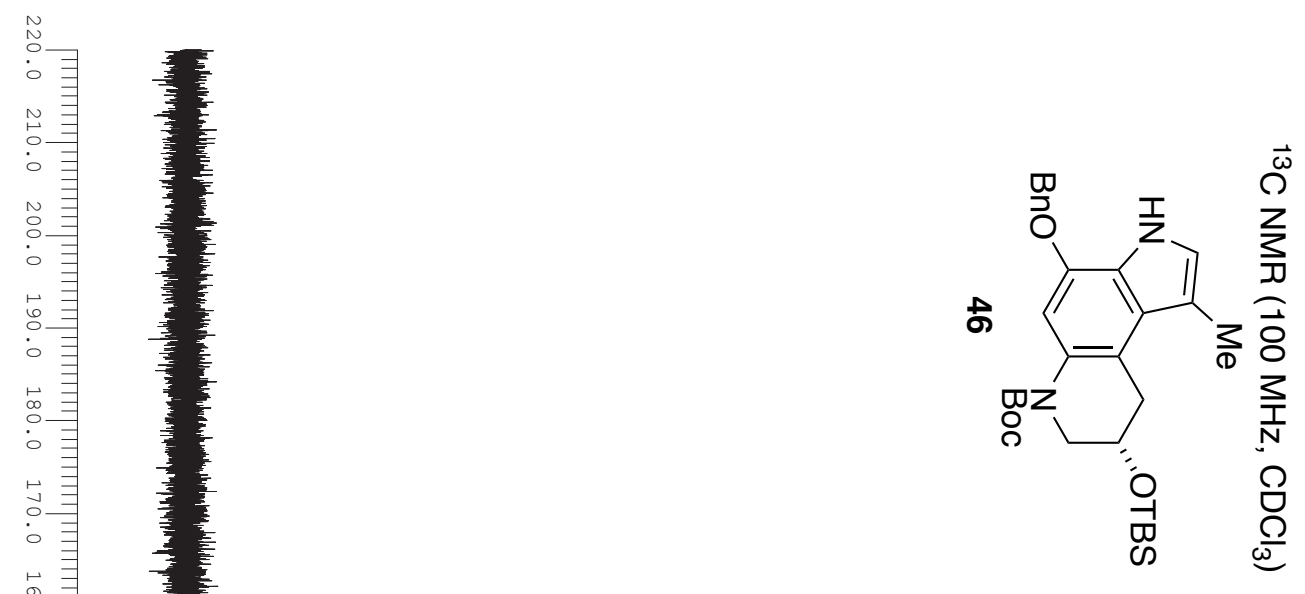

80.293

77.321

77.206

77.000

76.679

66.512

50.532

ज 28.295 25.933 25.858 25.793 18.268 13.015 。

$-4.603$ $-4.718$ 

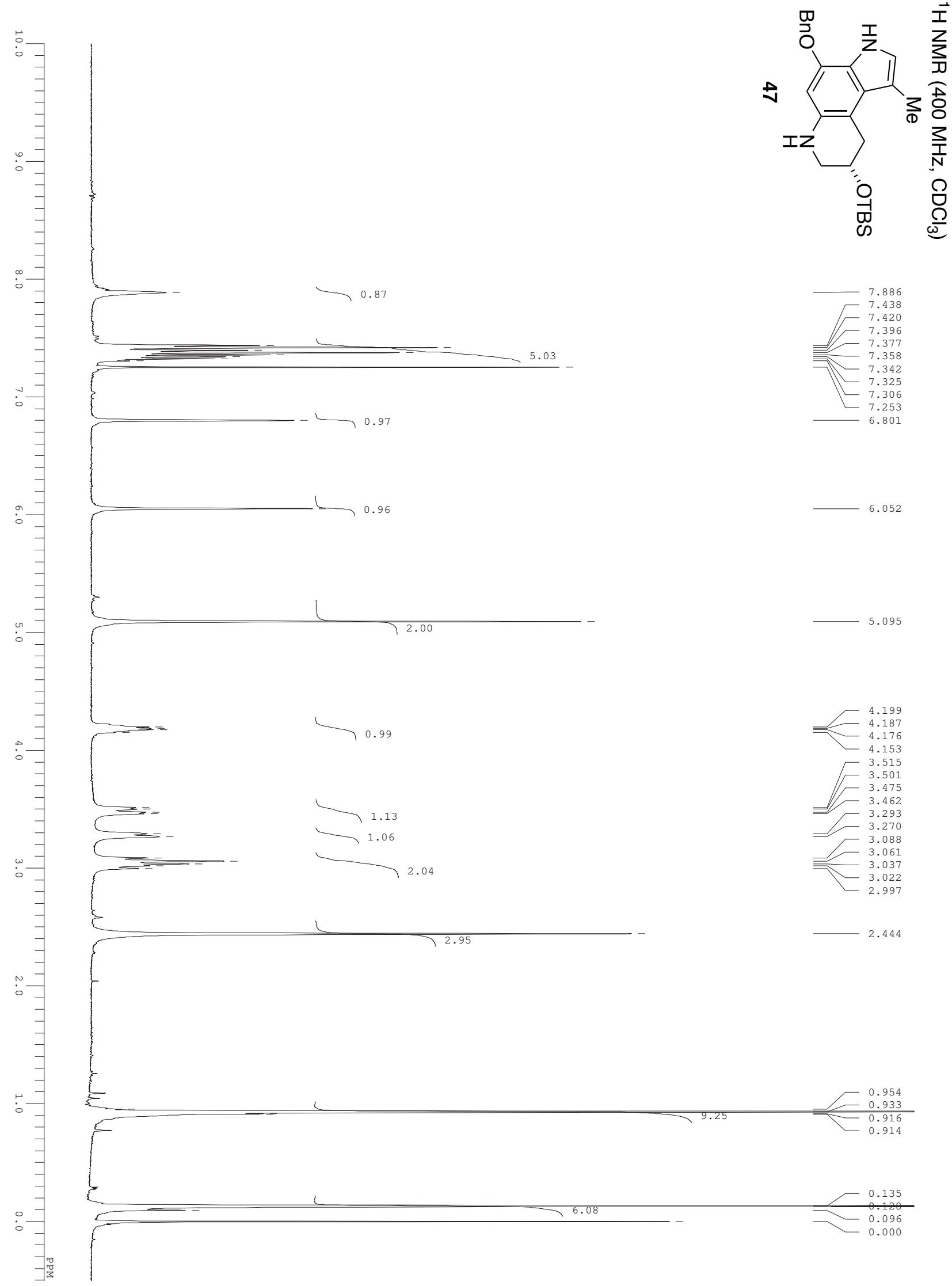


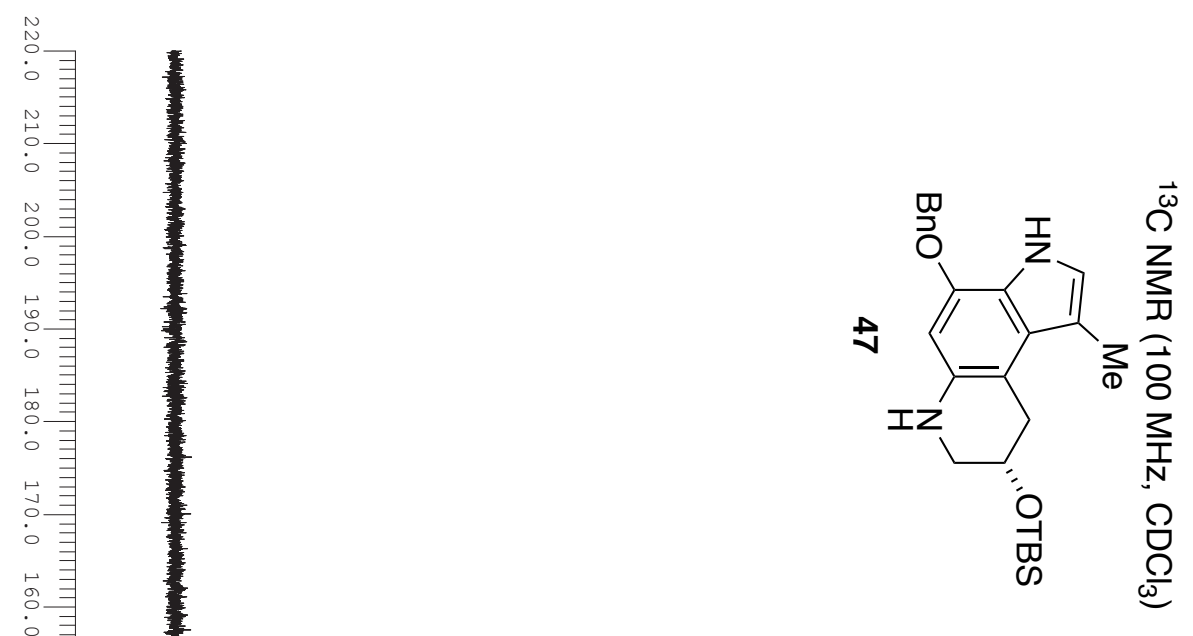

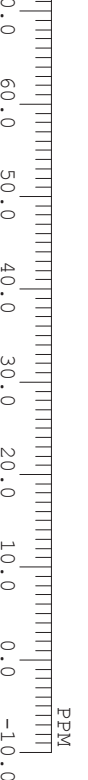

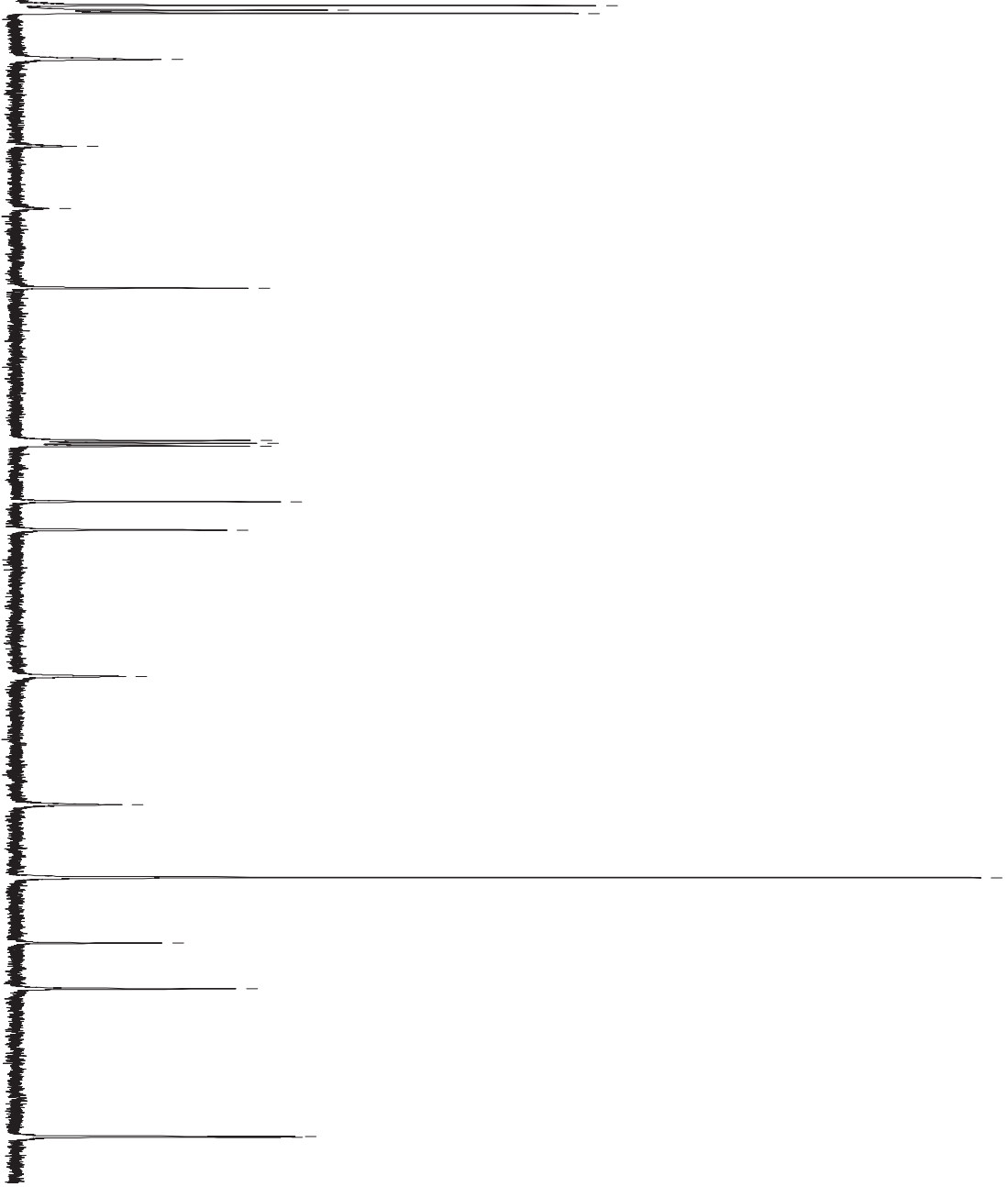

104.596

95.246

77.321

77.000
76.679

70.128

66.795

49.586

34.492

25.916

18. 204

12.822

$-4.544$

$-4.626$ 


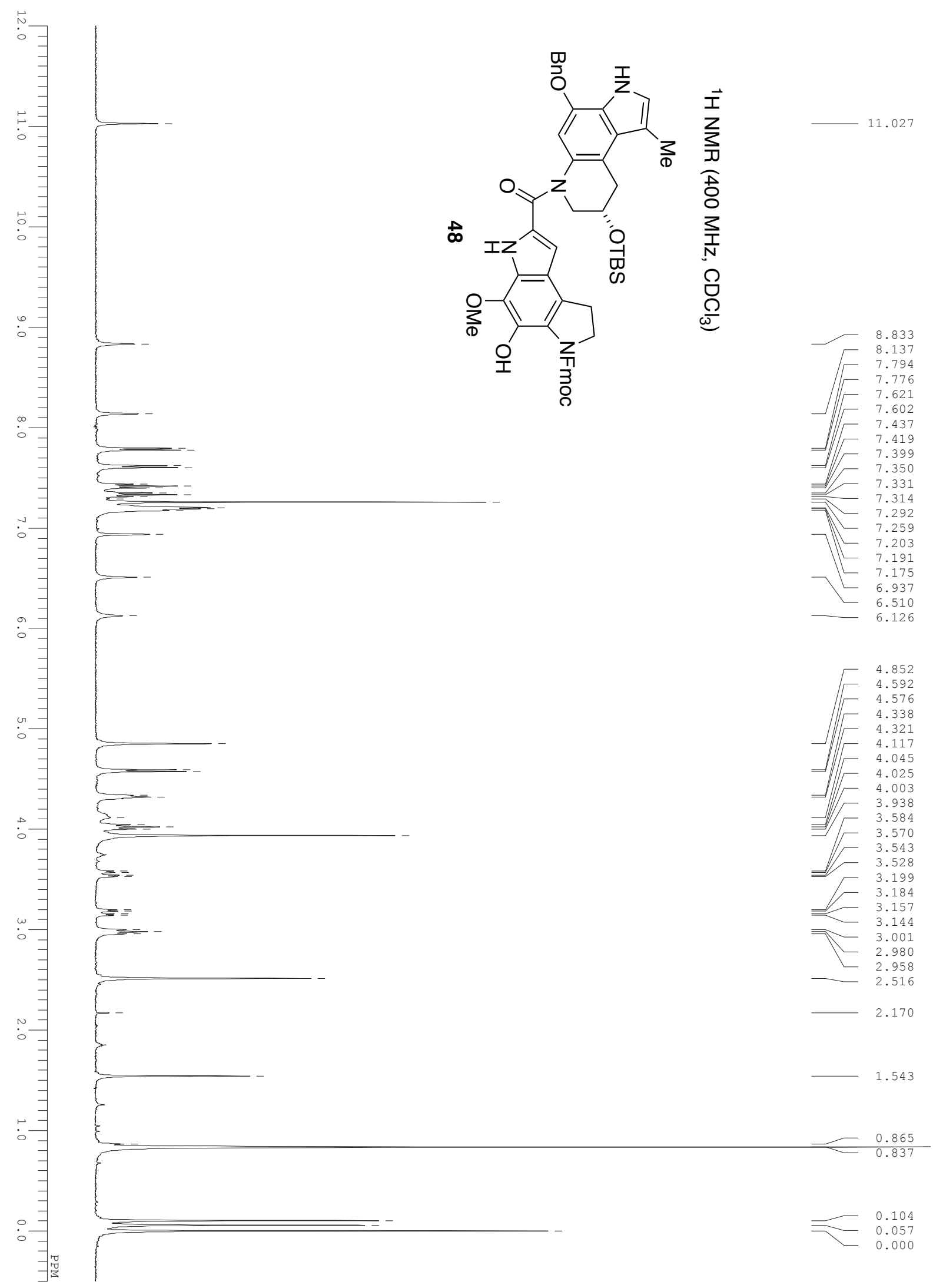




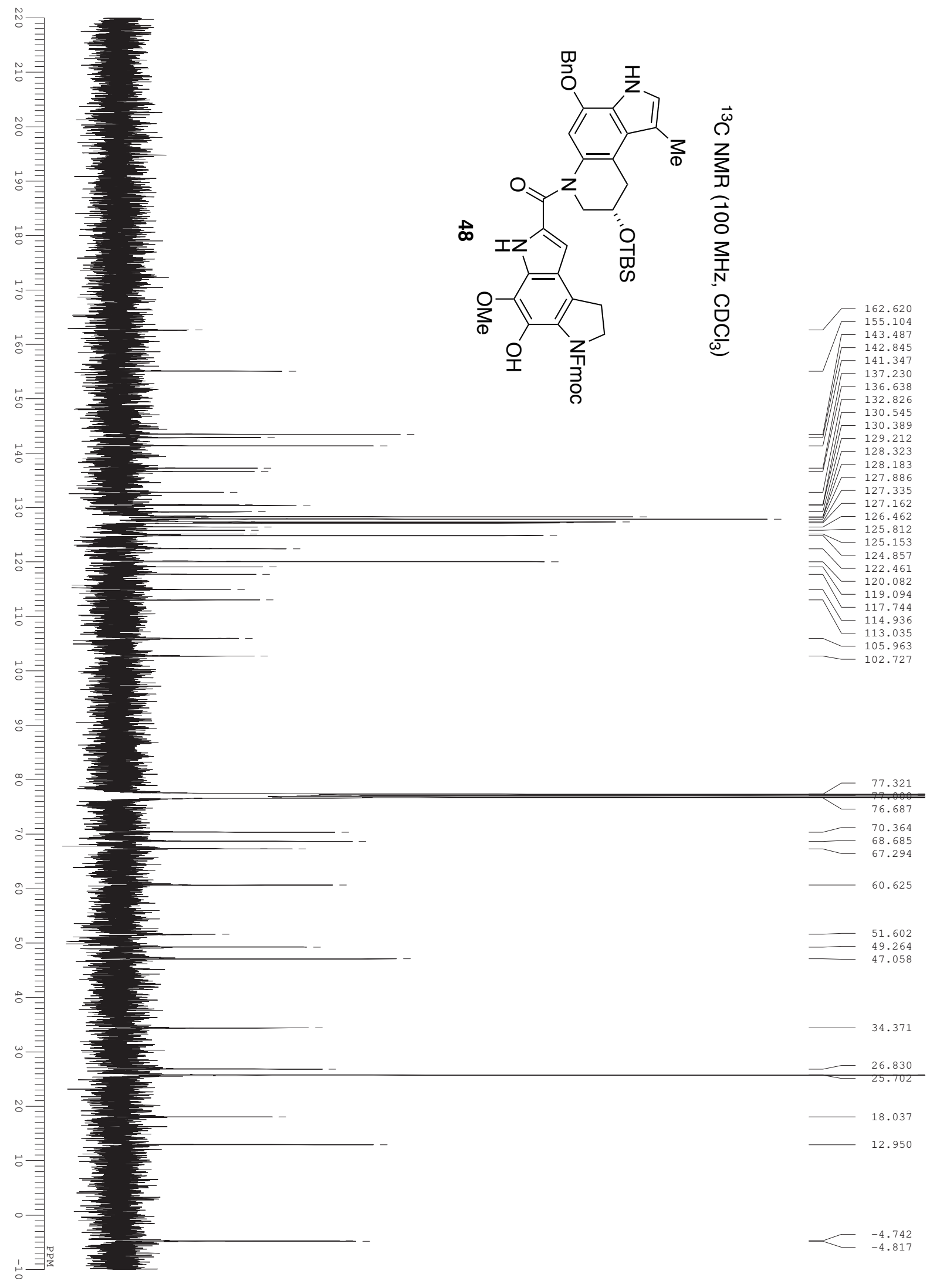




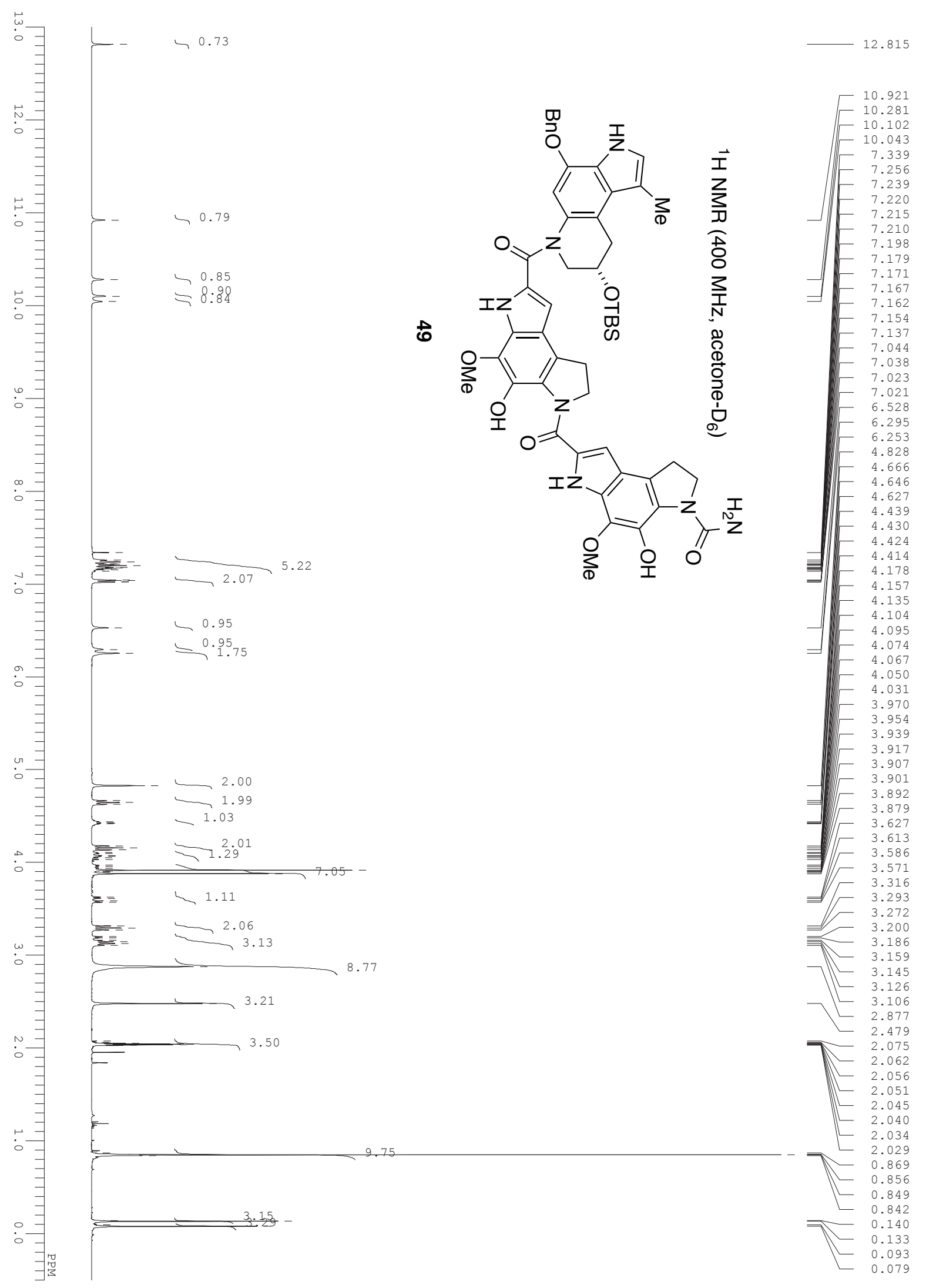




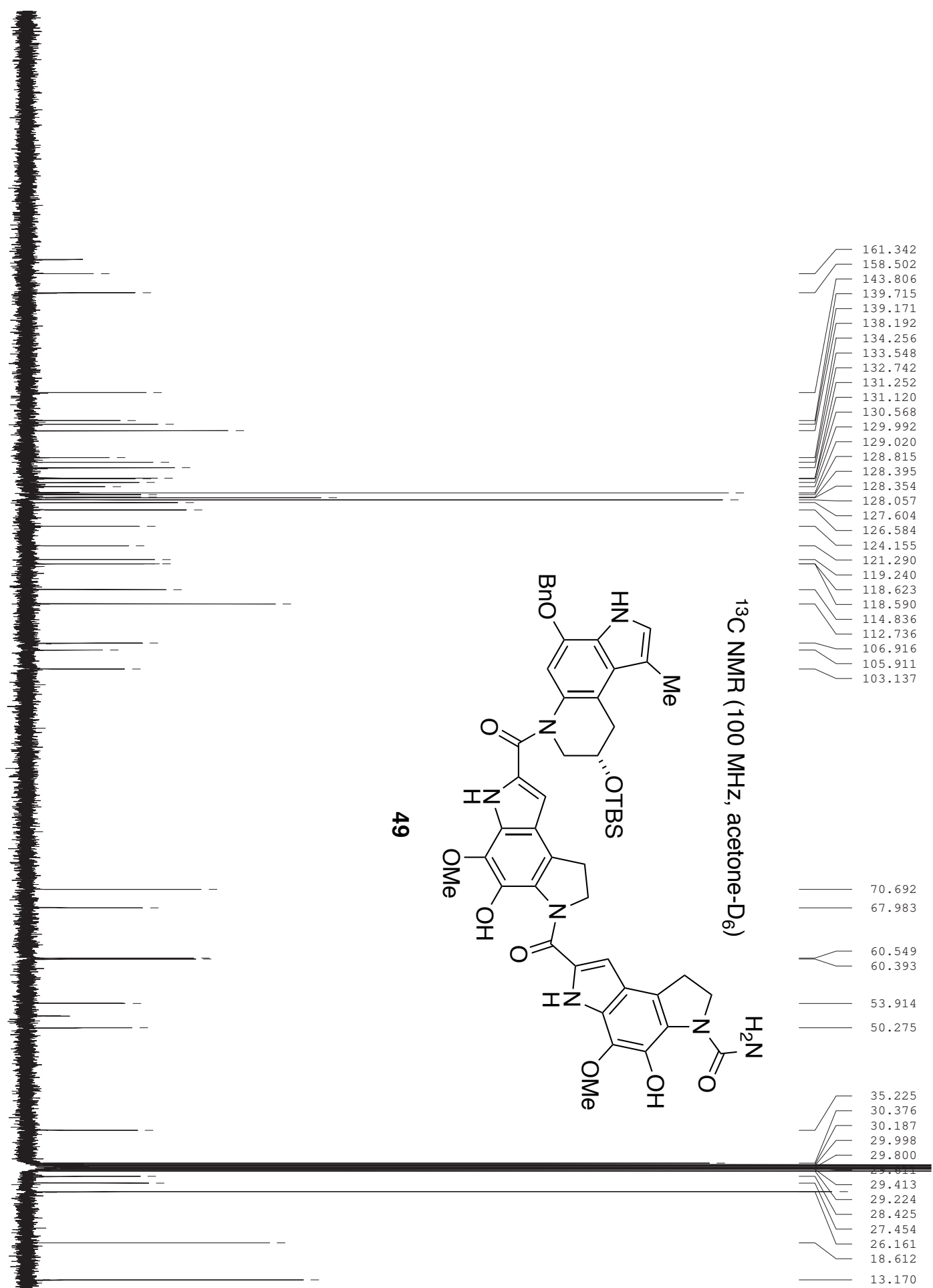




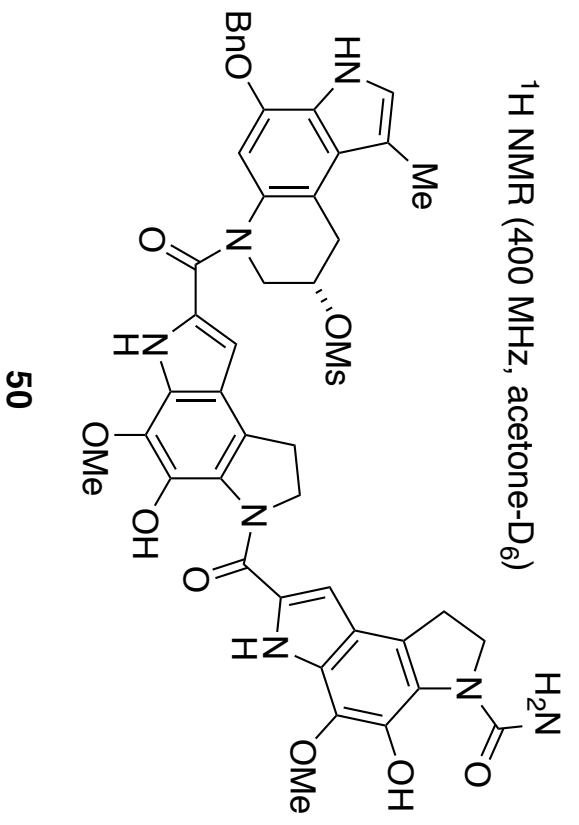




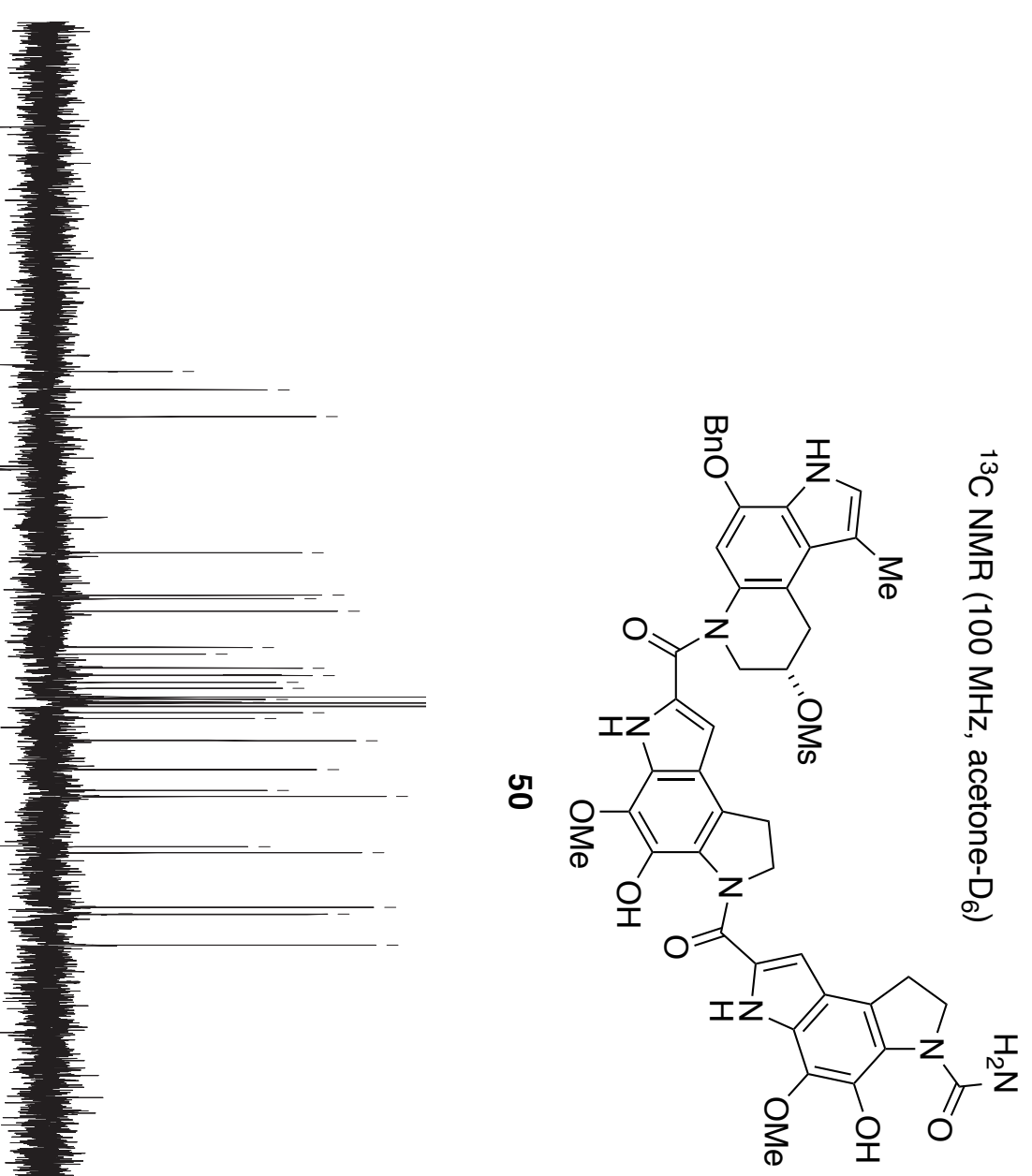

163.285
161.367 158.502 144.202 139.748
139.377 138.076 134.289 133.557
132.116 132.116 130.585 130.585
-129.967 129.037 128.848 128.403 128.066 127.432 126.789
124.476 121.422 119.240 118.598 113.304

112.679
106.949

106.949
106.208 102.980

77.113 70.741

60.574
60.384

53.930 50.291
49.213 43.400 43.400
38.387 31.611 30.376 30.187
29.989 29.611 


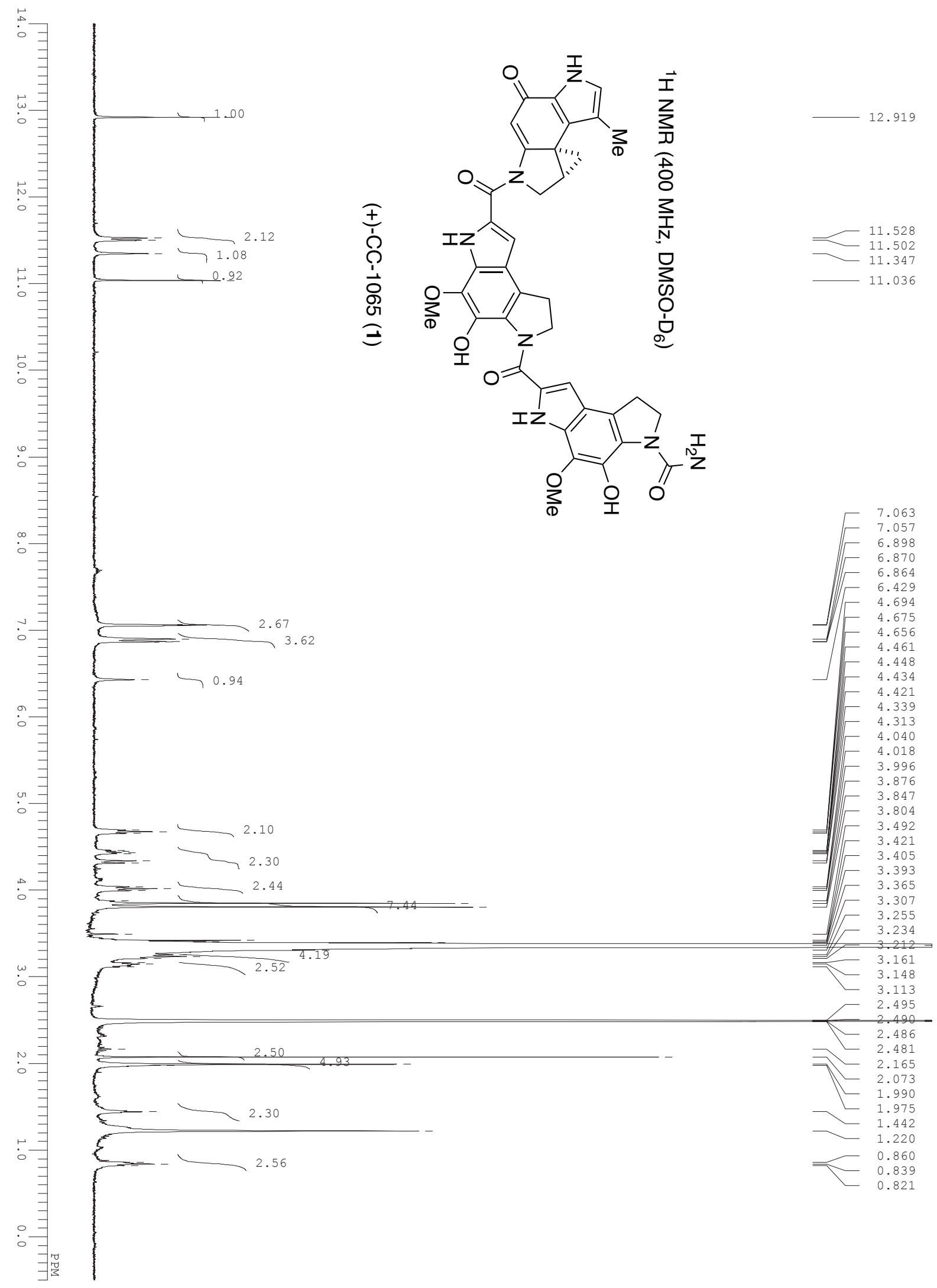




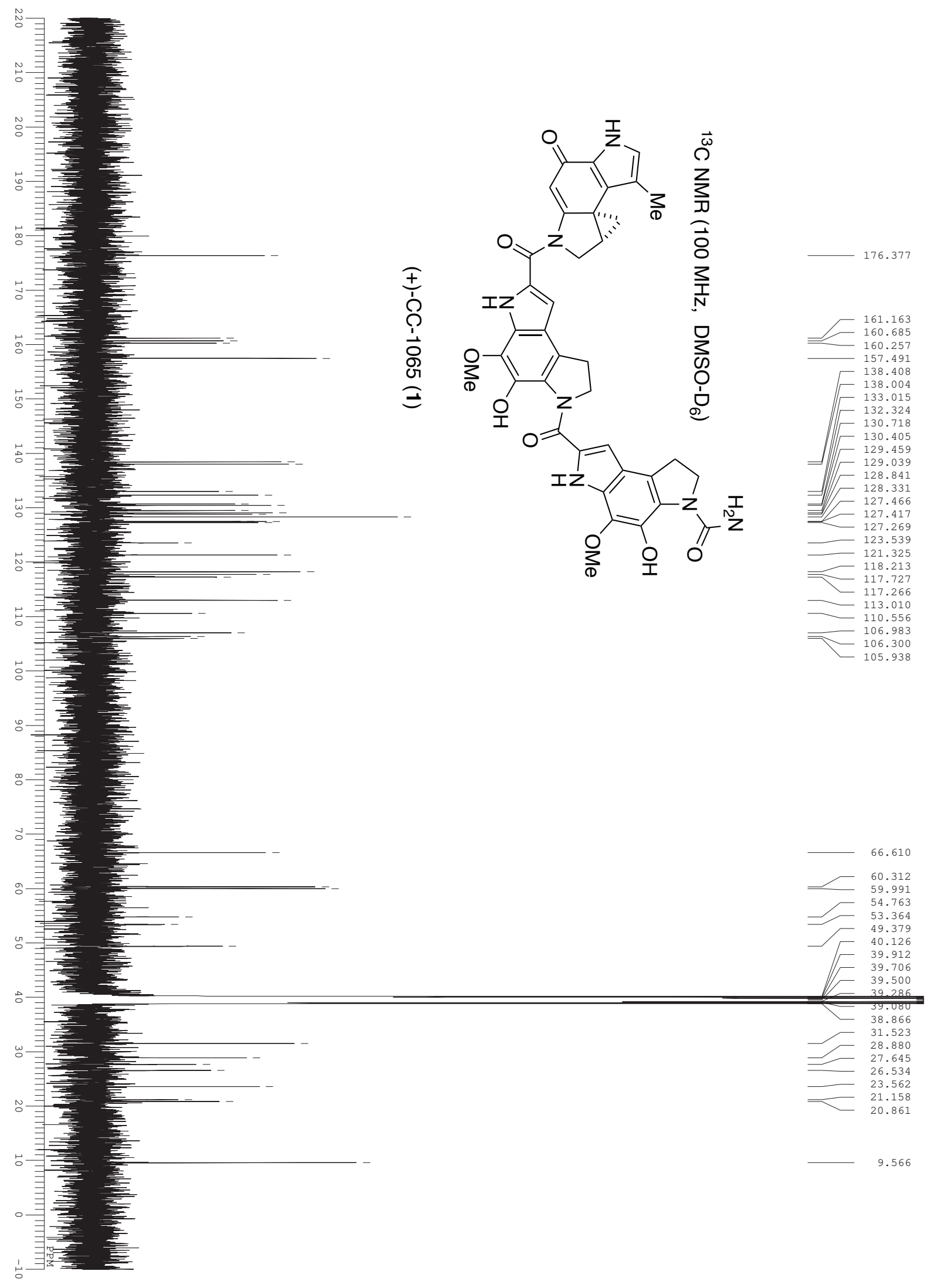

